\title{
Dietary Sulforaphane in Cancer Chemoprevention: The Role of Epigenetic Regulation and HDAC Inhibition
}

\author{
Stephanie M. Tortorella, ${ }^{1-3}$ Simon G. Royce, ${ }^{4,5}$ Paul V. Licciardi, ${ }^{6}$ and Tom C. Karagiannis ${ }^{1,4}$
}

\begin{abstract}
Significance: Sulforaphane, produced by the hydrolytic conversion of glucoraphanin after ingestion of cruciferous vegetables, particularly broccoli and broccoli sprouts, has been extensively studied due to its apparent health-promoting properties in disease and limited toxicity in normal tissue. Recent Studies: Recent identification of a sub-population of tumor cells with stem cell-like self-renewal capacity that may be responsible for relapse, metastasis, and resistance, as a potential target of the dietary compound, may be an important aspect of sulforaphane chemoprevention. Evidence also suggests that sulforaphane may target the epigenetic alterations observed in specific cancers, reversing aberrant changes in gene transcription through mechanisms of histone deacetylase inhibition, global demethylation, and microRNA modulation. Critical Issues: In this review, we discuss the biochemical and biological properties of sulforaphane with a particular emphasis on the anticancer properties of the dietary compound. Sulforaphane possesses the capacity to intervene in multistage carcinogenesis through the modulation and/or regulation of important cellular mechanisms. The inhibition of phase I enzymes that are responsible for the activation of pro-carcinogens, and the induction of phase II enzymes that are critical in mutagen elimination are well-characterized chemopreventive properties. Furthermore, sulforaphane mediates a number of anticancer pathways, including the activation of apoptosis, induction of cell cycle arrest, and inhibition of NF $\kappa$ B. Future Directions: Further characterization of the chemopreventive properties of sulforaphane and its capacity to be selectively toxic to malignant cells are warranted to potentially establish the clinical utility of the dietary compound as an anticancer compound alone, and in combination with clinically relevant therapeutic and management strategies. Antioxid. Redox Signal. 22, 1382-1424.
\end{abstract}

\section{Introduction}

$\mathbf{T}$ HE PROMOTION OF HEALTH by a diet that is rich in Brassica vegetables, including its association with a decreased risk of cardiovascular disease $(52,130,189,276)$ and a lower incidence in a wide variety of cancer types, including breast, lung, prostate, and colorectal cancer, has been extensively reported in the literature $(75,129,205,285$, 288). A diet of three to five servings per week is sufficient to decrease the risk of cancer development by $\sim 30 \%-40 \%$ (122). Table 1 provides a detailed summary of the epidemiological and case-control studies published to date, involving the consumption of cruciferous vegetables and cancer risk. A number of these studies have reported an inverse association with an increase in cruciferous vegetable consumption observed to significantly decrease cancer risk, including malignancies of the breast, lung, prostate, pancreas, and colon $(184,205,255,269,277)$. Systematic reviews of the literature

\footnotetext{
${ }^{1}$ Epigenomic Medicine, Baker IDI Heart and Diabetes Institute, The Alfred Medical Research and Education Precinct, Melbourne, Australia.

${ }^{2}$ Melbourne School of Land and Environment, Department of Agriculture and Food Systems, The University of Melbourne, Parkville, Australia.

${ }^{3}$ Department of Chemical and Biomolecular Engineering, The University of Melbourne, Parkville, Australia.

${ }^{4}$ Department of Pathology, The University of Melbourne, Parkville, Australia.

${ }^{5}$ Department of Pharmacology, Monash University, Clayton, Australia.

${ }^{6}$ Allergy and Immune Disorders, Murdoch Children's Research Institute, Melbourne, Australia.
} 


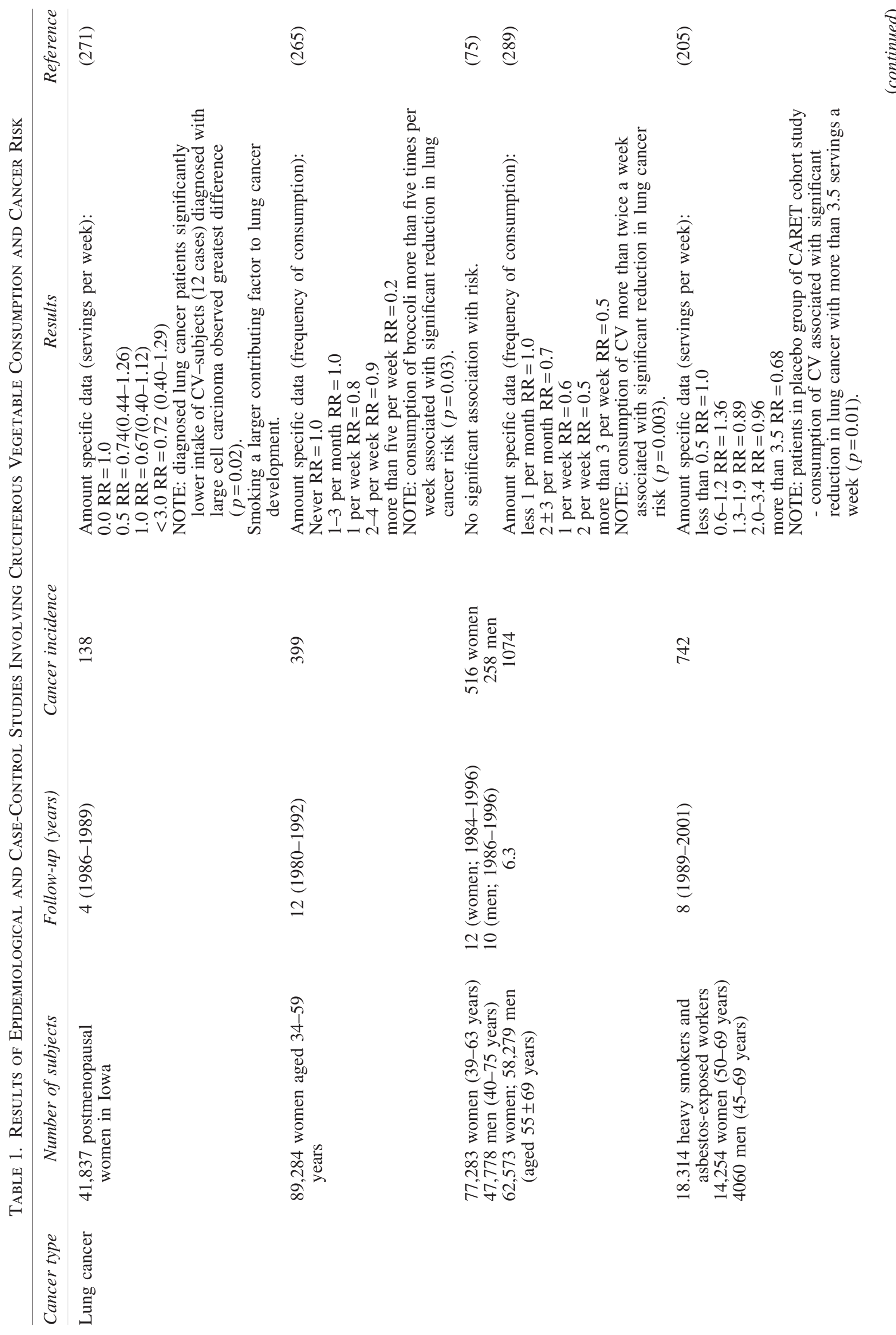




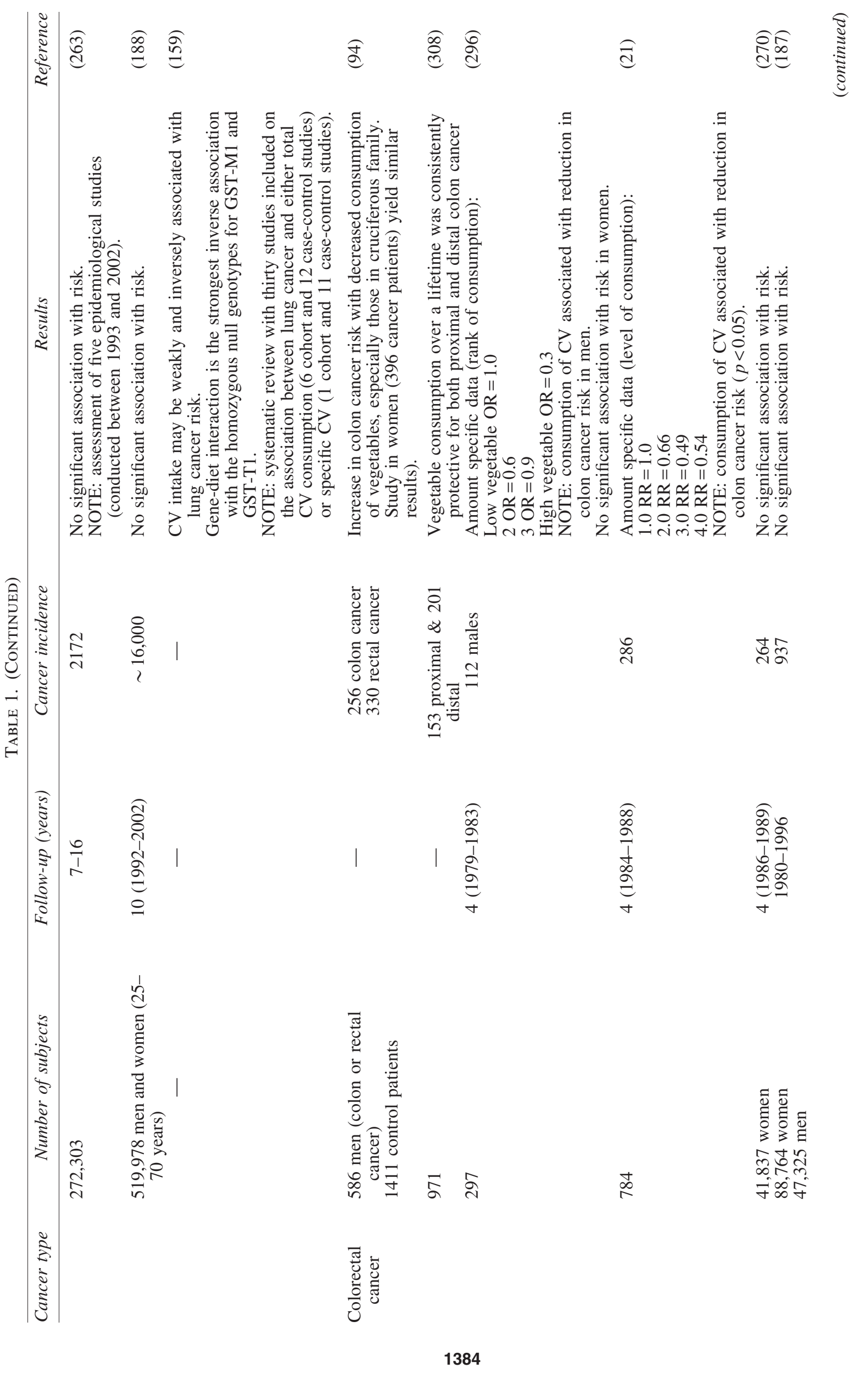




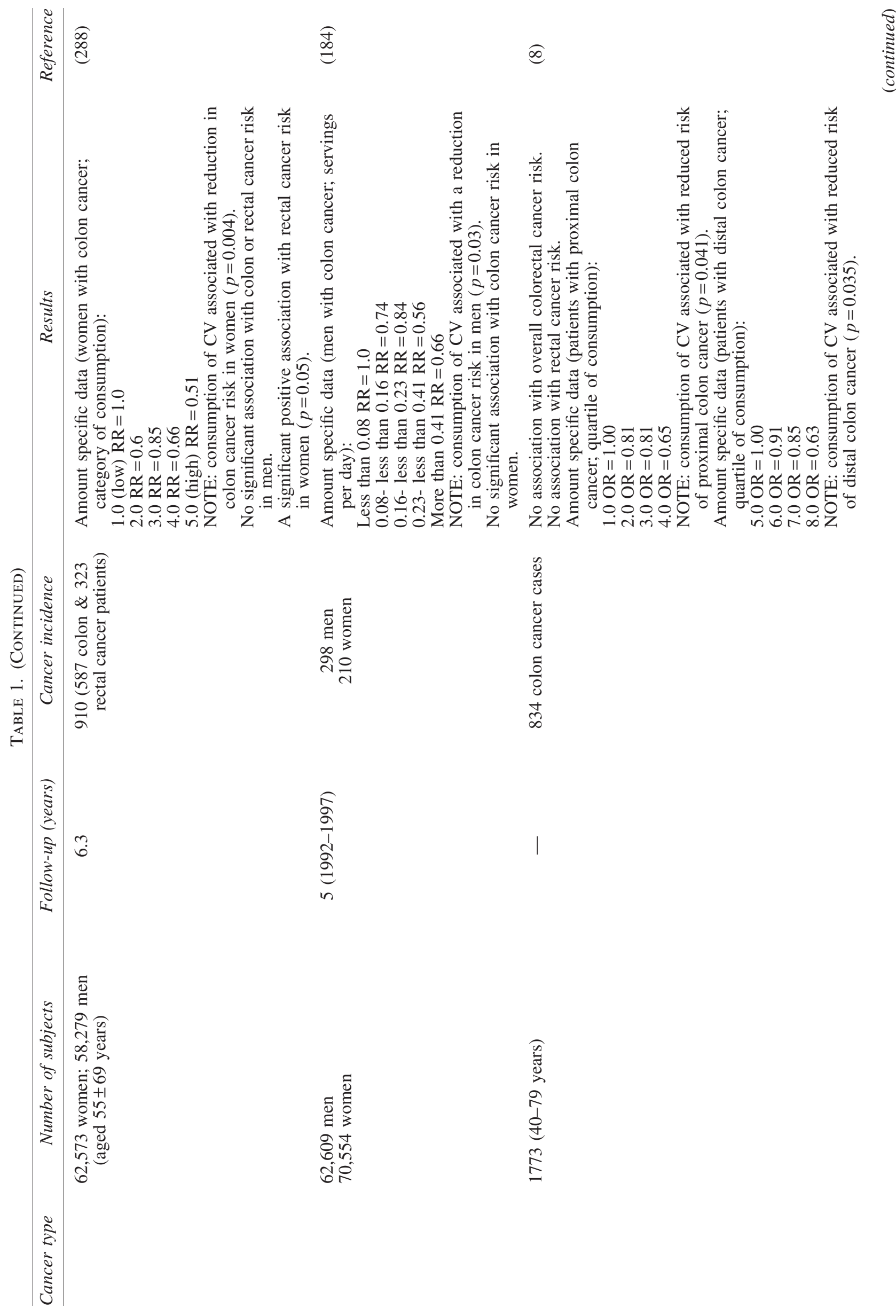




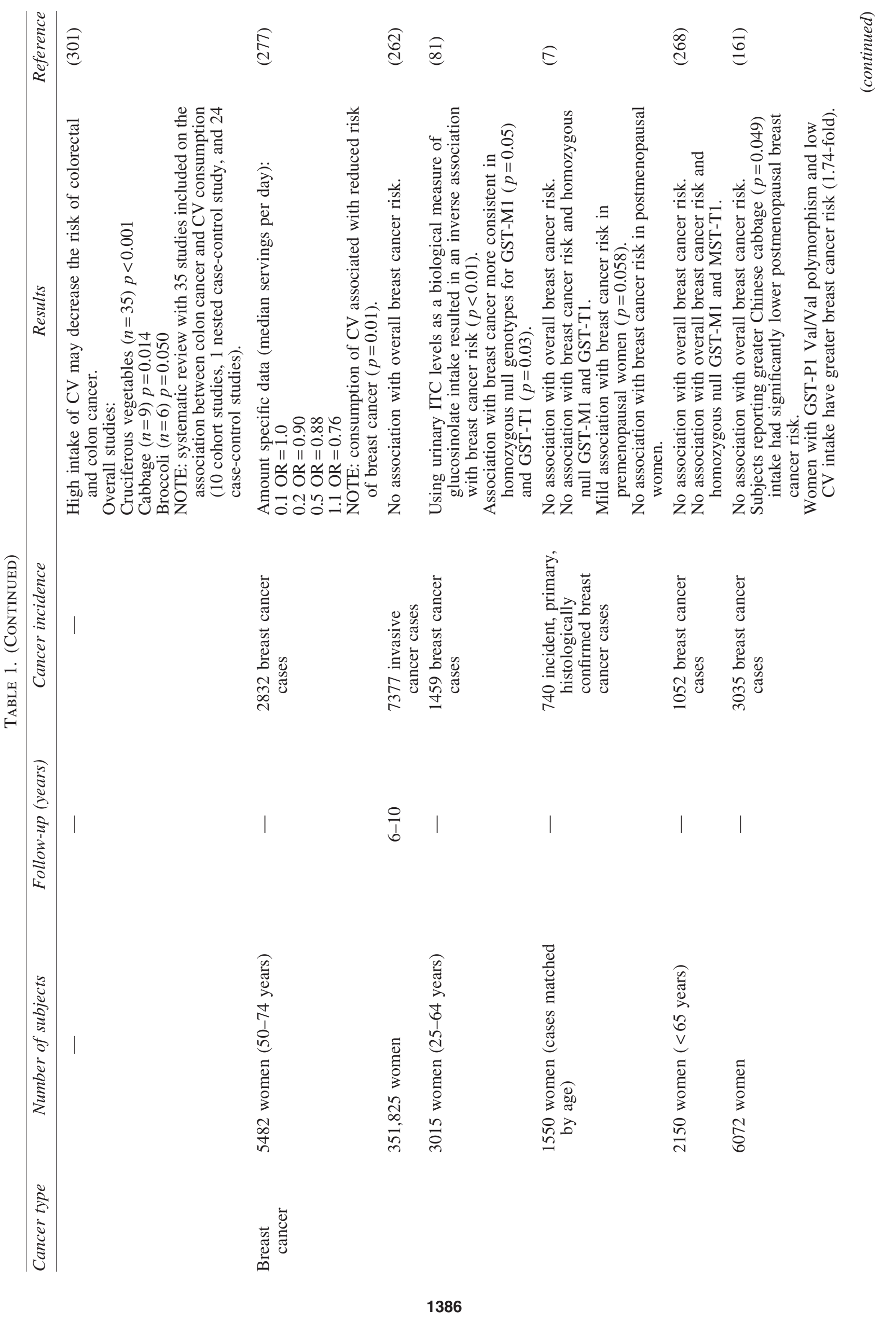




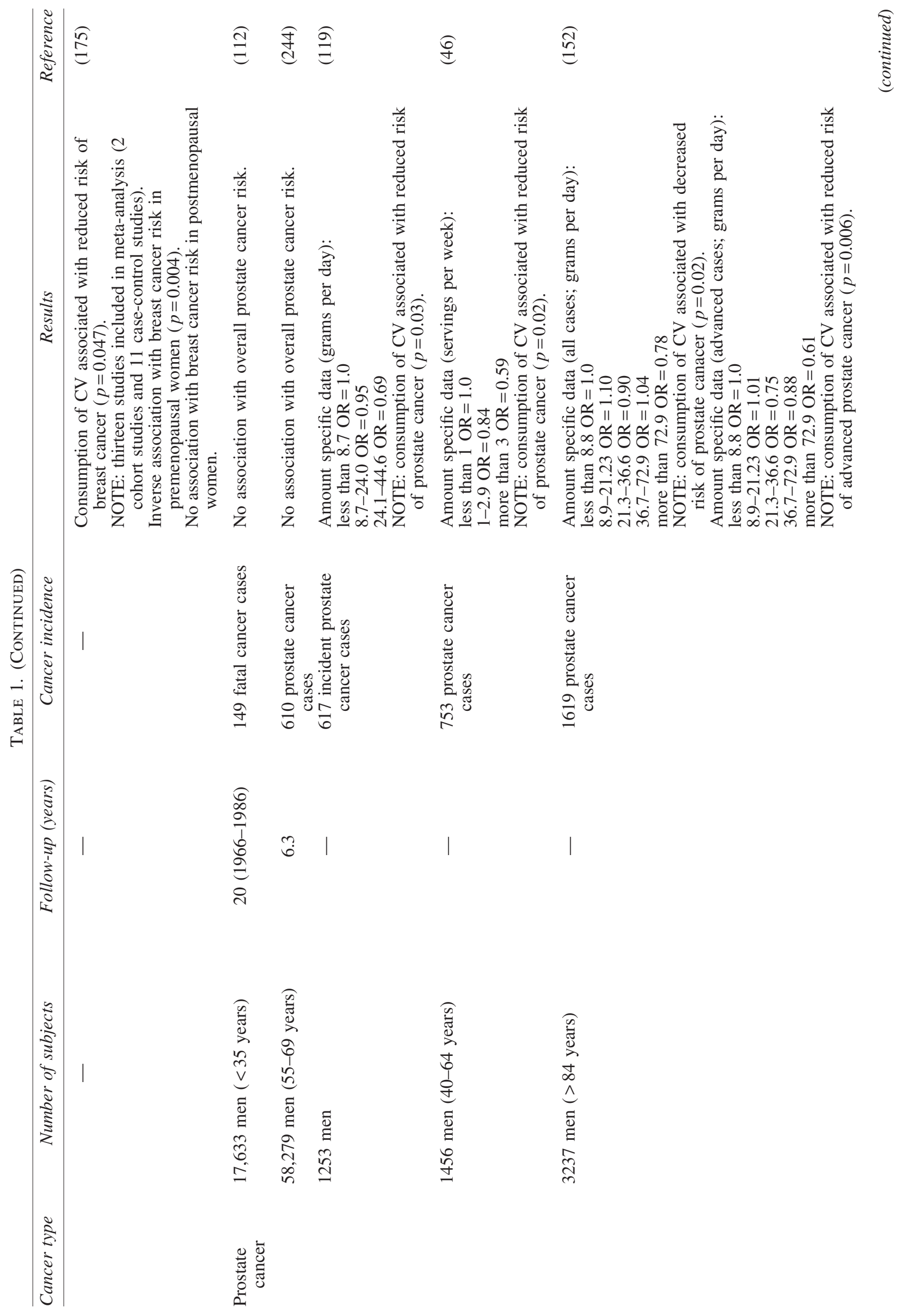




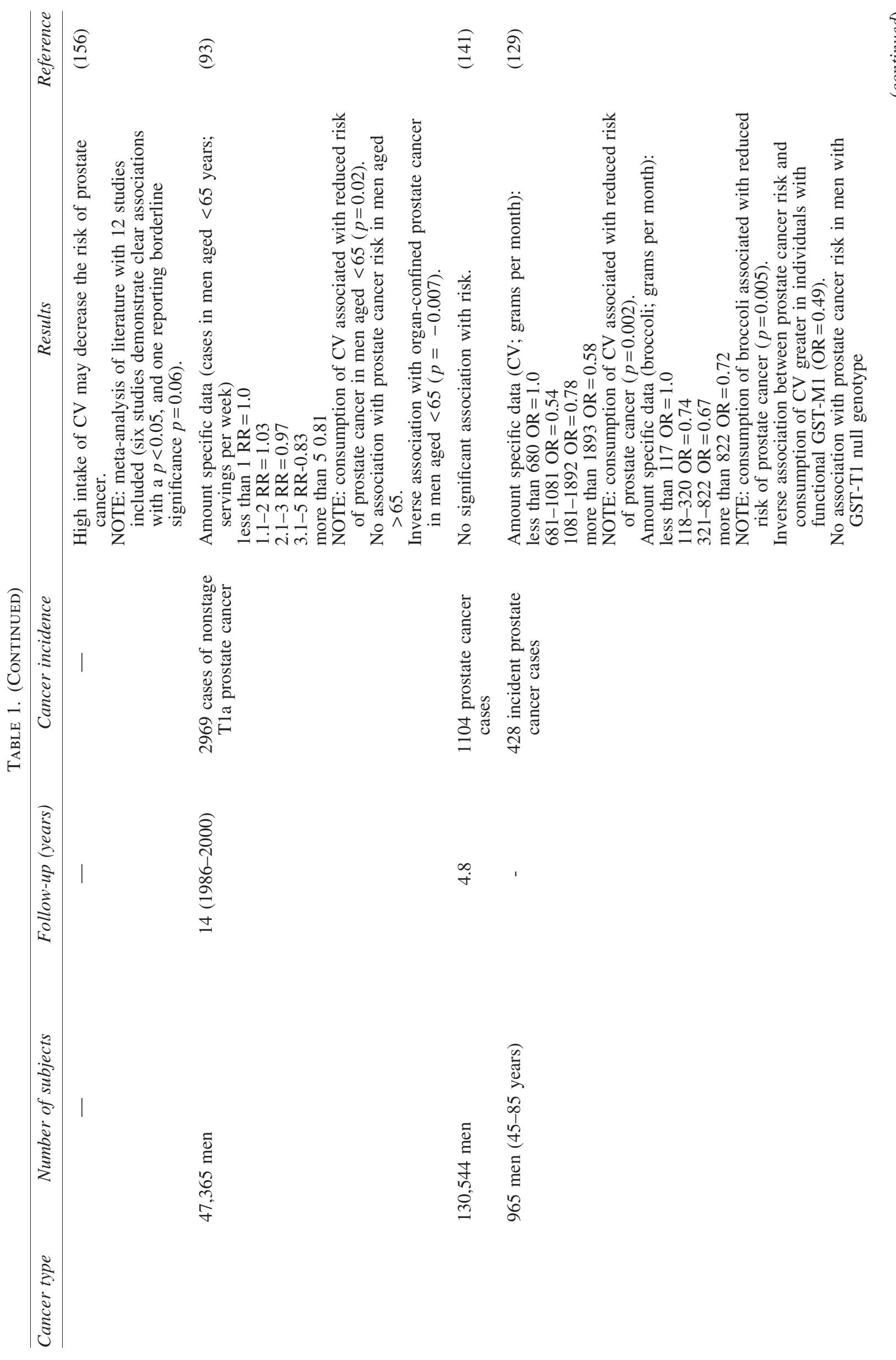




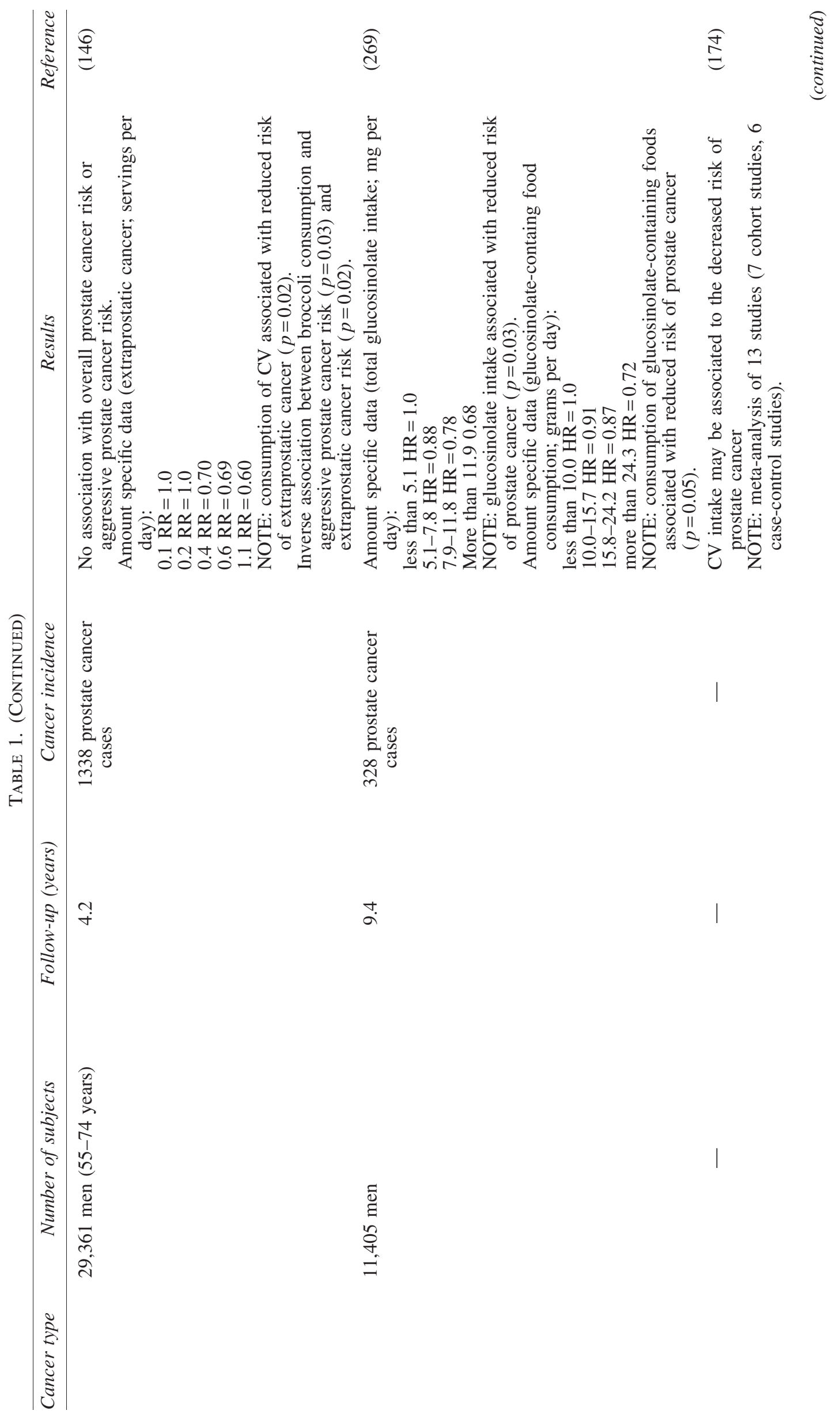




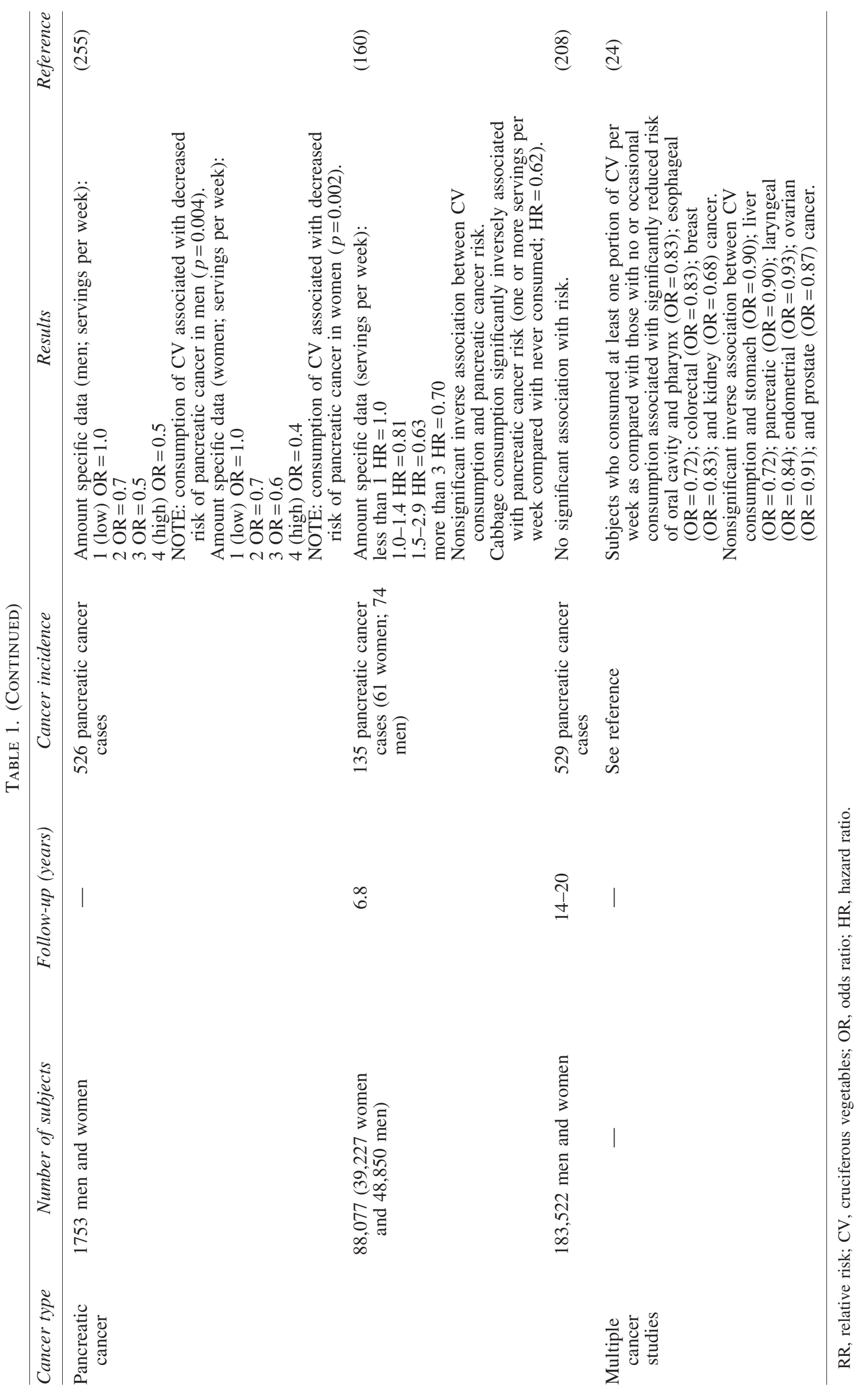


have also confirmed the association, with cruciferous vegetable intake weakly correlated with a decreased risk of cancer development $(159,174,175,301)$. Of note, Bosetti et al. conducted an integrated series of case-control studies on various malignancies in order to assess cancer incidence and cruciferous vegetable consumption (24). It was found that subjects who consumed at least one portion of cruciferous vegetables per week as compared with those with no or occasional consumption were associated with a significantly reduced risk of oral cavity and pharynx, esophageal, colorectal, breast, and kidney cancer. In addition, Brassica vegetables have been associated with the induction of protective mechanisms against pollution-related upper airway inflammation $(231,232)$, as well as a reduction in markers of oxidative stress and hypertension in heart and kidney tissues (300). The elucidation of the biological mechanisms underlying the putative health benefits of cruciferous vegetable consumption has been subject to extensive investigation, with further studies required in order to complete understanding.

\section{Phylogeny, Molecular Genetics, and Biochemistry of Glucosinolate-Containing Plant Species}

Glucosinolates are a class of secondary compounds present in angiosperms of the order Brassicales, which comprises 18 families, 398 genera, and $\sim 4450$ species (100). Figure 1 summarizes the phylogeny of angiosperms, with the Brassicales belonging to the malvids group of the monophyletic clade rosids, in accordance to the Angiosperm Phylogeny Group (APG) III system. The APG III system of flowering plant classification is the third version of a molecular-based plant taxonomy system published in 2009 by the APG (278). Overall, Brassicales contain $\sim 2.2 \%$ of the eudicot diversity, with their earliest fossil known from the Turonian (89.5 millions years ago) (180). The most important, and perhaps most extensively studied glucosinolate-producing family is the Brassicaceae, which comprises 49 tribes, including the tribes Brassiceae and Arabideae (190). Plants belonging to the Brassicaceae family exhibit species-specific profiles of
FIG. 1. The phylogeny of angiosperms (flowering plants) in accordance to the Angiosperm Phylogeny Group (APG) III system. The order Brassicales includes all glucosinolate-producing plants, including those in the Brassiceae (cruciferous vegetable) and Arabideae tribes.

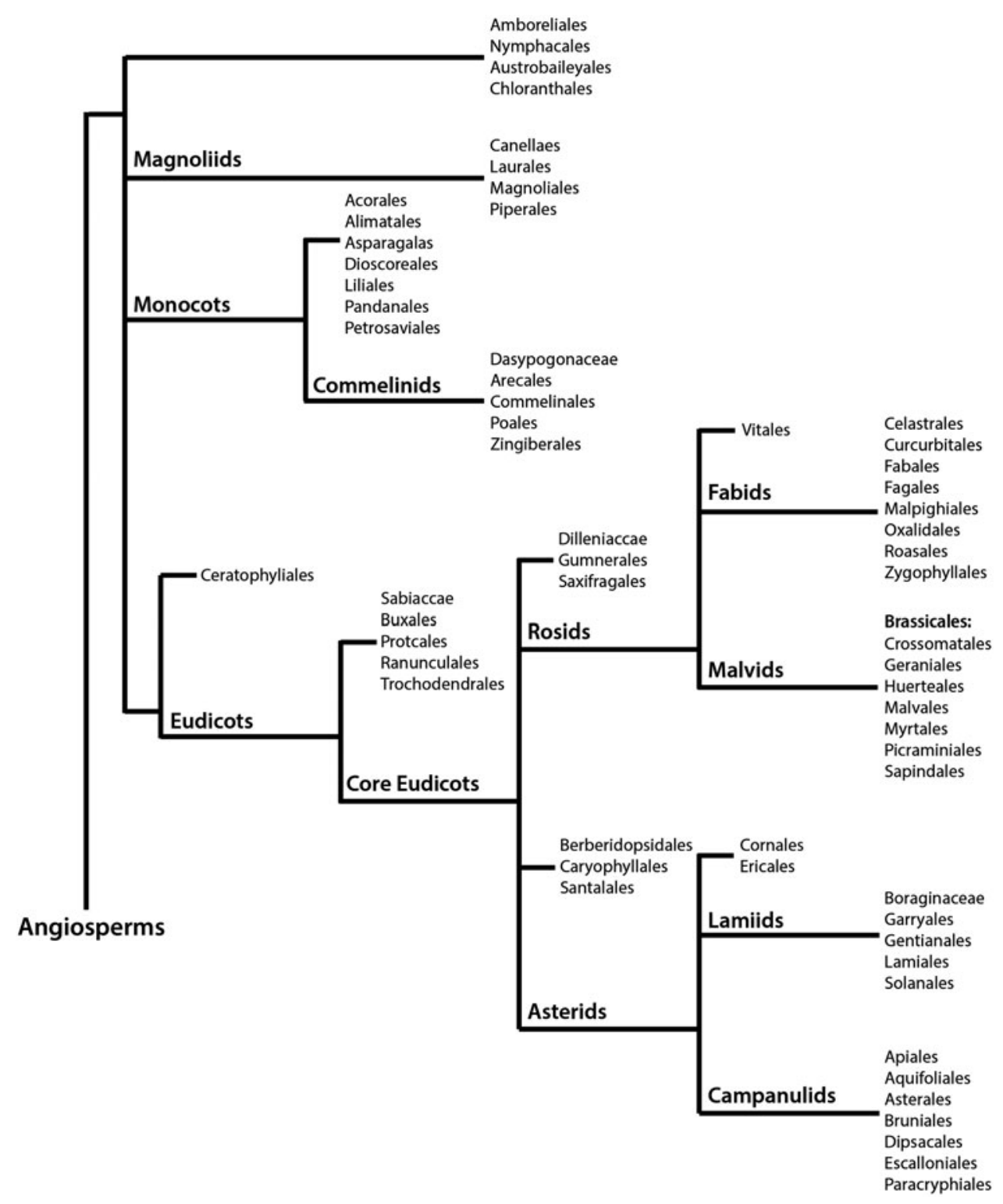


glucosinolates, a class of compounds thought to function as a part of a defence mechanism against pathogens and insects (9). Difficulty in establishing evolutionary trends and utilizing morphology in phylogenetic studies has been a challenge due to homoplasy in the family $(6,281)$. The first comprehensive phylogenetic study by Beilstein et al. used a sample of 101 genera within the family to assess the chloroplast gene $n d h F$ for an intergeneric relationship (19). This study placed the genera into clades (recognized as tribes) grouped into three main lineages (I-III). Currently, lineage I include 15 tribes, lineage II has been expanded to include 25 tribes, and lineage III now comprises seven tribes $(82,88,295)$. Substantial support for this system has been provided using an internal transcribed spacer of nuclear ribosomal DNA (ITS)based phylogeny, nuclear alcohol dehydrogenase, chalcone synthase, and plastidic maturase sequence data $(14,150)$. The tribes Brassiceae and Arabideae are a part of lineage II, with floral monosymmetry evolved independently several times within this lineage (27).

Advances in the understanding of glucosinolate biosynthesis through studies in Arabidopsis thaliana and Brassica sp. have suggested that aliphatic glucosinolates (including glucoraphanin) are derived from methionine, tryptophan, and phenylalanine (191, 192). A comparison between Brassica oleracea L. var. italic, possessing a Brassica C.genome, and Arabidopsis genomes showed sequence similarity and gene order and content colinearity in specific chromosomal segments (222). The synthesis of glucosinolates is determined by a simple genetic system containing two distinct sets of genes, one determining sidechain elongation and the second involved in the chemical modification of the sidechains (Fig. 2A).

Many of the glucosinolates found in Brassica vegetables are derived from chain elongated forms of methionine or phenylalanine (286). Figure $2 \mathrm{~B}$ provides a genetic model of methionine-derived glucosinolate biosynthesis, with the total level and nature of the glucosinolate determined early in the process, and the initial entry of methionine into the pathway catalyzed by methylthioalkylmalate (MAM) synthase genes at the GS-ELONG loci $(58,76)$. MAM synthases catalyze the condensation of acetyl CoA as the methyl donor, with an $\alpha$ keto acid derived by amino-acid transanimation to result in elongated methionine. Different members of this family may catalyze different number of rounds of elongation, with genetic variation at the GS-ELONG and GS-PRO loci enabling selection for different glucosinolate profiles, while allelic variation at the quantitative trait loci determines overall amount (286). These initiating factors have been observed in both Arabidopsis and Brassica $(58,242)$. In B. oleracea, these genes determine the length of the side chain with either one or two rounds of methionine elongation to produce $3 \mathrm{C}$ or 4C glucosinolates, respectively (242). Li and Quiros demonstrated that glucosinolate synthesis was independently regulated by genes GSL-PRO which determines the synthesis of $3 \mathrm{C}$ glucosinolates, and GSL-ELONG which determines synthesis of 4C glucosinolates (164). Furthermore, MAM and a homologue protein of Arabidposis AOP2 were confirmed to be useful markers for breeding of high glucoraphanin varieties of B. oleracea. Importantly, it was shown that the glucosinolate biosynthesis pathway may be manipulated toward the synthesis of glucoraphanin (precursor to sulforaphane) by increasing the expression level of GSL-ELONG and reducing expression of GSL-PRO. Studies in A. thaliana showed that the overexpression of R2R3-MYB transcription factors (known regulators of glucosinolate biosynthesis), including AtMYB28, AtMYB29, and/or AtMYB76, resulted in the upregulation of the glucosinolate biosynthetic genes and an increase in selected classes of glucosinolates (90, 91, 109, 264). Although genes involved in the regulation of glucosinolate biosynthesis have not yet been functionally identified in Brassica species, Araki et al. suggest that gene homologues of AtMYB28 and AtMYB29 are important in B. oleracea $(9)$.

After biosynthesis, methionine-derived glucosinolates may undergo a number of side chain modifications, including hydroxylation, methoxylation, oxidation, desaturation, conjugation with benzoic acid, and glucosylation (286). For example, methylthioalkyl glucosinolates may be converted to methylsulphinylalkyl glucosinolates by flavin monoxygenases at the GLS-OX loci (99). In turn, these glucosinolates may be modified by 2-oxogluturate-dependent dioxygenases at the GLS-ALK loci and by an unknown enzyme at the GLS-OH loci to form alkenyl and hydroxyl-alkenylglucosinolates, respectively (98). Due to the considerable variation at these loci in $B$. oleracea, selection for specific glucosinolate profiles may be possible with the genetic background being a major factor in determining glucoraphanin concentration and composition (Table 2). Brown et al. concluded that the percentage of glucosinolate variability in broccoli was attributable to genotype for individual compounds, including $54.2 \%$ for glucoraphanin (25). High glucosinolate varieties of broccoli have been specifically bred to accumulate levels that are significantly higher than regular broccoli (242). The best example of deliberate breeding of such broccoli was achieved by crossing a standard cultivar with B.villosa, a wild form of B. oleracea from Sicily, which accumulates high levels of 3-methylthiopropyl glucosinolate (85). This high glucosinolate variety of broccoli was shown to deliver about four times the amount of sulforaphane to the systemic circulation than standard cultivars, with sulforaphane metabolites consumed by GSTM1-positive subjects measured to be $107.5 \mu M$ after consumption of regular broccoli compared with $345.8 \mu M$ in subjects within the group who consumed the high-glucosinolate variety.

\section{Pharmacokinetics and Bioavailability of Dietary Sulforaphane}

The significant accumulation of the glucosinolate, glucoraphanin [4-methylsulfinylbutyl glucosinolate] in broccoli has been shown to be important as the precursor of the bioactive isothiocyanate, sulforaphane (Fig. 3). It is rapidly absorbed, metabolized, and excreted, with $\sim 80 \%$ appearing in the urine within 12-24 h after consumption and/or administration (54). There are many factors that may affect the bioavailability, and therefore overall therapeutic benefit, of dietary sulforaphane, including pharmacokinetic properties, genetic variation, and food preparation (42). Hydrolytic conversion of glucoraphanin to sulforaphane through the action of physical damage to the plant occurs either by the action of plant-derived myrosinase (intracellular broccoli thioglucosidase) (70) or by the microbiota of the human colon $(48,251,252)$. Approximately, $60 \%-80 \%$ of glucoraphanin is converted to sulforaphane (131), with most broccoli varieties possessing between 0.1 and $30 \mu \mathrm{mol} / \mathrm{g}$ of glucoraphanin (Table 2). After rapid diffusion into the cells of the intestinal epithelium due to 


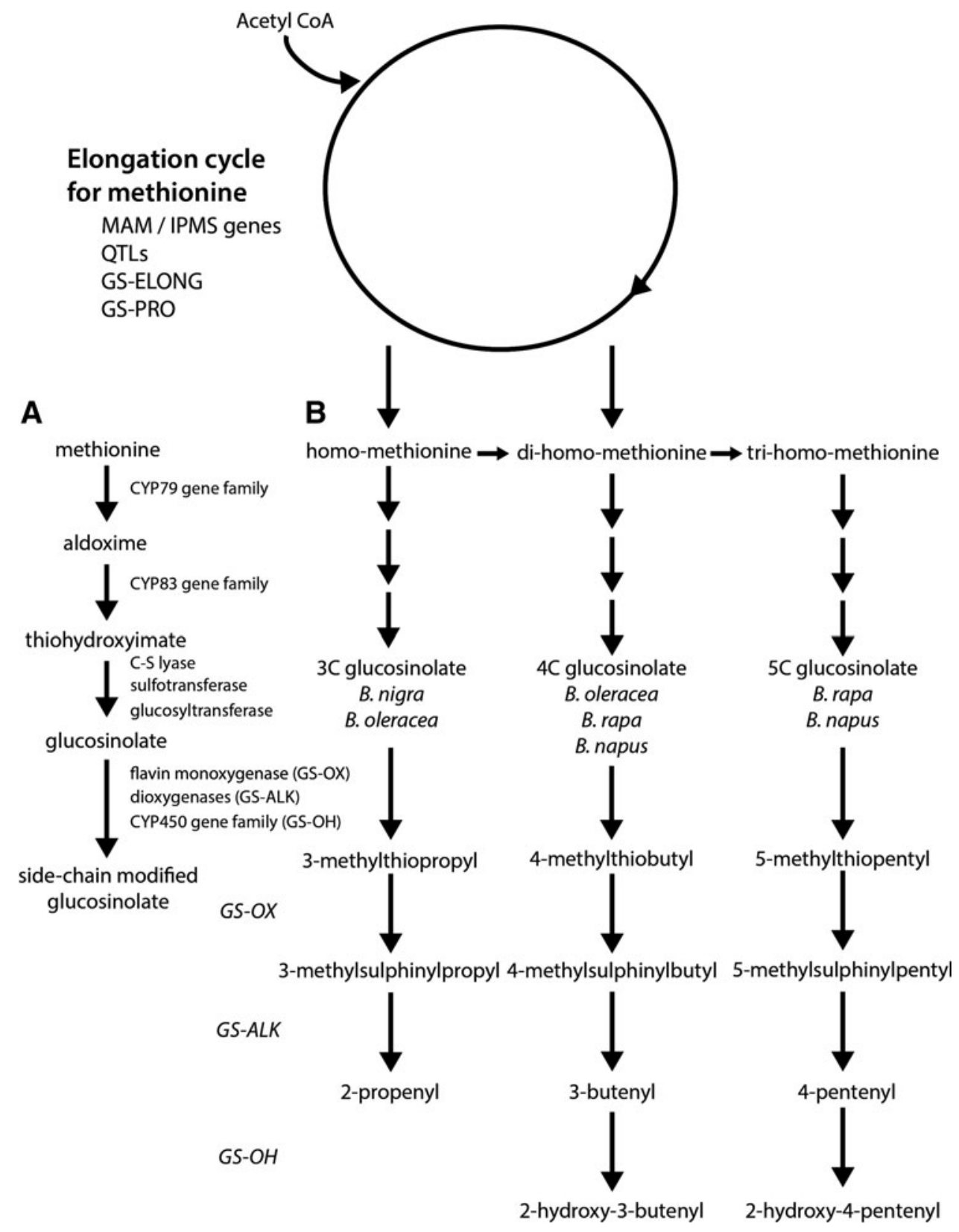

FIG. 2. Genetic model of the glucosinolate biosynthetic pathway in Brassicales. (A) A simple genetic system for the production of glucosinolates from methionine. The initial step involves the conversion of methionine to an aldoxime through the activity of gene products of the CYP79 gene family. The aldoxime undergoes conjugation with cysteine, which acts as a sulfur donor, and is then cleaved by a C-S lyase. Glucosinolate products are subsequently formed through detoxification of potentially toxic thiohydroximates by glucosyltransferase-driven glucosylation, and sulfation by sulphotransferase. Side chain modifications occur with a high frequency, and profiles become particularly complex after elongation of amino acids that are dependent on genetic variation. (B) Genetic model of methionine-derived glucosinolate biosynthesis. Total level and nature of the glucosinolate is determined early in the process, and the initial entry of methionine into the pathway is catalyzed by methylthioalkylmalate (MAM) synthase genes at the GS-ELONG loci. MAM synthases catalyze the condensation of acetyl CoA to result in elongated methionine. Different members of this family may catalyze different number of rounds of elongation, with genetic variation at the GS-ELONG and GS-PRO loci enabling selection for different glucosinolate profiles, while allelic variation at the quantitative trait loci (QTL) determines overall amount.

its lipophilic nature and low molecular weight, sulforaphane undergoes metabolism via the mercapturic acid pathway (218). This process involves its initial conjugation with glutathione, rapidly catalyzed by important glutathione S-transferase (GST) enzymes (272).
As previously described, GST enzymes are important in sulforaphane metabolism by their ability to conjugate the isothiocyanate to glutathione, leading to its excretion (272). The GST isoforms, GST-M1 and GST-T1 have been reported to have the greatest activity on sulforaphane $(151,315)$. 
Table 2. Amount of Glucoraphanin Measured in Important Members of the Family BrassicaCeaE

\begin{tabular}{|c|c|c|c|}
\hline Botanical classification & Range (mean) & Unit & Reference \\
\hline Kohlrabi (Brassica oleracea var. gongylodes & $7.8-8.7$ & $\mathrm{mg} / 100 \mathrm{~g}(\mathrm{fw})$ & $(40)$ \\
\hline Red cabbage (B. oleracea var. capitata f. rubra) & $4.0-18.2$ & $\mathrm{mg} / 100 \mathrm{~g}(\mathrm{fw})$ & $(40)$ \\
\hline Rocket (Eruca sativa) & $\begin{array}{c}2.2-4.4 \\
1.3\end{array}$ & $\begin{array}{l}\mathrm{mg} / \mathrm{g}(\mathrm{dw}) \\
\mu \mathrm{mol} / \mathrm{g}(\mathrm{dw})\end{array}$ & $\begin{array}{l}(144) \\
(144)\end{array}$ \\
\hline Green broccoli (B. oleracea var. italica) & $\begin{array}{c}0.8-21.7(7.1) \\
4.5-28.5 \\
2.4-18.4(15.7) \\
1.3-8.3(4.0) \\
0.3-12.6(4.6) \\
24-185(95) \\
11.6-34.0(22.2) \\
4.1-14.9(10.5) \\
0.37-4.7(2.2)\end{array}$ & $\begin{array}{l}\mu \mathrm{mol} / \mathrm{g}(\mathrm{dw}) \\
\mu \mathrm{mol} / \mathrm{g}(\mathrm{dw}) \\
\mu \mathrm{mol} / \mathrm{g}(\mathrm{dw}) \\
\mu \mathrm{mol} / \mathrm{g}(\mathrm{dw}) \\
\mu \mathrm{mol} / \mathrm{g}(\mathrm{dw}) \\
\mu \mathrm{mol} / 100 \mathrm{~g}(\mathrm{fw}) \\
\mathrm{mg} / 100 \mathrm{~g}(\mathrm{fw}) \\
\mu \mathrm{mol} / \mathrm{g}(\mathrm{dw}) \\
\mu \mathrm{mol} / \mathrm{g}(\mathrm{dw})\end{array}$ & $\begin{array}{l}(157) \\
(236) \\
(25) \\
(283) \\
(13) \\
(74) \\
(243) \\
(32) \\
(2)\end{array}$ \\
\hline Purple broccoli (B. oleracea var. italic) & 6.7 & $\mathrm{mg} / 100 \mathrm{~g}(\mathrm{fw})$ & $(243)$ \\
\hline Purple cauliflower (B. oleracea var. botrytis) & 11.6 & mg/100g (fw) & $(243)$ \\
\hline Chinese broccoli (Brassica rapa var. alboglabra) & $\begin{array}{c}39.7 \\
118.9 \\
0.01\end{array}$ & $\begin{array}{l}\mathrm{mg} / 100 \mathrm{~g} \text { (fw) } \\
\mu \mathrm{mol} / 100 \mathrm{~g} \text { (fw) } \\
\mu \mathrm{mol} / \mathrm{g}(\mathrm{dw})\end{array}$ & $\begin{array}{l}(243) \\
(102) \\
(210)\end{array}$ \\
\hline Green broccoli sprouts (B. oleracea var. italica) & $\begin{array}{l}23.3-67.6 \\
11.1-28.7 \\
17.4-49.5\end{array}$ & $\begin{array}{l}\mu \mathrm{mol} / \mathrm{g}(\mathrm{dw}) \\
\mu \mathrm{mol} / \mathrm{g}(\mathrm{dw}) \\
\mu \mathrm{mol} / \mathrm{g}(\mathrm{dw})\end{array}$ & $\begin{array}{l}(217) \\
(5) \\
(217)\end{array}$ \\
\hline
\end{tabular}

fw, fresh weight; dw, dry weight.

Genetic polymorphisms, as well as geographical and ethnic variations in genotype frequencies have been described for both GST-M1 and GST-T1, including null mutations, which result in the absence of a functional gene product (101). Interestingly, the frequency of a homozygous null genotype for both isoforms is relatively high, with the frequency of the GST-M1 null genotype varying between $39 \%$ and $63 \%$, and the GST-T1 null genotype between $10 \%$ and $21 \%$ for Caucasian populations, but it may be as high as $64 \%$ in subjects of Asian descent (53). The implication of a homozygous null genotype has been shown to be an important variable that determines the biodistribution, and therefore the protective effect of broccoli consumption in human populations. Epidemiological studies, however, have reported conflicting results with regard to the association between genetic polymorphisms in GST isoforms and cancer risk. For example, some studies have concluded that GST-M1-positive subjects gain greater cancer protection from either broccoli consumption or total cruciferous vegetable consumption than those who possess the GST-M1 null genotype (129, 266, 292). In contrast, others report that consumption of cruciferous vegetables leads to a greater protective effect in GSTM1 and GST-T1 null subjects than those with functional GST enzymes $(173,245)$. This variation, however, may be explained through the innate biological function of GST enzymes and their role in the metabolism and subsequent elimination of various compounds after exposure. Specifically, molecular epidemiological studies involved in elucidating the association between GST-M1 and GST-T1 genotypes with cancer susceptibility have shown that those who carry the homozygous deletion appear to have a small increase in the magnitude of risk (odds ratio of $<2$ ); however, other factors (i.e., cigarette smoking) further enhance the risk (odds ratio of 3-5) (228). This is accounted to their ability to regulate the conjugation of carcinogenic compounds, in- cluding benzo(a)pyrene and styrene-7,8-oxide by GST-M1, and ethylene oxide and methyl bromide by GST-T1, to excretable hydrophilic metabolites $(10,59,97,316)$. Through the inability to express functional GST enzymes, individuals possessing the homozygous null genotype have a limited capacity to efficiently detoxify potentially carcinogenic exposures. Thus, the consumption of cruciferous vegetables may have limited protection in such subjects, as chronic exposure to carcinogens causes a reduction in their preventative activity. Conversely, studies that report an enhanced protective effect of sulforaphane in GST-M1 and GST-T1 null genotypes hypothesize that due to the inability to efficiently metabolize sulforaphane for urinary excretion, exposure of target tissues to the protective compound and/or metabolites is higher and prolonged (170).

The sulforaphane metabolites produced in such a pathway are distributed throughout the body and accumulate in different tissues, with unpublished data from Franklin and coworkers after a whole body autoradiographic study in rats suggesting that high concentrations of isothiocyanate metabolites are present in the gastrointestinal tract, liver, kidneys, and blood (26). The basis for the distribution of sulforaphane is the high degree of binding to glutathione, and its capacity to drive passive diffusion $(47,108)$. Due to analytical limitations, a few studies have successfully measured the distribution of sulforaphane and its metabolites in humans. Results from human studies demonstrated that $74 \%( \pm 29 \%)$ of sulforaphane from broccoli extracts may be absorbed in the jejunum, with a portion returning to the intestinal lumen of jejunum as sulforaphane-glutathione (218). The amount of sulforaphane metabolites in plasma, however, may reflect the amount of sulforaphane exposed to tissues, and are, therefore, considered important biomarkers in the determination of distribution (55). In plasma, more than $50 \%$ of total sulforaphane metabolites were sulforaphane-glutathione with free 


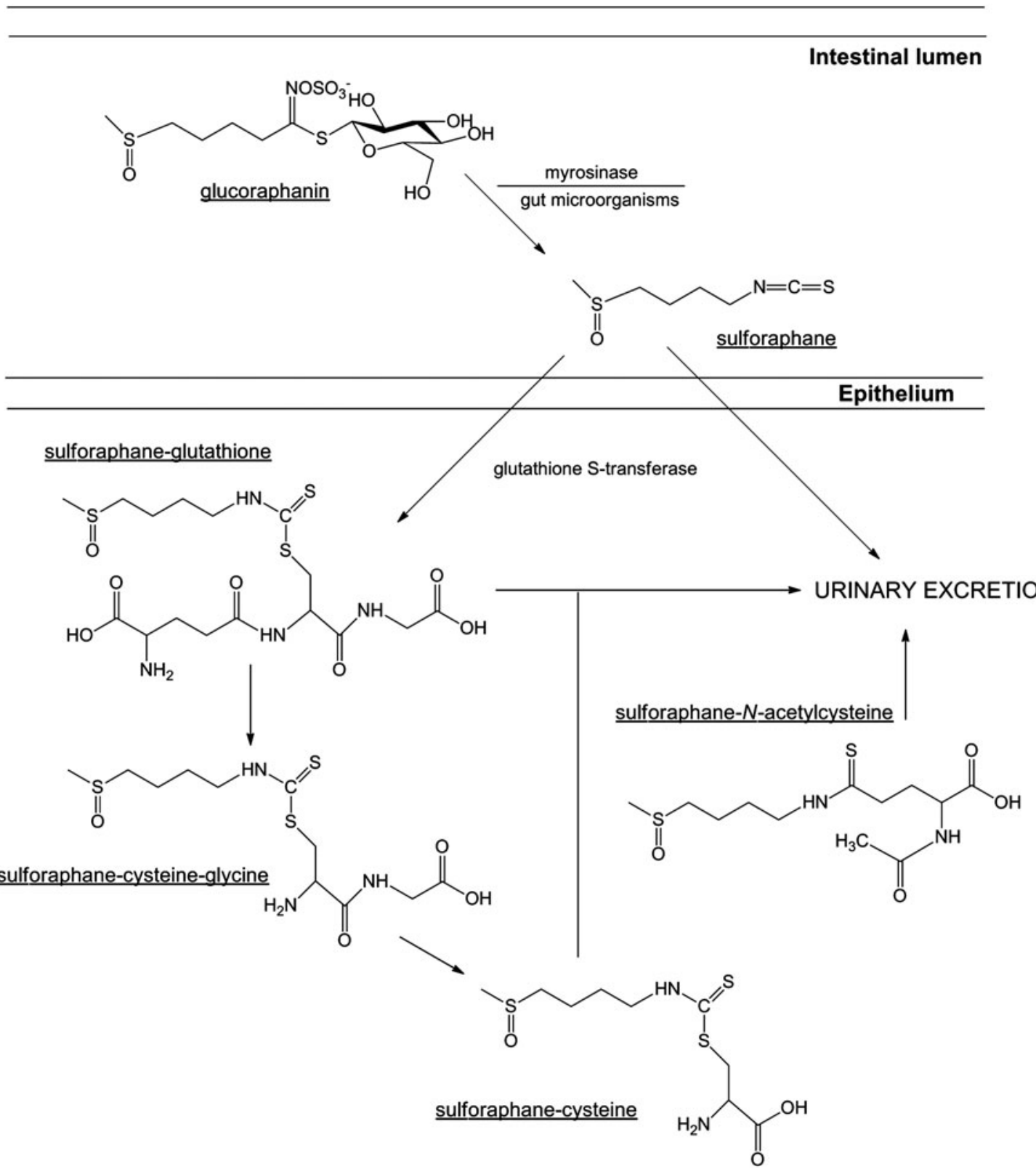

FIG. 3. The conversion of glucoraphanin to sulforaphane, and its subsequent metabolism. Hydrolytic conversion of glucoraphanin to sulforaphane occurs through the action of physical damage to the plant, by either the action of plant-derived myrosinase (intracellular broccoli thioglucosidase) or the microbiota of the human colon. After rapid diffusion into the cells of the intestinal epithelium, sulforaphane undergoes metabolism via the mercapturic acid pathway. This process involves its initial conjugation with glutathione, rapidly catalyzed by important glutathione S-transferase (GST) enzymes. The process of $N$ acetylation (to form sulforaphane- $\mathrm{N}$-acteylcysteine) is important for the subsequent excretion of sulforaphane from the body.

sulforaphane, although other metabolites, including sulforaphane- $N$-acetylcysteine, were present in quantifiable amounts (121). For example, in rats, after a single dose of (50 $\mu \mathrm{mol})$ sulforaphane, detectable levels of the compound were evident after $1 \mathrm{~h}$, peaking at $\sim 20 \mu \mathrm{M}$ at $4 \mathrm{~h}$ with a half life of $\sim 2.2 \mathrm{~h}$ (114). Ye et al. have shown a rapid absorption and appearance of isothiocyanates and their metabolites in the blood of human subjects, with this level observed to decline after first-order kinetics (indicating rapid distribution and/or metabolism (305). These subjects were given a single dose of $200 \mu \mathrm{mol}$ broccoli sprouts isothiocyanate preparation, with isothiocyanate plasma concentrations peaking between 0.943 and $2.27 \mu M 1 \mathrm{~h}$ post exposure, with a half life calculated at $1.77 \mathrm{~h}( \pm 0.13 \mathrm{~h})$. Subsequent accumulation after distribution within target tissue is also an important aspect in the context of sulforaphane and its ability to elicit chemopreventive and anticancer effects. In an in vivo study in mice given 300 or $600 \mathrm{ppm}$ sulforaphane, accumulated sulforaphane and sulforaphane-glutathione plasma concentrations were recorded at $124-254 \mathrm{n} M$ and $579-770 \mathrm{n} M$, respectively (115). Concentrations within the small intestine were also measured, and they were between 3-13 nmol/g of tissue and $14-32 \mathrm{nmol} / \mathrm{g}$ of tissue, respectively (equivalent to $\sim 3-30 \mu M$ of total sulforaphane). Interestingly, the accumulation of sulforaphane 
within the colonic tissue of treated mice corresponded with decreased adenoma formation. Detoxification genes $\mathrm{NQO1}$ and heme oxygenase-1 (HO-1) were also detected in the removed tissue. In addition, the rapid passage of a bolus of preformed sulforaphane in rats did not achieve equal distribution across all tissues, with the highest levels reached in the stomach wall (284). Sulforaphane distribution was decreased in more distal parts of the digestive tract, with the rectum accumulating $\sim 1 \%$ of that found in the stomach. At $24 \mathrm{~h}$ post administration, however, levels were low and approximately equal in all evaluated tissue, indicating the rapidity of sulforaphane metabolism and excretion. A study of human breast tissue after consumption of broccoli sprouts, however, showed that the tissue concentration of isothiocyanates failed to be different from plasma levels (51). The kidney is the major organ involved in the conversion of glutathione conjugates into the corresponding $N$-acetyl-S-cysteine conjugates (176). The process of $\mathrm{N}$-acetylation is important for the subsequent excretion of isothiocyanates from the body. Excretion of sulforaphane and its metabolites have been shown to follow first-order kinetics, with most data indicating clearance from the body within $72 \mathrm{~h}$ of administration $(251,305)$.

Glucoraphanin is relatively stable under chemical and thermal conditions, and, therefore, hydrolysis is mainly enzymatic (myrosinase mediated) (286). Cooking and/or blanching (during freezing process) of cruciferous vegetables inactivates myrosinase, and has been shown to decrease the bioavailability of sulforaphane $(47,239,287)$. In general, results suggest that only about $30 \%-50 \%$ of the initial administered dose is excreted after these preparation processes $(127,240)$. Boiling for more than $1 \mathrm{~min}$, or steaming for more than 4-5 min has been shown to lead to the loss of myrosinase activity (291). Conaway et al. performed a study to assess the metabolic fate of glucosinolates after ingestion of steamed and fresh broccoli in 12 male subjects in a crossover design (47). Results of this study indicate that the bioavailability of sulforaphane from fresh broccoli is approximately thrice higher than that from cooked broccoli. Interestingly, coadministration of semi-purified glucoraphanin with a myrosinase source was reported to increase the bioavailability of the isothiocyanate (54). In addition, the concentration of glucoraphanin varies widely among development stages of the plant, and between different parts of the plant, which may also influence sulforaphane bioavailability $(45,210,226)$. For example, two varieties of broccoli, a purple-sprouting broccoli and a green-sprouting broccoli, were cultivated to compare the amount of sulforaphane and its metabolites within commercial samples (234). In the initial samples, it was shown that there were quantitative differences between organs, with the seeds, edible sprouts, and florets determined to possess the most intact sulforaphane (in descending order). Furthermore, these two varieties produced higher sulforaphane levels compared with those within the commercial samples. Higher sulforaphane concentrations were also found in the initial steps of the digestion process, with the concentration of sulforaphane and its subsequent metabolites decreased in accordance with the amount of precursor glucoraphanin.

The concentration of sulforaphane required to observe therapeutic activity has not yet been determined in human clinical trials, with rough estimates based on the active dose in animal models (108). The amount of dietary glucoraphanin that is converted to bioavailable sulforaphane is typically calculated as $20 \%$ of the overall consumed amount in humans (250-252). For example, the typical sulforaphane concentration that has been shown to inhibit the growth of human cancer xenografts in mice is $\sim 4.4 \mathrm{mg} / \mathrm{kg}$ per day (133). This corresponds to $308 \mathrm{mg}$ of sulforaphane daily administered to a $70 \mathrm{~kg}$ person (108).

\section{Chemopreventive Activity Against the Initiation of Carcinogenesis}

Chemoprevention, which refers to the use of a nontoxic natural or synthetic chemical that possesses the capacity to intervene in multistage carcinogenesis, has emerged as a promising approach to reduce the risk of the development and progression of malignancy (163). Microarray analyses in cell lines, animal tissue, and human biopsy samples have shown the capacity of sulforaphane to modulate global gene expression, especially resulting in the differential expression of genes that are important in chemoprevention (Table 3). In general, results indicate that sulforaphane affects the expression of genes involved in xenobiotic metabolism, antioxidation, cell cycle regulation, apoptotic pathways, and stress response $(115,179,306)$.

Evidence suggests that sulforaphane, its metabolites, and synthetic analogues possess the capacity to inhibit the malignant transformation of various cell types, and limit cancer progression after carcinogen exposure (71, 92). For example, sulforaphane and its conjugate metabolite $N$-acetylcysteine was shown to limit the malignant progression of lung adenomas in A/J mice exposed to tobacco carcinogens (49). Prevention of mutagenesis by sulforaphane was also demonstrated in mice given a single application of the sulfur mustard analogue, 2-(chloroethyl) ethyl sulphide (CEES) (1). Abel et al. reported that a single topical treatment with sulforaphane induced the production of phase II detoxification enzymes, with an increase in the epidermal levels of the regulatory subunit of glutamate-cysteine ligase, and reduced glutathione. Furthermore, sulforaphane treatment limited the CEES-induced increase in mutation frequency in the skin, which was measured at 4 days post exposure. A reduction in the number, size, and development of mammary tumors in rats after exposure to the carcinogen dimethylbenz[a]anthracene has also been observed with sulforaphane treatment $(73,312)$. Furthermore, sulforaphane possessed an ability to decrease the amount of DNA-adduct formation in normal mammary cells exposed to polycyclic aromatic hydrocarbons (259). Inhibition of DNA-adduct formation has also been displayed in human bladder cells in vitro and in mouse bladder tissue in vivo, after treatment with sulforaphane and exposure to the bladder carcinogen, 4-aminobiphenyl (60). This inhibition was dependent on the activation of an important chemoprotective signaling pathway, nuclear factor erythroid 2-related factor 2 (Nrf2), within the epithelium, which is the main site for bladder cancer development. Exposure to benzo[a]pyrene results in the induction of pulmonary carcinogenesis in mice via oxidative damage, with sulforaphane treatment found to decrease the production of $\mathrm{H}_{2} \mathrm{O}_{2}$ (134). Results suggest that sulforaphane leads to the activation of apoptotic pathways in this experimental model of chemical lung carcinogenesis, included the increased release of cytochrome c from mitochondria, enhanced caspase-3 activity leading to DNA fragmentation, and 


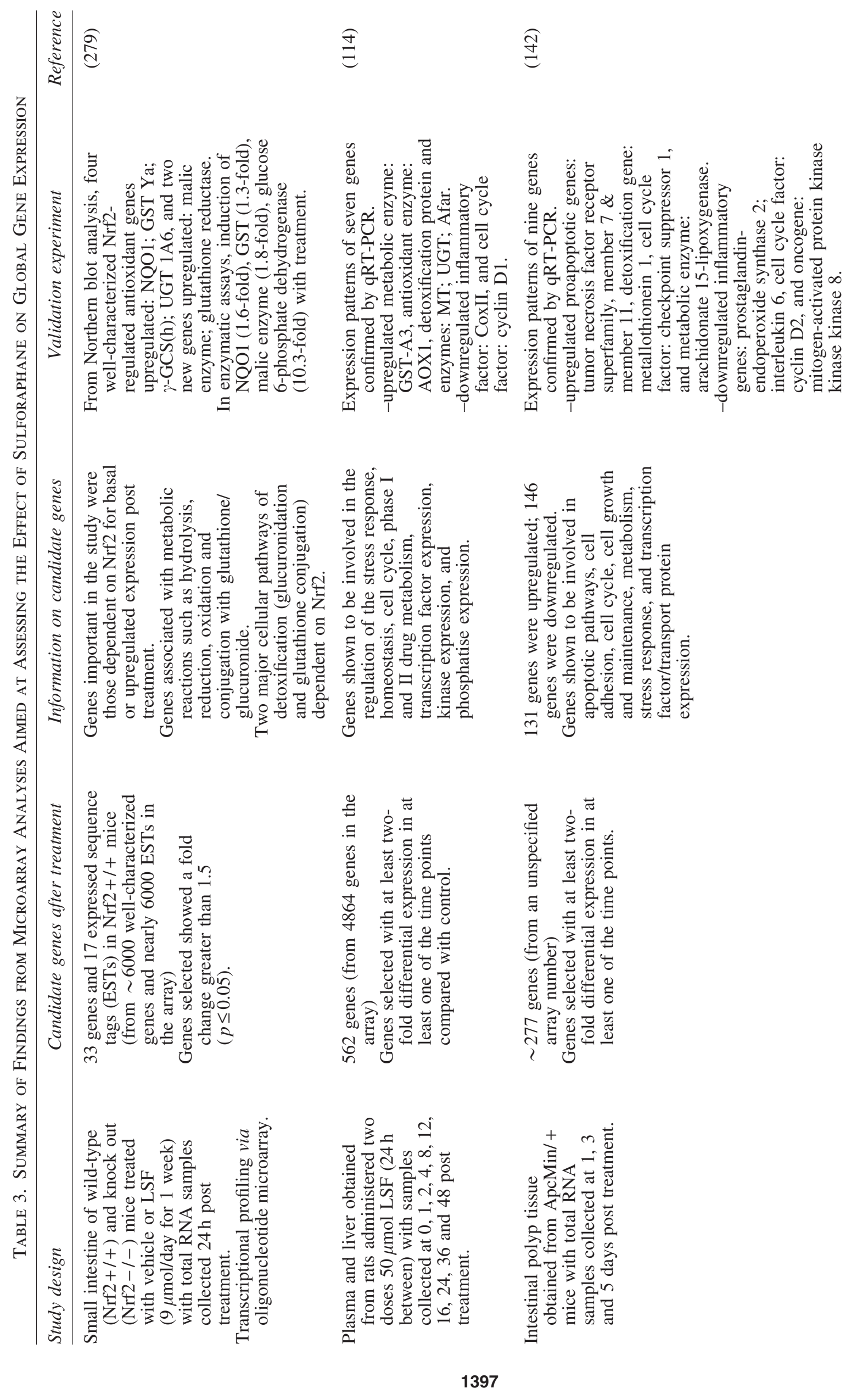




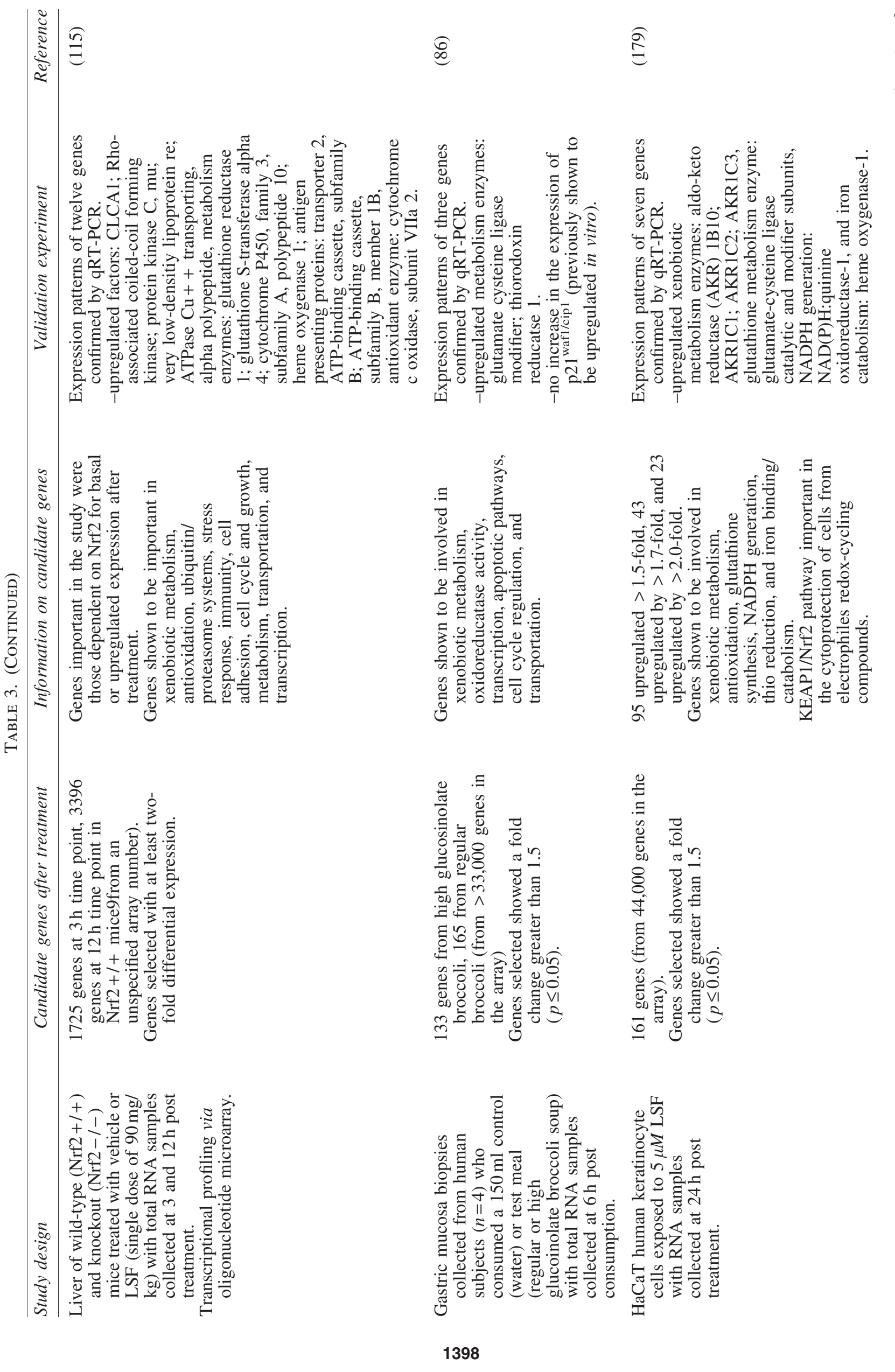




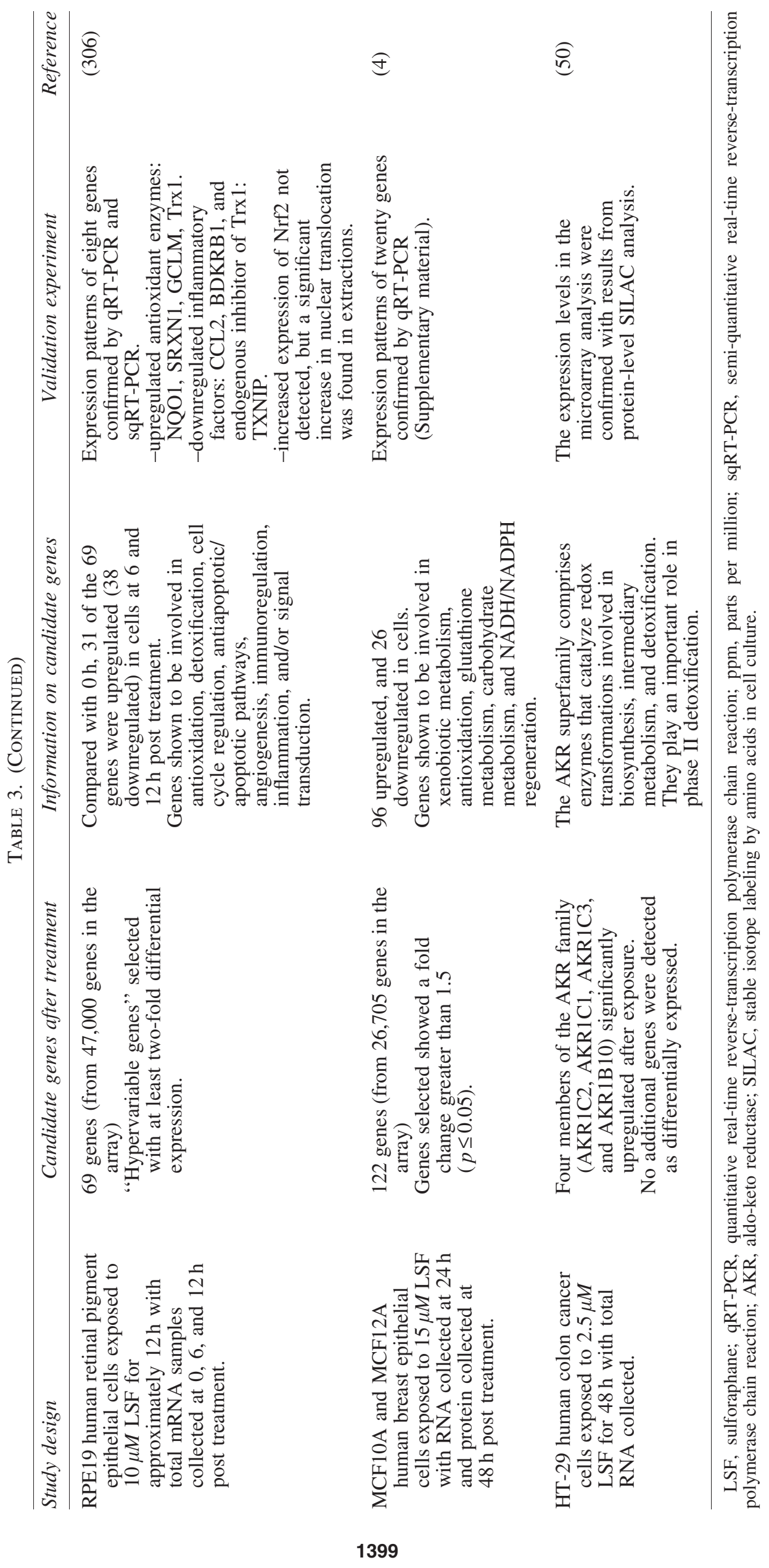


a decrease in Bcl-2 expression coupled with an increase in the expression of Bax. Interestingly, sulforaphane was shown to protect primary dermal fibroblasts and keratinocytes against oxidative stress caused by UVA radiation under basal conditions and in the presence of the photosensitising drug, 6thioguanine (20). In this study, sulforaphane treatment resulted in an $\sim 50 \%$ reduction in the formation of reactive oxygen species (ROS). Furthermore, the protective properties of sulforaphane were shown to be caused by an increase in Nrf2-depednent cytoprotective responses, including those involved in the induction of gene transcription and expression of important metabolic and detoxification enzymes.

The chemopreventive activity of sulforaphane in carcinogenesis is related to the inhibition of phase I enzymes, which are responsible for the activation of pro-carcinogens (15, 313 ) and the induction of phase II enzymes that are responsible for mutagen elimination (314). Phase I enzymes such as cytochrome p450 (CYP) are important in the transformation and bioactivation of pro-carcinogens to carcinogens (297). Through common enzymatic processes, electrophilic intermediates covalently bind to nucleophilic sites in important macromolecules (77). Adduct formation, coupled with inadequate reparation, may, in turn, cause miscoding and mutations in critical genes to initiate carcinogenesis. Multiple studies have reported the capacity of sulforaphane to inhibit the catalytic activity of phase I enzymes $(15,181)$. Specifically, Barcelo et al. reported the dose-dependent inhibition of both cytochrome p450-1A1 and -2B1/2 enzymatic activity in rat hepatocytes after sulforaphane treatment (15). Similar results were also found in human hepatocytes, with sulforaphane significantly decreasing the expression of CYP1A1, 1A2, and CYP3A4 genes (96). Evidence also suggests that sulforaphane is an effective antagonist of the human steroid and xenobiotic receptor (SXR), which is an important transcriptional factor that regulates the expression of CYP3A genes (318). In primary rat hepatocytes, sulforaphane caused a significant inhibition of the microsomal ethoxyresorufin-Odeethylase (EROD) activity (a selective marker for CYP1A1 and 1A2) and P-benzoquinone dioxime (BQD) activity (a marker of CYP3As) (158).

Cells possess innate protective mechanisms in order to minimize damage caused by highly reactive metabolites, with the induction of phase II enzymes that are of major importance in detoxification. These enzymes include GST, $\mathrm{NAD}(\mathrm{P}) \mathrm{H}$ :quinine oxidoreductase (NQO-1), and UDPglucuronosyltransferase (UGT) (138). Phase II enzymes are potent antioxidants that have a relatively long half life, and have the capacity to conjugate endogenous substrates such as glutathione to phase I metabolites in order to limit further biotransformation and result in enhanced elimination and excretion (35). Evidence suggests that sulforaphane is a potent inducer of phase II antioxidant enzymes (61). For example, sulforaphane significantly reduced the number and level of DNA adducts after exposure to methyl-6-phenylimidazo[4,5-b]pyridine in a dose-dependent manner in hepatocytes due to the induction of GST-A1 and UGT-1A1 mRNA expression (11). NQO-1 and GST activity was also shown to be enhanced in the forestomach, duodenum, and bladder of rats treated with $40 \mu \mathrm{mol}$ of sulforaphane per $\mathrm{kg}$ (197), while an increased dose of $200-1000 \mu \mathrm{mol}$ of sulforaphane per $\mathrm{kg}$ increased activity in the liver, colon, and pancreas (183). Jones and Brooks demonstrated an increase in enzymatic activity in prostate, liver, kidney, and bladder tissues after administration of sulforaphane (128). Human clinical studies also provide evidence for the induction of phase II enzymes by sulforaphane after broccoli consumption (Table 4).

The induction of phase II enzymes by sulforaphane has been shown to be associated with a disruption of Nrf2-Keap1 interactions and increased translocation of Nrf2 (Fig. 4) (117,

Table 4. Human Clinical Studies Involving the Consumption of Broccoli and Sulforaphane-Induced Production of Phase II Enzymes

\begin{tabular}{|c|c|c|}
\hline Study design & Conclusions & Reference \\
\hline $\begin{array}{l}\text { Two-week, randomized, placebo-controlled study: } \\
100 \mu \text { mol glucoraphanin infusion with } 200 \text { healthy } \\
\text { Chinese adults }\end{array}$ & $\begin{array}{l}\text { Sulforaphane is absorbed and induces the } \\
\text { production of phase II detoxification } \\
\text { enzymes. }\end{array}$ & (139) \\
\hline $\begin{array}{l}\text { Four-week, randomized, crossover study: }>160 \mathrm{~g} / \mathrm{day} \\
\text { of CV vs. Micronutrient }+ \text { fiber with } 20 \text { healthy } \\
\text { adults (36-80 years) }\end{array}$ & $\begin{array}{l}\text { Intake of CV is associated with lower levels } \\
\text { of oxidative stress indicators. }\end{array}$ & (81) \\
\hline $\begin{array}{l}\text { Single-dose perfusion of proximal jejunum: } 2 \mathrm{ml} / \mathrm{min} \\
\text { broccoli extract with } 11 \text { subjects }\end{array}$ & $\begin{array}{l}\text { Sulforaphane is efficiently absorbed in the } \\
\text { small intestine (74\%) and rapidly induces } \\
\text { phase II (GSTA3) mRNA. }\end{array}$ & (218) \\
\hline $\begin{array}{l}\text { Single-dose, randomized, three-phase crossover study } \\
\text { with standard broccoli and broccoli containing } \\
\text { threefold amounts of glucoraphanin with } 16 \\
\text { subjects (18-46 years) }\end{array}$ & $\begin{array}{l}\text { Sulforaphane is bioavailable and is } \\
\text { correlated with dose. } \\
\text { Rapidly induces phase II (TrxR) mRNA. }\end{array}$ & (86) \\
\hline $\begin{array}{l}\text { Placebo-controlled, dose-escalation trial }(25-100 \mathrm{~g} \\
\text { broccoli sprout homogenate) with } 65 \text { healthy } \\
\text { subjects ( }>18 \text { years) }\end{array}$ & $\begin{array}{l}\text { Broccoli sulforaphane rapidly induces phase } \\
\text { II (NQO1, GST-M1, GST-P1, and HO-1) } \\
\text { mRNA in upper airways of humans. }\end{array}$ & $(231)$ \\
\hline $\begin{array}{l}\text { Four-week, placebo-controlled, randomized, double- } \\
\text { blind, two-dose trial: } 5 \text { and } 10 \mathrm{~g} / \text { day broccoli sprout } \\
\text { powder with } 63 \text { type II diabetic patients }\end{array}$ & $\begin{array}{l}\text { Biomarkers of oxidative stress were reduced } \\
\text { at both doses. } \\
\text { Oxidized low-density lipoprotein reduced by } \\
5 \% \text { with the } 10 \mathrm{~g} / \text { day treatment. }\end{array}$ & (12) \\
\hline
\end{tabular}

$\mathrm{CV}$, cruciferous vegetables; mRNA, messenger RNA. 
FIG. 4. Sulforaphane-modulated Nrf2-Keap1 interactions in the transcription of phase II antioxidant enzymes. Sulforaphane has the ability to induce nuclear translocation of Nrf2 through the disruption of the Nrf2-Keap1 complex via the degradative loss of Keap1 via conformational changes. Specific modifications of Keap1 release Nrf2 from sequestration, promoting its nuclear translocation and activation. Activation of Nrf2 in the nucleus occurs through its heterodimerization with small Maf transcription factors to form a complex that binds to the antioxidant/electrophile response element (ARE/EpRE) that is found in the promoters of many phase II enzymes, ultimately leading to ARE-driven gene expression (and subsequent upregulation of phase II antioxidant enzymes).

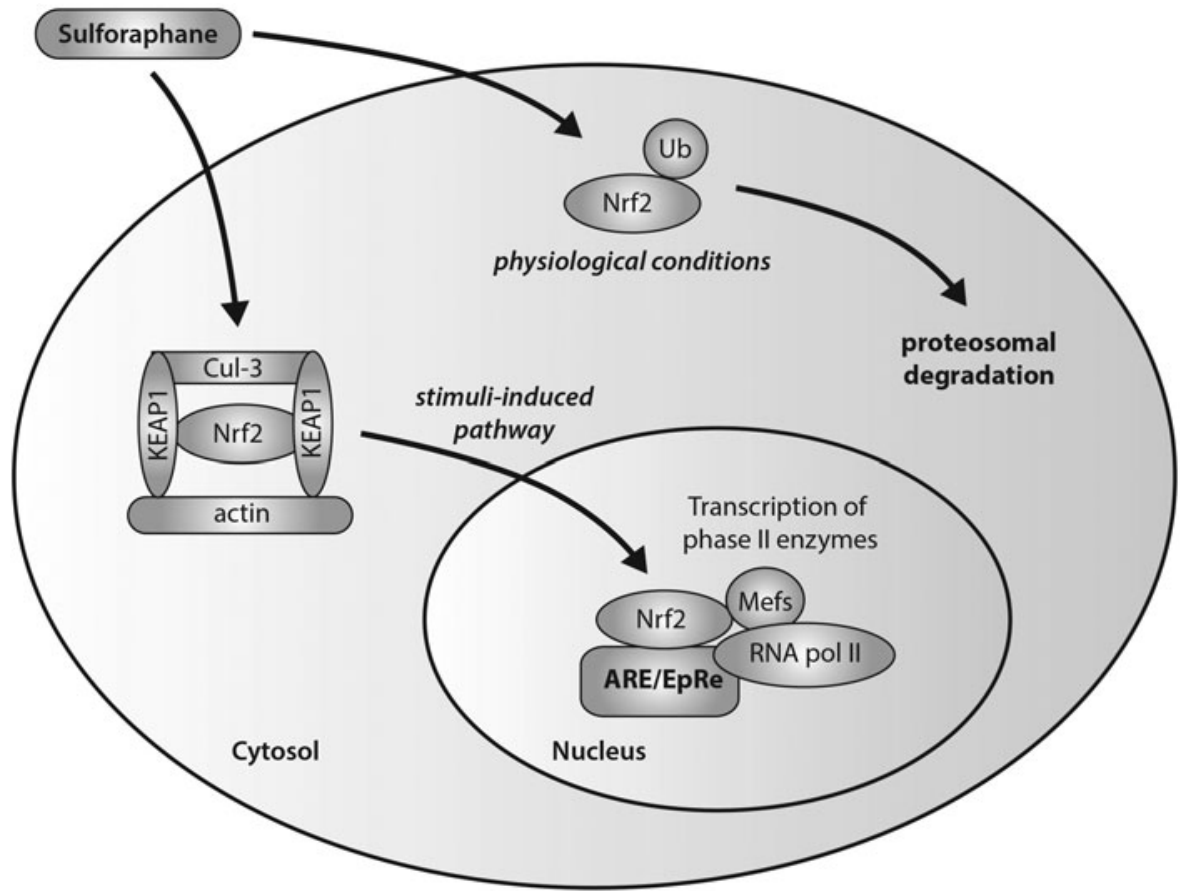

148, 206). In unstimulated cells, Kelch-like ECH-associated protein 1 (Keap1) mediates the function of Nrf2 through sequestration mechanisms in order to bind it to Cul-3dependent ubiquitinase for subsequent ubiquitination and targeted proteosomal degradation. After stimulation due to environmental insult, the Nrf2-Keap1 complex is disrupted with conformational changes, leading to a switch in ubiquitination from Nrf2 to Keap1, and the nuclear translocation of Nrf2. Activation of Nrf2 in the nucleus occurs through its heterodimerization with small Maf transcription factors to form a complex that binds to the antioxidant/electrophile response element (ARE/EpRE) that is found in the promoters of many phase II enzymes. Sulforaphane has the ability to induce nuclear translocation of Nrf2 through the disruption of the Nrf2-Keap1 complex via the degradative loss of Keap1 via conformational changes (62). Specifically, sulforaphane has been demonstrated, with the use of spectroscopic evidence, to react with the thiol groups of Keap1 to form thionoacyl adducts $(62,110)$. This specific modification of Keap1 released Nrf2 from sequestration, promoting the subsequent activation of ARE-driven gene expression. Conceptual proof of this action by sulforaphane has been shown through experiments in Nrf2 knockout mice (279). Thimmulappa et al. generated a transcriptional profile of the small intestine of wild-type $(\mathrm{Nrf} 2+/+)$ and knockout $(\mathrm{Nrf} 2-/-)$ mice treated with sulforaphane. Numerous genes were found to be regulated by Nrf2, including the previously reported phase II xenobiotic metabolizing enzymes, as well as antioxidative and cytoprotective proteins that are important in limiting cancer progression.

\section{Anticancer Properties of Sulforaphane Limiting Tumor Progression}

In addition, evidence suggests that sulforaphane possesses the capacity to limit the progression of tumor development through a number of mechanisms, including activation of apoptosis, NF $\kappa$ B pathway inhibition, and cell cycle arrest induction (Fig. 5).

Apoptosis or programmed cell death is an important and selective mechanism in the regulation of cell proliferation in both physiological and pathological conditions (229). The activation of apoptotic pathways in malignant cells is a major focus for current cancer therapeutic research, with evidence suggesting that sulforaphane possesses the capacity to induce apoptosis through the activation of several proapoptotic pathways (238). For example, sulforaphane induced apoptotsis in both human cervical HeLa cancer and hepatocellular HepG2 carcinoma cell lines in vitro, demonstrated by the formation of apoptotic bodies and the accumulation of cells in the sub-G1 phase (215). Administration of $10 \mu \mathrm{M}$ sulforaphane reduced cell viability and induced apoptosis in prostate DU145 cancer cells as indicated by the cleavage of poly(ADP-ribose) polymerase (PARP) and increased release of histone-associated DNA fragments (38). In HCT-116 colon cancer cells, $15 \mu \mathrm{M}$ sulforaphane induced activation of proapoptotic caspase-7 and caspase-9, independent of p53 expression (212). Recently, sulforaphane-induced apoptotis was also associated with the activation of caspase- 8 and caspase-9, the initiating caspases that are important in both extrinsic and intrinsic apoptotic pathways in human bladder 5637 cancer cells (214). Park et al. also reported the ability of sulforaphane to affect important molecular targets that are intimately involved in apoptotic pathways, including the downregulation of anti-apoptotic Bcl-2 and Bcl-XL gene expression, the upregulated expression of pro-apoptotic Bax, proteolytic activation of caspase-3, and the degradation/cleavage of PARP (215). The activation of Bax, the downregulation of the inhibitors of apoptosis (IAP) protein family, and the induction of apoptotic protease activating factor- 1 have been shown to be involved in the regulation of sulforaphane-induced cell death (39). A study using Jurkat T-leukemia cells suggests that vulnerability to 


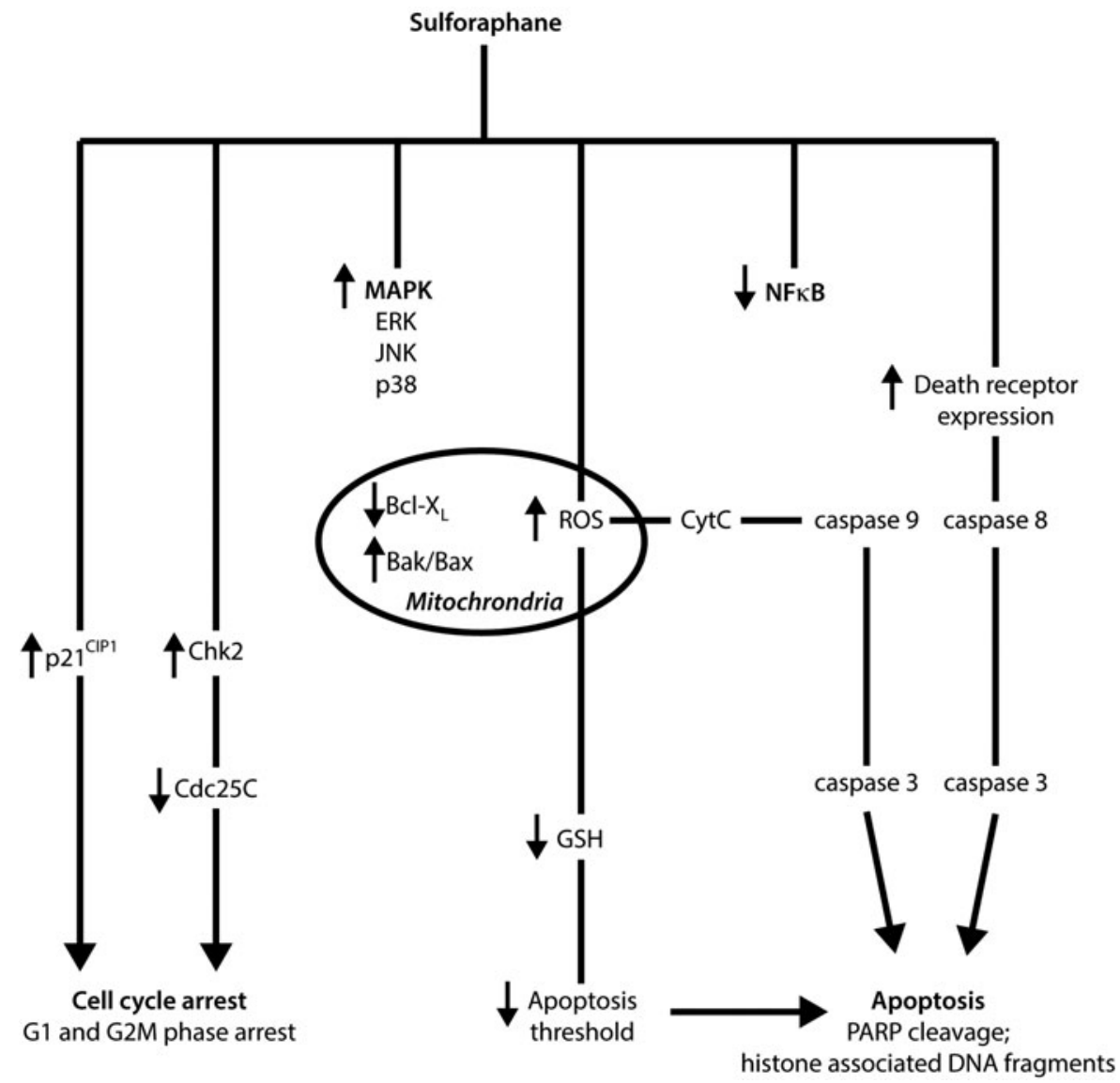

FIG. 5. Summary of chemopreventive mechanisms involved in limiting tumor progression after sulforaphane exposure. Both in vitro and in vivo studies have demonstrated that sulforaphane possesses the capacity to activate apoptotic pathways, induce cell cycle arrest, inhibit NF $\kappa$ B signaling, and stimulate MAPK activity. sulforaphane-mediated apoptosis was dependent on cell-cycle mechanisms, with cells most sensitive to sulforaphane-induced apoptosis in the G1 phase, less sensitive in the G2/M phase, and least sensitive during the $\mathrm{S}$ phase (78).

The proposed initiating signal of sulforaphane-mediated apoptosis is the formation of ROS and the disruption of mitochondrial membrane potential, leading to cytosolic release of cytochrome c via both death-receptor and mitochondrial caspase cascade pathways, as observed in human prostate cancer PC3 cells (258). More specifically, sulforaphane was capable of inducing apoptosis through the activation of the ROS-dependent, caspase-3 in multiple tumor necrosis factor- $\alpha$-resistant leukemia cell lines (194). Interestingly, administration of the antioxidant $\mathrm{N}$-acetylcysteine and the overexpression of catalase resulted in the reversal of sulforaphane-induced ROS formation in the same study. Singh and co-workers thus indicated a necessity for the conjugation of sulforaphane with glutathione during metabolism, in order to deplete intracellular concentrations of glutathione and potentially lower the oxidative stress threshold of cells. In general, high concentrations of sulforaphane are required in order to induce ROS formation. For example, mitochondrial ROS generation and disruption of mitochondrial membrane potential leading to the formation of acidic vesicular organelles and autophagy in PC3 and LNCap cells may only be observed after administration of $40 \mu M$ sulforaphane (105). This response has unique morphological effects and was shown to possess the ability to inhibit the release of mitochondrial cytochrome $\mathrm{c}$ and apoptosis. Therefore, it has been suggested that ROS production after sulforaphane treatment has the capacity to influence cell death in an alternative pathway to apoptosis.

While activation of apoptosis by sulforaphane in the human breast cancer MDA-MB-231 cells was reported to be initiated through the induction of Fas ligand, which resulted in the activation of caspase-8, caspase-3, and PARP, sulforaphane induced apoptosis in the human breast cancer cell lines, MDA-MB-468, MCF-7, and T47 via mechanisms involved with decreased Bcl-2 expression, release of cytochrome $\mathrm{c}$ into the cytosol, activation of caspase-9 and caspase-3 (but not caspase-8), and poly(ADP-ribose) polyermase cleavage (219). Taken together, these findings indicate that sulforaphane has an innate ability to modulate both extrinsic and intrinsic apoptotic pathways, via the production of ROS and regulation of gene expression.

In contrast to the well-documented induction of apoptotic pathways by sulforaphane, recent studies have indicated that sulforaphane may also possess the capacity to cause autophagy in cancer cells. The significance of these findings is displayed in the publication by Herman-Antosiewicz et al., which associated the induction of autophagy with the inhibition of cytochrome c release and, ultimately, apoptosis (106). In this study, treatment of prostate cancer cell lines, PC-3 and LNCap with sulforaphane resulted in the upregulation, processing, and recruitment to autophagosomes of microtubule-associated protein light chain 3 (LC3). In addition, inhibition of autophagy (incubation of cells with 3-methyladenine) potentiated the proapoptotic effects of 
sulforaphane in human colon cancer cells (207). Similar results were also demonstrated in human breast cancer cell lines, MCF-7 and MDA-MB-231 (136). Investigation providing mechanistic insights indicates that autophagy and cell death signaling after sulforaphane treatment of pancreatic cells are independent pathways which depend on ROS production (204). Pharmacologic inhibition of autophagy in vivo validated cell culture studies, with most suggesting that autophagy is a cytoprotective mechanism against sulforaphaneinduced apoptosis (290).

Inhibition of cellular growth may also be caused by an irreversible arrest during the cell cycle, with sulforaphane shown to possess such inhibitory effects on cells $(84,257)$. A significant increase in $\mathrm{G} 2 / \mathrm{M}$ cell cycle arrest was observed in LNCap prostate cancer cells after sulforaphane incubation in a concentration- and time-dependent manner (107). A reduction in cell viability after the induction of G2/M cell cycle arrest after treatment of DU145 prostate cancer cells with $10 \mu M$ sulforaphane has also been demonstrated (38). In human ovarian PA-1 cancer cells treated with sulforaphane, an accumulation in the G2/M (metaphase) phase was reported through the downregulation of CDC2, as well as through the downregulation and dissociation of the cyclinB1/CDC2 complex (31). A decrease in protein levels of cyclin B1, cell division cycle Cdc25B, Cdc25C, and an accumulation of Tyr15-phosphorylated (inactive) Cdk1 has also shown to be important in sulforaphane-mediated cell cycle arrest in PC3 cells after incubation with $20 \mu M$ sulforaphane (257). In addition, sulforaphane treatment resulted in a rapid and sustained phosphorylation of Cdc25C at Ser-216, which was a result of Chk2 activation, leading to translocation of $\mathrm{Cdc} 25 \mathrm{C}$ from the nucleus to the cytoplasm, and increased binding to 14-3-3beta. It is thus proposed that Chk2-mediated phosphorylation of $\mathrm{Cdc} 25 \mathrm{C}$ is an important regulation mechanism in irreversible sulforaphane-induced G2/M arrest.

The tumor suppressor and cell cycle inhibitor protein p21 also appears to play an important role in sulforaphaneinduced cell cycle arrest with its induction observed in a number of studies irrespective of cell type and expression of p53. Sulforaphane treatment of p53 negative colon cancer cell lines (HT-29 and Caco-2) was shown to induce p21 expression (216). In LNCap prostate cancer cells, induction of p53 and p21 was observed after $20 \mu M$ sulforaphane treatment (199). Interestingly, cell cycle arrest in LNCap cells occurred after the p21 expression induction but not p53. In this same study, induction of p21 expression by sulforaphane was shown to occur in p53-null PC3 prostate cancer cells, suggesting a possible p53-independent regulatory pathway. Treatment of acute lymphoblastic leukemia cells from human patients with sulforaphane resulted in dose-dependent apoptosis and G2/M cell cycle arrest (274). These anticancer mechanisms were associated with the activation of caspases $(3,8$, and 9), inactivation of PARP, p53-independent upregulation of $\mathrm{p} 21$, and inhibition of the CDC2/cyclin B1 complex. Colon tissue surgically removed from three human subjects treated with sulforaphane for $2 \mathrm{~h}$ exhibited a strong induction of p21 in cancer tissue, with expression failing to be significant in the normal tissue of two patients (282).

Although G2/M arrest is the predominant stage of cell cycle arrest induced by sulforaphane $(84,216)$, arrest at other phases of the cell cycle has been observed. For example, a G1 cell cycle arrest was shown to occur in HT-29 cells concomitant with an increase in $\mathrm{p} 21^{\mathrm{CIP} 1}$, and a decrease in cyclin D1, cyclin A, and c-myc (254). G1/S cell cycle arrest has also been reported in LNCap and DU145 cells $(37,293)$. Evidence suggests that the phase in which cell cycle arrest occurs after sulforaphane treatment is dependent on administered concentration and incubation time. In human colon adenocarcinoma Caco-2 cells, G2/M cell cycle arrest was observed at a dose of $20 \mu M$ sulforaphane (120). Conversely, administration of sulforaphane at concentrations $>20 \mu M$ induced an accumulation of sub-G1 cells and the loss of mitochondrial membrane potential. Pappa et al. demonstrated reversible G2/M cycle arrest and cytostatic growth of p53 wild-type 40-16 colon cancer cells after transient exposure till $6 \mathrm{~h}$ (211). Treatment with sulforaphane for longer than $12 \mathrm{~h}$, however, resulted in irreversible G2/M arrest and subsequent apoptosis. Interestingly, cytostatic growth effects observed with $12 \mathrm{~h}$ of exposure was sustained till $72 \mathrm{~h}$ post sulforaphane removal and the $\mathrm{IC}_{50}$ calculated was comparable to cells transiently exposed to sulforaphane for $72 \mathrm{~h}$.

Mitogen-activated protein kinases (MAPKs), including the extracellular signal-regulated kinases (ERKs), c-Jun $\mathrm{NH}_{2}$-terminal kinases ( $\mathrm{JNK}$ ), and $\mathrm{p} 38$, are believed to be involved in carcinogenesis and tumor progression (41). The activation of the MAPK/ERK pathway has been reported after sulforaphane treatment in a number of cell lines, including PC3 cells, through the activation of the activator protein-1 (AP-1) transcription factor that is involved in the regulation of cell death (303). The modulatory effect on AP-1 transcription is dependent on the concentration of sulforaphane administered. In HT-29 colon cancer cells, activation of AP-1 luciferase activity occurred at low concentrations of sulforaphane treatment $(\leq 35 \mu M)$, while activity was inhibited at high concentrations $(\geq 50 \mu M)$ (124). In addition, cyclin D1 levels increased at lower concentrations, and decreased at high concentrations. Interestingly, however, is that despite the difference in modulation after varying concentrations of sulforaphane, cell viability decreased in a dosedependent manner. Administration of $50 \mu M$ sulforaphane in cells corresponded to activation of the $46-\mathrm{kDa}$ isoform of phospho-JNK (p46-JNK) but not the p54-JNK isoform, indicating the importance of the $54-\mathrm{kDa}$ isoform for persistent activation of AP-1. Consistent with this report, Shen et al. also observed a decrease in cell viability and the activation of MAPK pathways (including, ERK, JNK, and p38) (254). Furthermore, activated JNK was shown to decrease cyclin D1 expression at high concentrations of administered sulforaphane. The treatment of Caco-2 human colon adenocarcinoma cells with sulforaphane was shown to induce ERK activation, but failed to significantly increase the activation of JNK and p38 (120). In another study, DU-145 prostate cancer cells were exposed to sulforaphane with the activation of the JNK pathway shown to be important in cell death induction (38). Activation of p38 was also shown to be important in the upregulation of Nrf2-ARE-driven enzymes, and the downregulation of pro-inflammatory COX-2 in human bladder T24 cancer cells (247). The MAPK pathway is, therefore, an important mechanism activated by sulforaphane, and indirectly contributes to cell death and cell viability regulation, as well as to Nrf2-Keap1 interactions and the transcription of phase II antioxidant enzymes.

Nuclear factor $\mathrm{B}(\mathrm{NF} \kappa \mathrm{B})$ and its active role in inflammation, cancer cell survival, and progression has been widely 
reported, with the ability to bind to the promoter of many proinflammatory genes, including inducible nitric oxide synthase (iNOS), cyclooxygenase-2 (COX-2), and tumor necrosis factor (TNF) (137). After incubation of PC3 cells with $20 \mu M$ sulforaphane for $1 \mathrm{~h}$, a reduction in nuclear localization of $\mathrm{p} 65-\mathrm{NF} \kappa \mathrm{B}$ was observed (39). In addition, inhibition of $\mathrm{NF} \kappa \mathrm{B}$ transcriptional activity in $\mathrm{PC} 3$ cells resulted in the suppression of the nuclear translocation of p65 and the decreased gene expression of $\mathrm{NF} \kappa \mathrm{B}$-regulated VEGF, cyclin D1, and Bcl- $\mathrm{x}_{\mathrm{L}}$ (302). The decreased nuclear translocation and activation of p65-NF $\kappa \mathrm{B}$ was attributed to the inhibition of $\mathrm{I} \kappa \mathrm{B}$ kinase (IKK) phosphorylation, which is necessary for $\mathrm{I} \kappa \mathrm{B}$ degradation, and subsequent release of inactive $\mathrm{NF} \kappa \mathrm{B}$ to become active. Similar effects are observed in HT-29 cells in a dosedependent manner (125). Interestingly, an initial increase in $\mathrm{NF} \kappa \mathrm{B}$ activity at $6-12 \mathrm{~h}$ post sulforaphane treatment in LNCap cells has also been observed, followed by inhibition at the $24 \mathrm{~h}$ time point (39). In this same study, the modulation of the IAP family, downstream factors that are shown to be upregulated by $\mathrm{NF} \kappa \mathrm{B}$ activation, was directly proportional to the level of $\mathrm{NF} \kappa \mathrm{B}$ activity. Studies also suggest that sulforaphane has the capacity to reduce the DNA binding ability of $\mathrm{NF} \kappa \mathrm{B}$ directly, with two mechanisms proposed (36). The first involves the modification of $\mathrm{NF} \kappa \mathrm{B}$ subunits via thioldependent interactions to cause dithiocarbamate formation and the direct binding to essential cysteine (Cys) residues of $\mathrm{NF} \kappa \mathrm{B}$, thereby decreasing the capacity to bind to nuclear DNA (104). The other suggests that sulforaphane may interact with glutathione and other redox regulators such as thioredoxin or redox factor-1 (Ref-1), which, in turn, indirectly interferes with NF $\kappa$ B-DNA binding. Sulforaphane has been identified as an inhibitor of the thioredoxin/thioredoxin reductase (TrxR) enzymatic activity in vitro (103). Findings also suggest that the inhibition of 12-O-Tetradecanoylphorbol-13acetate (TPA)-induced matrix metalloproteinase-9 (MMP-9) expression and cell invasion by sulforaphane is mediated by the suppression of the NF $\kappa$ B pathway in human breast MCF-7 cancer cells (162). Furthermore, the selective inhibition of $\mathrm{NF} \kappa \mathrm{B}$ by sulforaphane has been demonstrated in receptor activator of nuclear factor kappa-B ligand (RANKL)induced osteoclastogenesis through the interaction with the thiol groups of $\mathrm{NF} \kappa \mathrm{B}$ (145). Coactivators of $\mathrm{NF} \kappa \mathrm{B}$ may also be affected by sulforaphane, including CCAAT-enhancerbinding proteins, cAMP response element-binding protein, and AP-1 (299). Woo and Kwon demonstrated the capacity of sulforaphane to inhibit such coactivators, and, ultimately, its indirect ability to downregulate the expression of proinflammatory COX-2. Despite the evidence, the inactivation of the $\mathrm{NF} \kappa \mathrm{B}$ pathway by sulforaphane requires further elucidation to determine its impact as an important molecular chemopreventative mechanism.

The regulation of endogenous receptor expression in selected cells may also be an important chemopreventative mechanism of sulforaphane. For example, sulforaphane has been shown to inhibit the expression of estrogen receptor alpha $(E R \alpha)$ in the human MCF-7 breast cancer cell line due to an inhibition of ER $\alpha$ mRNA transcription as well as due to increased proteosome-mediated degradation (225). These data suggest that sulforaphane has the potential to inhibit cancer cell proliferation caused by aberrant hormone ER receptor expression in MCF-7 cells. In addition, sulforaphane significantly increased the reactivation of $\mathrm{ER} \alpha$ expression in ER-negative breast cancer cells, and was consistently correlated with $\mathrm{ER} \alpha$ promoter hypomethylation and hyperacetylation (185). Treatment of Caco-2 cells with sulforaphane for $48 \mathrm{~h}$ also led to the downregulation of serotonin receptor 5-HT to undetectable levels as compared with the control (182).

The ability of sulforaphane to sensitize drug-resistant cancer cells to tumor necrosis factor-related apoptosisinducing ligand (TRAIL)-induced apoptosis has been demonstrated in multiple studies, with reports demonstrating sulforaphane-enhanced TRAIL-induced apoptosis in human osteosarcoma cells (Saos2 and MG63) and hepatoma cells $(143,182)$. The induction of cell death in various tumor cell lines by sulforaphane was coupled with increased p53, activated caspase- 3 proteins, and decreased hypoxia-inducible factor- $1 \alpha$ activation under hypoxic conditions (which mediates resistance to TRAIL) (123). It was also shown that sulforphane may mediate sensitization to TRAIL-induced apoptosis through the upregulation of death receptor 5 (DR5) mRNA and protein expression (182).

Recently, the ability of sulforaphane to modulate toll-like receptor (TLR) activation and signaling has been implicated as an additional chemopreventive property. TLRs recognize specific patterns derived from invading microorganisms and pathogens, or damaged cells and tissues to elicit the innate and/or adaptive immune response (153). Zhu et al. observed that sulforaphane caused inhibition of TLR3, with the ability to modulate $\mathrm{NF} \kappa \mathrm{B}$ signaling and downstream gene expression, including the downregulation of IL- 8 and TNF- $\alpha$ (320). Sulforaphane has also been reported to form adducts with cysteine residues in the extracellular domain of TLR4, which results in the inhibition of TLR4 dimerization in a thiol-dependent manner (307). In addition, sulforaphane interfered with the binding of lipopolysaccharide to myeloid differentiation 2 (MD2) by its ability to preferentially bind to the cysteine 133 residue in the hydrophobic pocket of MD2 (154). Although this inhibition is important for the attenuation of the inflammatory response (an important factor in the development of cancer), modulation of downstream mechanisms to TLR signaling may also limit the progression of cancer. Specifically, sulforaphane inhibited the expression of intercellular adhesion molecule-1 and vascular cell adhesion molecule-1 through TLR4-dependent pathway in cultured endothelial cells (246). Blocking the expression of adhesion molecules is important in limiting cancer cell invasion and metastasis $(147,178)$.

\section{Targeting Cancer Stem Cells with Sulforaphane}

Most recently, tumor heterogeneity has been considered to arise through the aberrant differentiation of cancer cells, as well as a result of continuing mutagenesis (230). The existence of cancer cells with stem cell-like properties in a number of cancer types has recently been identified $(23,34$, $63,177,209,256)$. It is proposed that the growth of a tumor is driven by a small population of cancer cells, which have the ability to undergo self-renewal, and may be responsible for tumor relapse, metastasis, and resistance (155, 230, 317).

A number of studies have suggested that sulforaphane possesses the capacity to target cancer stem cells through direct and indirect mechanisms, alone or in combination with other anticancer compounds (168). As previously described, 
sulforaphane is able to attenuate $\mathrm{NF} \kappa \mathrm{B}$ activity and nuclear translocation of the $\mathrm{NF} \kappa \mathrm{B}$ subunit, resulting in decreased expression of $\mathrm{NF} \kappa \mathrm{B}$-regulated genes $(125,302)$. Kallifatidis et al. demonstrated the ability of sulforaphane to abrogate the resistance of pancreatic tumor-initiating cells to TRAIL by interfering with TRAIL-activated $\mathrm{NF} \kappa \mathrm{B}$ signaling (133). Specifically, sulforaphane reduced the DNA binding capacity of transactivation-competent $\mathrm{NF} \kappa \mathrm{B}$ dimers that were found in a tumor initiating cell-enriched cell population. Thus, sulforaphane was shown to impair the expression of $\mathrm{NF} \kappa \mathrm{B}$ target genes with antiapoptotic effects.

In addition, the sonic hedgehog ( $\mathrm{SHH}$ ) signaling pathway is linked to $\mathrm{NF} \kappa \mathrm{B}$ signaling, with reports of an overexpression of $\mathrm{SHH}$ activated by $\mathrm{NF} \kappa \mathrm{B}$ in pancreatic cancer (203). After sulforaphane treatment, inhibition of SHH signaling has been demonstrated, and may contribute to the regulation of the self-renewal capacity of human pancreatic cancer stem cells $(167,233)$. In an in vitro model, sulforaphane was shown to inhibit the SHH signaling pathway, and reduced the expression of Smo, Gli1, and Gli2 (233). Sulforaphane was also shown to inhibit the nuclear translocation and transcriptional activity of Gli1 and Gli2 in a dosedependent manner. After treatment for 1 week, the formation of human pancreatic cancer stem cell-derived spheres was significantly inhibited, suggesting the clonogenic depletion of the cancer stem cells. Similarly, sulforaphane treatment resulted in a significant reduction in the tumor growth of orthotopically impanted primary pancreatic cancer stem cells isolated from human pancreatic tumors into the pancreas of mice in vivo (167). Through the modulation of SHH signaling, decreased expression of downstream target genes (i.e., Nanog, Oct-4, VEGF, and ZEB-1) was also demonstrated.

The epithelial-mesenchymal transition (EMT), which is of critical importance in tumorgenesis and metastasis (118), has also been shown to be modulated after sulforaphane treatment with the downregulation of EMT markers, including ZEB-1, Twist-1, and vimentin (267). Consistent with this finding, sulforaphane was shown to inhibit the EMT process via COX2/MMP2,9/ZEB1, Snail, and miR-200c/ZEB1 pathways, and possessed the ability to suppress metastasis in human bladder cancer cells (249). Several studies have also shown that sulforaphane may inhibit the pro-survival PI3K/ Akt pathway, which has been implicated in cellular survival and growth, and resistance $(33,83,253)$. Sulforaphane alone and in combination with quercetin suppressed the growth of pancreatic cancer stem cells derived from pancreatic cancer cell lines in vitro, through the inhibition of the PI3K/Akt and MAPK/ERK pathways (237).

$\beta$-catenin, an important protein subunit of the cadherin protein complex and that functions as an intracellular signal transducer in the Wnt signaling pathway, has been shown to be important in the self-renewal of cancer stem cells and in the EMT process. In the human cervical carcinoma (HeLa) and hepatocarcinoma (HepG2) cell lines, sulforaphane has displayed a capacity to induce the downregulation of $\beta$ catenin (215). Li et al. evaluated the effect of sulforaphane on breast cancer stem cells with profound implications (169). Sulforaphane (1-5 $\mu M)$ decreased aldehyde dehydrogenase (ADH)-positive cell population by $65 \%-80 \%$, and reduced the size and number of primary mammospheres by 8 - to 125 fold and $45 \%-75 \%$, respectively, in vitro. A daily injection with $50 \mathrm{mg} / \mathrm{kg}$ sulforaphane for 2 weeks in nonobese diabetic/severe combined immunodeficient xenograft mice reduced the ADH-positive cell population by $>50 \%$. Sulforphane successfully eliminated breast cancer stem cells in vivo, thereby limiting tumor growth after implantation of primary tumor cells into secondary mice. Through Western blotting analysis and $\beta$-catenin reporter assay results, sulforaphane was shown to promote $\beta$-catenin phosphorylation and its subsequent degradation. It was thus proposed that the inhibition of breast cancer stem cells was caused, at least in part, by the downregulation of the $\mathrm{Wnt} / \beta$-catenin selfrenewal pathway.

Due to the finding that sulforaphane may possess therapeutic potential against cancer stem cells, its use in combination with clinically relevant drugs that limit tumor growth through its toxicity to differentiated stem cells may overcome limitations observed in current cancer management strategies, including resistance and reoccurrence (168). Kallifatidis et al. also demonstrated that sulforaphane enhanced the toxicity of various cytotoxic compounds, including cisplatin, gemcitabine, doxorubicin, and 5-flurouracil, toward pancreatic and prostate cancer stem cells (132). Sulforaphane increased the chemotherapeutic effects on self-renewal and ALDH activity, while limiting toxicity in normal cells. Significantly, the combination therapy abrogated tumor-initiating potential in vivo, with no adverse effects reported. Another study suggested that sulforaphane had the ability to potentiate the drug efficacy of imatinib by limiting leukemia cancer stem cells through the downregulation of $\beta$-catenin (171).

\section{Epigenetic Modulation by Sulforaphane to Exert Anticancer Effects}

The modulation of the epigenome is critical in the development and progression of cancer, contributing to the malignant transformation of cells through the ability to regulate gene expression without modifying the underlying DNA sequence (196). Dysregulated epigenetic processes, including aberrant DNA methylation, histone modifications, and posttranscriptional regulation of gene expression by noncoding microRNA, are implicated in multistage carcinogenesis, and may be regarded as promising targets for cancer prevention and management strategies (18). Dietary isothiocyanates, including sulforaphane and their subsequent metabolites, have displayed a capacity to regulate gene expression through epigenetic mechanisms, with further studies required in order to completely elucidate their impact in cancer chemoprevention (Fig. 6).

In general, the addition of acetyl groups to histones by histone acetyltransferase (HAT) promote gene expression through the ability to create an "open" chromatin conformation, allowing the transcription machinery to access DNA (304). Conversely, removal of acetyl groups by (histone deacetylase enzymes) HDACs results in a "closed" conformation, repressing transcription and inhibiting gene expression. An increase in HDAC activity and expression has been demonstrated in a number of cancer types, and may result in a repression of gene transcription that results in the deregulation of differentiation, cell cycle, and apoptotic mechanisms (68). In addition, important tumor suppressor genes, including $\mathrm{p} 21$, are observed to be a target for HDAC-mediated transcriptional silencing. HDAC inhibition has also been reported to disrupt the cell cycle in the G2 phase, allowing 
FIG. 6. Impact of sulforaphane on DNA methylation and histonemodifying enzymes on the regulation of genes commonly dysregulated during carcinogenesis. Inhibition/ modulation of HDAC and DNMT activity by sulforaphane may lead to the reactivation of epigenetically silenced genes in order to enhance chemoprevention. Further studies are required in order to completely elucidate the significance of sulforaphane in the regulation of epigenetic changes, including its ability to modulate microRNA expression (not illustrated).

cells to prematurely enter the $\mathrm{M}$ phase, as well as to directly interfere with the mitotic spindle checkpoint (235).

HDAC inhibition was first reported by Myzak et al., who observed that sulforaphane increased TOPflash reporter activity without altering protein levels of $\beta$-catenin or HDAC 1 , indicating that the activity of HDAC itself was altered (200). Previous results had shown that TOPflash reporter activity may be used as an indirect measure of HDAC activity, with an increase in reporter activity corresponding to a decrease in HDAC activity in cells (22). In cytoplasmic and nuclear extracts from human embryonic kidney 293 (HEK293) cells treated with sulforaphane, HDAC activity was attenuated compared with untreated cells, global histone acetylation was increased, and activation of TOPflash was observed after its association with acetylated histones H3 and H4 (200). In addition, results from this study displayed the importance of sulforaphane metabolites (sulforaphane- $N$-acetylcysteine,
SFN-NAC, and sulforaphane-cysteine, SFN-Cys) to produce a concentration-dependent inhibition of HDAC activity. It is proposed that SFN-Cys is the ideal dietary HDAC inhibitor, due to its formation during sulforaphane metabolism, and its regeneration from SFN-NAC $(56,57)$. Sulforaphane treatment also markedly increased $\mathrm{p} 21^{\mathrm{Cip} 1 / \mathrm{Waf} 1}$ protein expression due to an increase in acetylated histone $\mathrm{H} 4$ bound to the promoter region of $p 21$. Similar results were observed in three prostate epithelial cell lines (BPH-1, LNCap, and PC3) with HDAC inhibition significant at a concentration of $15 \mu \mathrm{M}$ sulforaphane (199). Interestingly, $15 \mu M$ sulforaphane also increased acetylated histone $\mathrm{H} 4$ association with the proapoptotic bax promoter and regulated bax mRNA expression, indicating that sulforaphane may directly mediate bax induction through chromatin remodeling. After a single oral gavage dose of sulforaphane in $\mathrm{Apc}^{\mathrm{min}}$ mice, significant inhibition of HDAC activity in the mouse colonic mucosa was 
observed in vivo (198). HDAC activity was decreased by $50 \%$ with SFN-NAC and by $\sim 65 \%$ with sulforaphane in comparison to untreated mice. Both sulforaphane and its metabolite produced an increase in acetylated histone $\mathrm{H} 3$ and histone $\mathrm{H} 4$ in the colon, with a $\sim$ two-fold increase at both the 6 and $24 \mathrm{~h}$ time points before returning to baseline levels. In $\mathrm{Apc}^{\mathrm{min}}$ mice, sulforaphane suppressed tumor multiplicity, with the average tumor yield lowered by $\sim 50 \%$ in all regions of the intestine. Similar to the results from the in vitro studies, sulforaphane induced global histone acetylation, with a marked increase in acetylated histone $\mathrm{H} 2$ associated with the promoter regions of both the $p 21$ and bax genes. Moreover, in human subjects, HDAC acitivity was significantly inhibited in the peripheral blood mononuclear cells of all three subjects, with detection at $3 \mathrm{~h}$ post consumption of $68 \mathrm{~g}$ broccoli sprouts (201). In two of the subjects, HDAC inhibition was observed at the $6 \mathrm{~h}$ time point, with levels returning to baseline by $24-48 \mathrm{~h}$ post consumption. In the third subject, HDAC activity at baseline was lower than expected, and, therefore, the highest HDAC activity was observed at the $48 \mathrm{~h}$ time point. In continuation, healthy subjects consumed either the $68 \mathrm{~g}$ of broccoli sprouts or six supplements $(\sim 3 \mathrm{~g}$ of freeze-dried broccoli sprouts) to assess isothiocyanate metabolite levels and HDAC activity (44). In addition to confirming that active myrosine is required for sulforaphane metabolism, inhibition of HDAC activity was measured and statistically significant at 12 and $48 \mathrm{~h}$ post consumption of either the sprouts or the supplementation, when compared with baseline HDAC activity. Further human studies are required in order to determine the significance of HDAC inhibition in disease, and the ability to provide therapeutic benefit via decreased HDAC activity.

Studies involved in the evaluation of sulforaphane as an HDAC inhibitor, and those aimed at providing insights into the mechanisms associated with sulforaphane-regulated inhibition of HDAC activity, have focused on the roles of HDAC3 and HDAC6 as important targets $(43,89,223,224)$. After the incubation of HCT116 human colon cancer cells with $15 \mu M$ sulforaphane, a significant reduction in HDAC1, HDAC2, HDAC3, and HDAC8 was observed compared with vehicle-treated cells at $36 \mathrm{~h}$ post administration (223). Among the class I HDACs, HDAC3 protein expression was the most susceptible to sulforaphane-induced loss, with cells treated with $35 \mu M$ reporting a reduction of HDAC3 expression by more than $95 \%$. HDAC4 and HDAC6 were also shown to be reduced after $24 \mathrm{~h}$. Overexpression of either HDAC3 or HDAC6 was shown to inhibit sulforaphaneinduced histone H4-K12 acetylation (important in the regulation of gene expression). The silencing mediator for retinoid and thyroid hormone receptors (SMRT) was phosphorylated in the nucleus within $6 \mathrm{~h}$ of sulforaphane treatment, and was, subsequently, implicated in HDAC3 turnover mechanisms. Sulforaphane-induced association of HDAC3/ SMRT complexes coincided with increased binding of HDAC3 to 14-3-3 and peptidyl-prolyl cis/trans isomerise 1 (PIN1), ultimately directing HDAC3 for degradation. Further investigations led to the finding that sulforaphane metabolites may interact with the allosteric site between HDAC3 and SMRT, providing new insights into the dissociation of HDAC3/SMRT complex in colon cancer cells (224). Sulforaphane and its metabolites were also shown to alter the acetylation status of key DNA repair protein CtIP, with a significant increase at $6 \mathrm{~h}$ post treatment. The induction of double-strand breaks (measured by $\gamma \mathrm{H} 2 \mathrm{AX}$ immunofluorescence) increased after sulforaphane treatment of cancer cells, but failed to effect noncancer controls. Collectively, this evidence suggests that sulforaphane may also compromise DNA repair mechanisms in cancer cells with selectivity.

In prostate cancer cells, sulforaphane treatment increased acetylation of two HDAC6 target proteins: heat shock protein 90 (HSP90) and $\alpha$-tubulin (89). Despite unchanged HDAC6 protein levels at early time points, HSP90 became hyperacetylated and dissociation of the androgen receptor (AR) from HSP90 was observed. At later time points, AR protein levels declined after sulforaphane treatment, indicating the ability of sulforaphane to destabilize AR. Importantly, incubation of recombinant HDAC6 with sulforaphane inhibited HDAC6 deacetylase activity, with sulforaphane leading to reduced HDAC6 protein levels at the $16 \mathrm{~h}$ time point in prostate cancer cells. Clarke et al. demonstrated the ability of sulforaphane to preferentially induce apoptosis and cell cycle arrest in the benign prostatic hyperplasia (BPH-1) cell line and the LNCap and PC3 prostate cancer cell lines, as well as the induction of phase II enzymes (43). At $24 \mathrm{~h}$ post incubation, HDAC inhibition was observed in all cells lines, with LNCap cells with a significant inhibition compared with healthy controls. By the $48 \mathrm{~h}$ time point, sulforaphane induced sustained HDAC inhibition in all cancer cell lines. Specifically, HDAC2 and HDAC3 protein levels were decreased in BPH-1 cells and HDAC3 in both LNCap and PC3 cell lines at $48 \mathrm{~h}$ post treatment. HDAC4 protein expression was decreased in all cell lines at one or both time points. HDAC6 showed the most significant and consistent decrease in protein levels in all prostate cancer cell lines at both 24 and $48 \mathrm{~h}$ time points, with this decrease not observed in healthy prostate cells (PrEC). Interestingly, overexpression of HDAC6 protected PC3 cells from the sulforaphaneinduced decrease in cell viability, indicating the likely importance of HDAC6 in sulforaphane-mediated chemoprevention in prostate cancer.

The modulation of patterns in DNA methylation are observed during cancer development and progression, and is characterized by global- and site-specific DNA hypomethylation as well as gene-specific promoter hypermethylation $(17,220)$. While DNA hypomethylation may contribute to genome instability and increased expression of oncogenes, DNA hypermethylation may lead to the inhibition of tumor suppressor genes, transcription factors, and genes involved in cell cycle regulation and apoptosis. DNA methylation patterns are mediated by DNA methyltransferases (DNMTs), and an overexpression of DNMTs is observed in a number of cancers, including leukemic, gastric, lung, and prostate camcer $(69,172,193,195)$.

Meeran et al. first observed the significant inhibition of DNMT1 and DNMT3a expression by sulforaphane in a dosedependent manner in human breast cancer cells (MCF-7 and MDA-MB-231 cell lines), and to a lesser extent in normal MCF10A cells (186). Specifically, $10 \mu M$ sulforaphane in 6 days inhibited DNMT1 and DNMT3a expression by $48 \%$ and $78 \%$, respectively. Ultimately, this study aimed at assessing the telomerase activity and human telomerase reverse transcriptase ( $h T E R T$; important catalytic component of telomerase) in human breast cancer, and the effect of sulforaphane on hTERT expression. Sulforaphane treatment led to the 
significant downregulation of hTERT in breast cancer cells, with a negligible inhibitory activity in the normal control, indicating specificity. Investigation into the molecular mechanisms of sulforaphane-induced inhibition of hTERT expression found significant demethylation of CpGs in the CTCF binding region on the $h T E R T$ regulatory region in both breast cancer cell lines after treatment with sulforaphane. It is known that the transcription repressor CTCF binds to exon 1 of the hTERT gene and, in turn, reduces the expression of $h T E R T$. Treatment with sulforaphane was shown to increase CTCF binding to the hTERT exon 1 binding site to subsequently inhibit $h T E R T$ expression. It is suggested that the downregulation of $h T E R T$ expression facilitated the induction of cellular apoptosis in the cancer cell lines.

Similar results in prostate cancer cell lines established the ability of sulforaphane to significantly decrease DNMT1 and DNMT3a mRNA expression (113). Decreased global methylation in LNCap cells after treatment with sulforaphane for $24 \mathrm{~h}$ was also observed. In prostate cancer, cyclin D2 silencing has been observed to be associated with cancer progression, with restoration of cyclin D2 inducing cell death in prostate LNCap cancer cells (149). Investigation of the promoter methylation status of cyclin D2 in prostate cancer cells reported a significant decrease in methylated $\mathrm{CpG}$ sites in the region after sulforaphane incubation. In particular, sulforaphane significantly decreased methylation at the binding site of the c-Myc transcription factor (observed to be hypermethylated in untreated tumor cells). Due to the demethylation of the cyclin D2 promoter, sulforaphane increased cyclin D2 mRNA expression in a dose-dependent manner. Conversely, treatment of colon cancer cells with sulforaphane in varying concentrations failed to impact abnormal methylation patterns in critical genes involved in colon carcinogenesis in vitro (16). However, Barrera et al. suggest that their finding may be due to heterogeneity in cancer, with some cell lines and/or tissue affected by sulforaphaneinduced gene-specific methylation, while others are more resistant.

Recently, assessment on the DNA methylation profile in normal prostate epithelial cells (PrEC), androgen-dependent (LNCap) and androgen-independent (PC3) prostate cancer cells was shown to be altered depending on the cell line (298). Untreated LNCap and PC3 cells had significantly higher baseline expression of DNMT1, DNMT3a, and DNMT3b compared with untreated PrEC cells. While sulforaphane treatment of PrEC and LNCap cells decreased DNMT1 and DNMT3b gene expression, the expression of all three DNMTs was downregulated in the PC 3 cell line. Hierarchical clustering analysis showed that $64 \%$ of the 54,876 probes and $49 \%$ of the 78,272 probes in LNCap cells displayed hypermethylation relative to PrEC cells (298). This represented 10,315 and 8013 genes differentially methylated in LNCap and PC3 genes, respectively, compared with the normal control. Functional annotation analyses indicated that genes with altered methylation profiles in the prostate cancer cell lines were genes involved in cancer progression, and associated with cell migration, cell adhesion, cell-cell signalling, as well as transcription regulation (298). After sulforaphane treatment, 2472 (in PrEC cells), 3508 (in LNCap cells) and 6778 (in PC3 cells) differentially methylated genes were detected. Interestingly, sulforaphane altered methylation in distinct sets of genes in each of the cell lines (298). In PrEC cells, genes involved in transcription, apoptosis, and chromatin organization/modification were altered with sulforaphane treatment. Functional annotation analysis in LNCap cells found that two general categories of genes were affected: (1) genes associated with cell movement, including cell migration, adhesion, and localization, and (2) genes associated with the immune response, including inflammation, leukocyte activation, and immune regulation. Sulforaphane treatment in PC3 cells altered genes shared both PrEC and LNCap cell lines, including those involved in transcription, apoptosis, cell migration, and immune response (298). Perhaps the most interesting finding was the reversal of the methylation profiles of 1509 (14.6\%) genes (out of 10,315 genes) after sulforaphane treatment in LNCap cells. Many of these genes are known to be dysregulated or are highly involved in cancer progression, including transforming growth factor- $\beta 1$ receptor type I (TGFBR1), C-C chemokine receptor type 4 (CCR4), C-X-C chemokine receptor receptor type 4 (CXCR4), and cysteine-rich angiogenic inducer 61 (CYR61). Overall, this study demonstrated the capacity of sulforaphane to modulate DNA methylation and regulate gene expression in order to act as a chemopreventive compound in prostate cancer in vitro (298). Further studies are required in order to enhance understanding of the epigenetic modulatory mechanisms of sulforaphane.

As previously described, sulforaphane was first identified as a potent inducer of phase II detoxifying enzymes via the disruption of Nrf2-Keap1 interactions, and an increased translocation and therefore activation of $\mathrm{Nrf} 2$ (117, 148, 206). Zhang et al. aimed at investigating the potential of sulforaphane to reactive the expression of Nrf2 through epigenetic regulation (310). In prostate cancer TRAMP C1cells, Nrf2 transcription was significantly inhibited when the first five $\mathrm{CpG}$ regions of the Nrf2 gene promoter were hypermethylated (309). Treatment with sulforaphane (1.0 and $2.5 \mu M$ ) reduced the level of methylation to $56.0 \%$ and $38.7 \%$, respectively. Demethylation of the promoter region was shown to result in the transcription activation of Nrf2, with increased mRNA and protein expression measured. This study also demonstrated decreased protein levels of DNMT1 and DNMT3a after sulforaphane treatment in a dose-dependent manner in TRAMP C1 cells. In addition, sulforaphane decreased protein levels of HDAC1, HDAC4, HDAC5, and HDAC7, indicating HDAC inhibitory activity. The global level of acetylated histone 3 was also highly induced by sulforaphane treatment. Comparable to this study, sulforaphane significantly inhibited 12-O-tetradecanoylphorbol-13-acetate (TPA)-induced mouse skin epidermal (JB6) transformation via its ability to enhance nuclear translocation of $\mathrm{Nrf} 2$ and increase expression of Nrf2-target antioxidant genes, including HO-1, NQO1, and UGT1A1 (273). Bisulfite sequencing determined that $15 \mathrm{CpG}$ regions in the Nrf2 gene promoter were hypermethylated in the untreated cells. The ratio of methylated $\mathrm{CpG}$ regions was decreased to $68.7 \%$ by $2.5 \mu M$ sulforaphane. Furthermore, sulforaphane decreased the protein expression of DNMT1, DNMT3a, and DNMT3b in a concentration-dependent manner in TPA-induced JB6 cells post treatment ( 5 day period). In addition, treatment with either 2.5 or $5.0 \mu M$ sulforaphane significantly inhibited relative HDAC activity by $50 \%$, with reduced protein expression levels of HDAC1, HDAC2, HDAC3, and HDAC4 observed. These findings suggest that sulforaphane has the ability to 


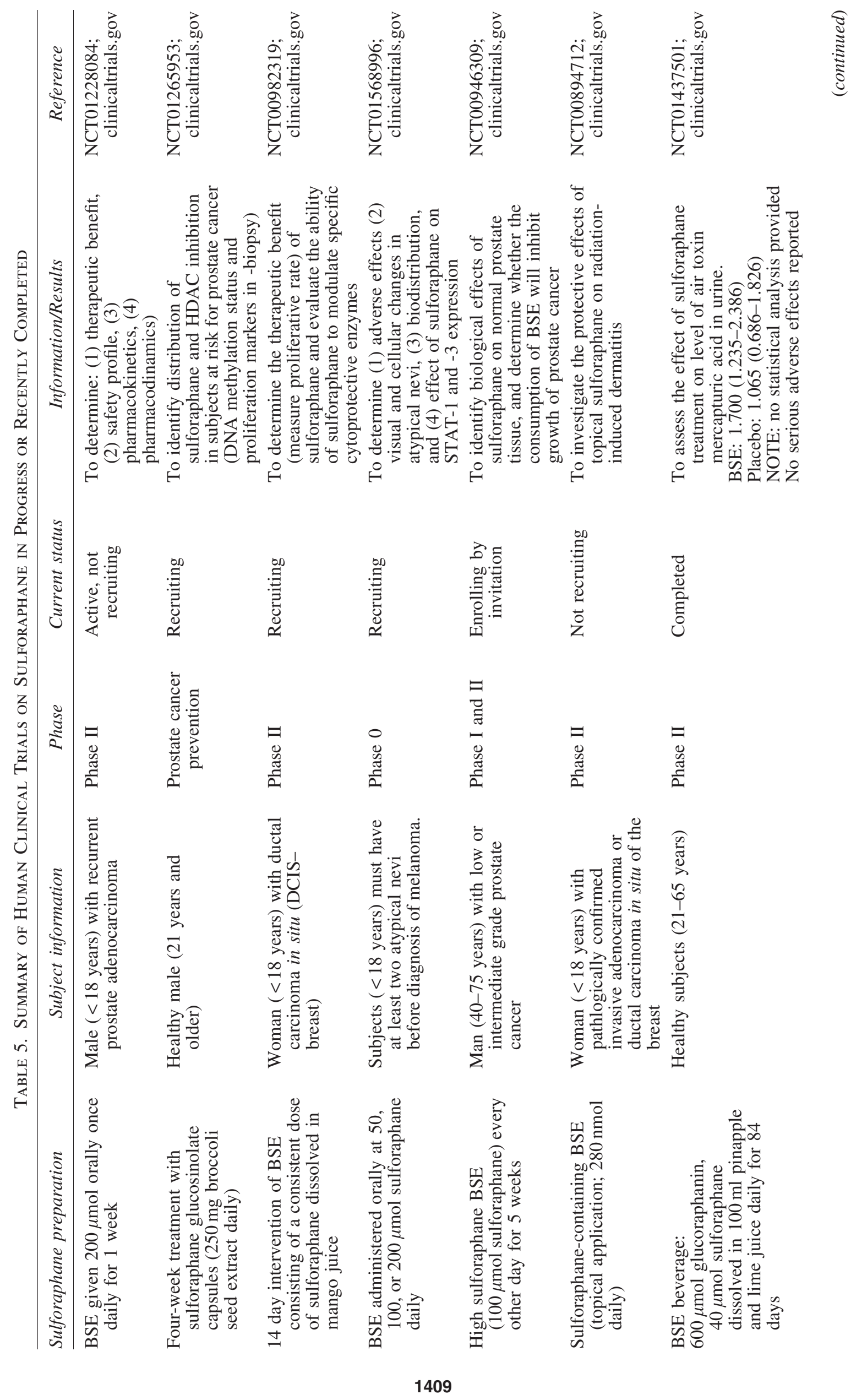




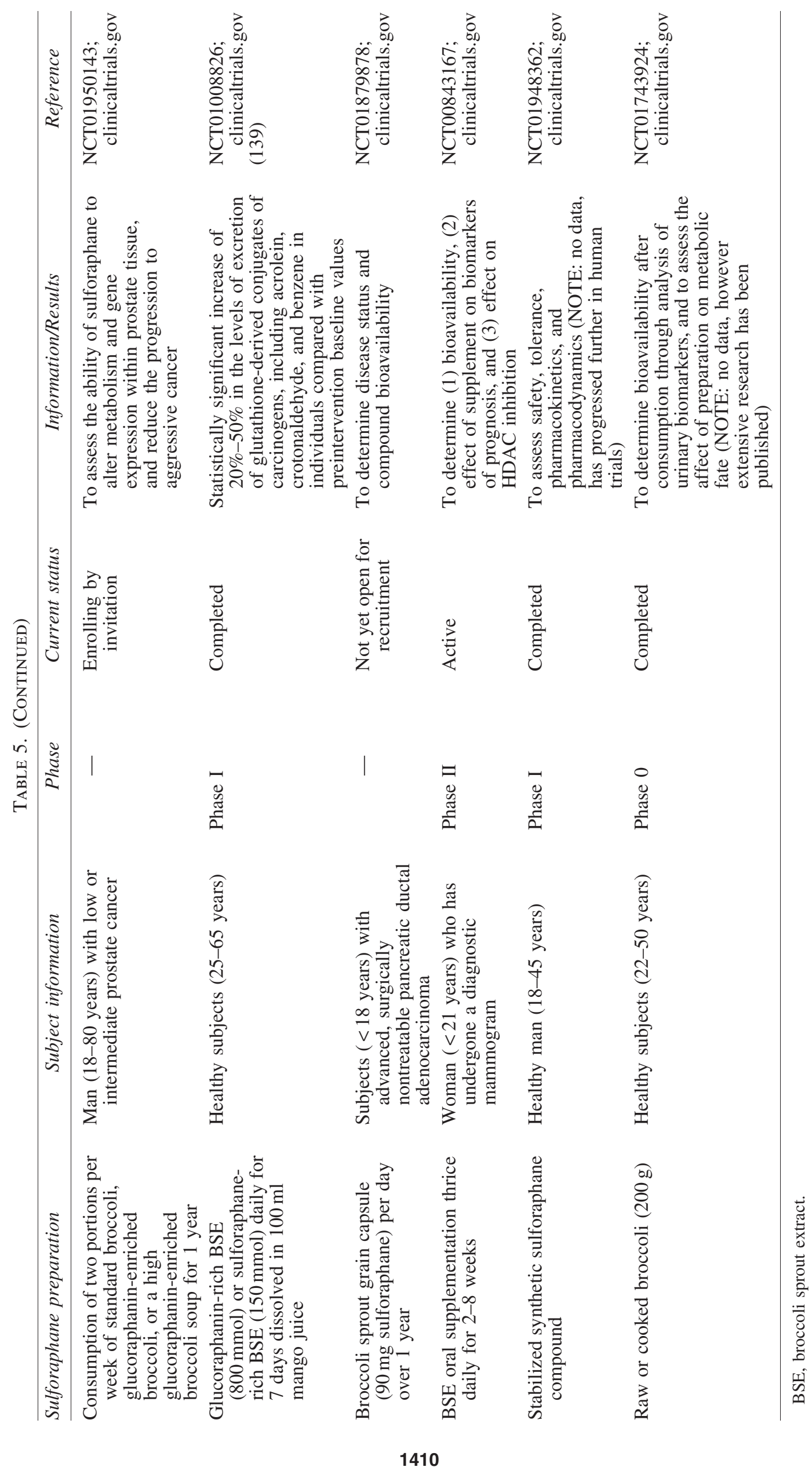


restore expression and activation of Nrf2 via a number of epigenetic regulatory mechanisms.

MicroRNAs (miRNAs) are short noncoding RNAs, 18 to 25 nucleotides in length, that regulate gene expression posttranslation through binding to $3^{\prime}$ untranslated regions of target mRNA (261). Bioinformatic studies predict that miRNAs regulate almost $30 \%$ of all mammalian genes, and are dysregulated in the majority of human cancers (29). The assessment of sulforaphane in the regulation of miRNA expression is limited in the literature, and further investigation is required in order to complete understanding. The treatment of nontransformed human colonic epithelial cells with sulforaphane resulted in significant changes in miRNA expression profiles (15 upregulated and three downregulated) as analyzed by quantitative real-time reverse-transcription polymerase chain reaction (260). Global downregulation of miRNA expression was demonstrated from colorectal tumor tissue. Focusing on miRNA expression changes in both cell lines, the upregulation of miR-23b and miR-27b was significant due to a previous observation of decreased levels in clinical tumor tissue (241). MiR-23b has been shown to be critical in tumor suppression and regulation of EMT $(30,311)$. Conversely, downregulation of miR-155 (a well-known oncogenic miRNA) by sulforaphane was also identified as important (280). In addition, the expression of miR-200c, which has been identified in the regulation of EMT in human bladder cancer (3), was significantly induced by sulforaphane in the human bladder T24 cancer cell line (248).

In basal-like ductal carcinoma in situ (DCIS) lesions, 68 miRNAs were significantly dysregulated in tissue compared with controls via microarray analysis (166). The downregulation of miRNA-140 expression was indicated to be the most reproducible miRNA signature in the lesions that was implicated in tumor suppression. In a subsequent analysis of 22 DCIS samples, Li et al. observed the miR-140 loss in all tumors irrespective of histological grade and breast malignancy type. Also demonstrated was the finding that the 72 miRNAs were found to be differentially expressed between normal mammary epithelial stem cells (isolated from MCF$10 \mathrm{~A}$ cells) and stem-like cells isolated from the DCIS lesions (denoted as MCF10DCIS cells). Interestingly, miR-140 was one of the most significantly downregulated in cancer stemlike cells, with a 13.55-fold difference compared with normal stem cells. Treatment of DCIS tissue with sulforaphane was shown to activate miR-140 expression and downregulation of SOX9 and ALDH1 (important in stem cell regulation, and targets of miR-140 in DCIS stem-like cells), resulting in a decrease in stem-like cell frequency in vitro and a significant inhibition of tumor growth in vivo. Further characterization of exosomal trafficking of a stem-like population in basallike DCIS lesions resulted in the finding that the exosomal miRNA expression pattern in DCIS stem-like cells possessed an inverse trend in comparison to nontumorigenic MCF10A stem cells (165). For example, miR-21 and miR-29 were secreted in high levels in the DCIS stem-like cells, with normal stem cells secreting much lower levels. In the context of sulforaphane, treatment resulted in increased exosomal miR-140 (with the capacity to transfer into breast cancer cells) and decreased miR-21 and miR-29. Collectively, this evidence suggests that sulforaphane may have the capacity to inhibit DCIS stem cell signaling in neighboring cells through epigenetic mechanisms by increasing exosomal miR-140 secretion in the tumor microenvironment.

\section{Sulforaphane in Human Clinical Trials}

Multiple commercially developed sulforaphane supplements are currently available; however, the difficulty in manufacturing a potent and bioavailable formula has proved to be difficult, with an intrinsic instability of the sulforaphane molecule preventing this method of delivery (64). Manufacturing a sulforaphane-yielding supplement requires the ability to retain both the glucoraphanin precursor and the myrosinase enzyme for subsequent metabolism and transformation to the bioactive isothiocyanate (111). A number of phase I and II clinical trials on sulforaphane, however, are in progress or have been completed to assess its safety, tolerance, pharmacokinetics, and therapeutic benefit in healthy human subjects and in the context of cancer (Table 5).

Residents of Qidong are at high risk for the development of hepatocellular carcinoma, which was in part due to long-term exposure to aflatoxin-contaminated food, and the airborne carcinogen, phenanthrene (67). An inverse association between the level of sulforaphane metabolites and carcinogenrelated markers, including aflatoxin-DNA adducts, was demonstrated (139). It was also reported that sulforaphane increased the excretion of airborne pollutants in individuals consuming the broccoli extract beverage, with the administration of a broccoli sprout-infused beverage containing $400 \mu M$ glucoraphanin nightly for 2 weeks causing no adverse effects and being well tolerated in 200 subjects (140). Although promising, results displayed significant variability in the bioavailability of the active compound. Consistent with this finding, Fahey et al. found that administration of a sulforaphane-rich broccoli sprout extract to two distinct populations (Chinese and Baltimoreans) resulted in varied bioavailability between individuals in both populations, ranging from $1 \%$ to $40 \%$ (72). In a recent intervention study, the total sulforaphane metabolite concentration in plasma was the highest $(>2 \mu M)$ at $3 \mathrm{~h}$ in human subjects who consumed fresh broccoli sprouts $(40 \mathrm{~g})$ in the first phase of study, compared with that measured after administration of a commercially available broccoli supplementation in the second phase (42).

A randomized, placebo-controlled double-blind Phase I clinical trial involving healthy volunteers and the administration of glucoraphanin or isothiocyanate as the sulforaphane source examined parameters of safety, tolerance, and pharmacokinetics (250). No significant toxicity was observed with the dose concentrations administered in this study. Although the plasma concentration of total bioactive sulforaphane may be measured in order to provide a crude estimate of bioavailability and therapeutically significant dosage, accumulation within the tumor site itself may not be significant. For example, a pilot study detected an accumulation of sulforaphane in human breast tissue after consumption of broccoli extract containing $200 \mu M$ sulforaphane $\sim 1 \mathrm{~h}$ before elective reduction mammoplasty (51). Mean epithelial-/ stromal-enriched breast tissue dithiocarbamate concentration was $1.45 \pm 1.12 \mathrm{pmol} / \mathrm{mg}$ in the right breast, and $2.00 \pm$ $1.95 \mathrm{pmol} / \mathrm{mg}$ in the left breast. In comparison, the plasma concentration post sulforaphane administration was measured at $0.92 \pm 0.72 \mu M$. 
Future Directions and Combinatorial Cancer Management Strategies, Including Sulforaphane

Although the chemopreventive properties of sulforaphane have been widely investigated and extensively reported, the difficulty in the administration of a dose that may confer therapeutic significance limits its potential for clinical use. In addition, the estimated consumption required to observe benefits in limiting cancer development and progression has been shown to be unrealistic in the average diet. Limitations in the bioavailability of the compound after administration and/or consumption may also become problematic in human trials as genetic variance and patient compliance become factors. The use of a combination of anticancer compounds that affect different functional pathways may possess the capacity to generate additive or synergistic activity. In theory, this is an attractive approach for the prevention and/or treatment of complex disease, including cancer.

Current chemotherapeutic agents fail to adequately treat malignancy with multivariable dose-restricting factors, including systemic toxicity and multi-drug resistance limiting therapeutic benefits and long-term remission rates. Interestingly, a number of studies have aimed at using sulforaphane in combination with a range of cytotoxic compounds in order to enhance drug efficacy, and, therefore, limit adverse effects observed in chronic administration and high concentration regimens. To demonstrate, sulforaphane was shown to enhance the antitumor activity of oxaliplatin and synergistically activate apoptotic pathways in the colorectal cancer cell line, Caco-2 (135). Fimognari et al. investigated the effects of sulforaphane in combination with doxorubicin on cell viability and apoptosis in fibroblasts characterized by a different p53 status (wild-type, knockout, and with a mutation at codon 220) $(79,80)$. This mutation has been implicated in reduced efficacy and drug resistance in osteosarcomas and breast cancer treated with doxorubicin $(28,87)$. Sulforaphane was shown to restore chemosensitivity and to induce apoptosis in doxorubicin-resistant p53 mutated and p53 knockout cells, irrespective of p53 status. The induction of apoptosis was caspase- 3 dependent and caspase- 8 independent. Interestingly, proliferation of salivary gland adenoid cystic carcinoma high metastatic cell line (ACC-M) and low metastasis cell line (ACC-2) observed to be relatively resistant to a classic chemotherapeutic agent, 5-fluroracil, was inhibited with a synergistic combination using sulforaphane (294). A decreased expression of $\mathrm{NF} \kappa \mathrm{B}$ p 65 protein was also demonstrated, with results more significant in ACC-M cells. Although effective in acute promyelocyctic leukemia (APL), arsenic trioxide fails to adequately treat non-APL blood cancers (65). Significantly, sulforaphane enhanced arsenic trioxide-mediated cytotoxicity and apoptosis in a panel of leukemic cell lines, with a dramatic increase in the number of ROS compared with treatment with either agent alone. Continuing with this combination, Doudican et al. co-treatment of multiple myeloma cells resulted in elevated expression of the molecular chaperone HSP90, along with increased protein kinase RNA-like endoplasmic reticulum kinase (PERK), and important makers of unfolded protein response (UPR) activation (66). Sulforaphane in combination with arsenic trioxide effectively disrupted protein homeostasis through the production of ROS and induction of apoptotic processes. Synergistic effects in pancreatic cancer stem cells were demonstrated when sulforaphane was administered in combination with sorafenib (multikinase inhibitor in clinical trials) (227). It was proposed that these effects were mediated by the reduction of sorafenib-induced $\mathrm{NF} \kappa \mathrm{B}$ binding by sulforaphane. Although treatment with sulforaphane at varying concentrations resulted in a dose- and time-dependent decrease in cell viability of MCF-7 cells, a combination of sulforaphane and gemcitabine demonstrated the capacity of sulforaphane to enhance the growth inhibitory effects of gemcitabine at sub-lethal doses (116). Administration of sub-lethal doses of sulforaphane $(5-10 \mu M)$ when used in various combinations with lower doses of gemcitabine (5$10 \mathrm{~m} M$ ) resulted in a decrease in cell viability that was more pronounced than either of the compounds alone and the combination index (CI) was found to be $<1$, indicting synergistic effects.

In addition, interactions with other known chemopreventive and antioxidant dietary components have also observed synergistic activity after administration in a number of models and systems. For example, the administration of sulforaphane and resveratrol (polyphenolic compound) inhibited cell proliferation and migration, reduced cell viability, induced lactate dehydrogenase release, decreased pro-survival Akt phosphorylation, and increased caspase-3 activation in human U251 glioma cells (126). A combination of sulforaphane and the flavonoid apigenin was shown to modulate gene expression of phase II detoxifying enzymes (including GST and UGT) in the human epithelial colorectal adenocarcinoma cell line, Caco-2 (275). This combination resulted in a synergistic induction of UGT1A1 mRNA by approximately 12-fold. The indole, 3,3'-diindolylmethane (DIM) also derived from cruciferous vegetables has been shown to have cytostatic mechanisms in human colon cancer cell lines (213). In this same study, sulforaphane $(10 \mu M)$ in combination with DIM $(10 \mu M)$ resulted in strong G2/M cell cycle arrest, which was not observed with either compound alone. Nair et al. also demonstrated a synergistic effect after administration of sulforaphane and the catechin epigallocatechin-3-gallate in HT-29 AP-1 human colon carcinoma cells (202). This combination dramatically enhanced transcriptional activation of the Ap-1 reporter, with analysis finding that the CI was $<1$. Cell viability assays showed that low-dose combinations decreased cell viability to $70 \%$, and to $40 \%$ with high-dose combinations at $48 \mathrm{~h}$ post treatment. Pretreatment with $100 \mathrm{ng} / \mathrm{ml}$ of TSA (a potent HDAC inhibitor) potentiated (by 88 -fold) the synergism observed with the low-dose combination on the AP-1 reporter transcriptional activation. Pancreatic stem cells and their self-renewal capacity may also be modulated with a combination of sulforaphane and the dietary polyphenol, quercetin $(267,319)$. The synergistic effect of this combination has also been observed in melanoma B16F10 cells, with the suppression of proliferation and migration due to an implicated decrease in MMP-9 expression (221).

Recent data published by Grandhi et al. reported a novel combinatorial nano-based delivery of chemopreventative agents in the suppression of pancreatic carcinogenesis induced by $N$-nitroso-bis(2-oxopropyl)amine in hamsters (95). A combination of aspirin and curcumin in a solid lipid nanoparticle formulation, and sulforaphane in solution was administered to hamsters by daily oral gavage, which resulted in a decrease in the effective inhibitory dosages by a factor of 10 
as compared with these compounds in free forms. This combination of chemopreventive compounds reduced tumor incidence, tumor multiplicity, and severity of histologic lesions.

\section{Conclusion}

The importance of a diet that is rich in cruciferous vegetable and the role of isothiocyanates, including sulforaphane, in promoting good health has been extensively studied and consistently demonstrated in a wide variety of models and systems. Understanding the phylogeny of glucosinolateproducing plants, in conjunction with the molecular genetics of the Brassicaceae family may enable us to further enhance bioavailability of the bioactive compounds through the development of cultivars with significantly higher amounts of glucoraphanin. Bioavailability and therefore pharmacokinetics of sulforaphane are also dependent on a range of other factors, including active myrosinase content, preparation, and human genetic patterns. Although commercially available as a supplement, sulforaphane has yet to be FDA approved for the treatment of human disease, including cancer. However, the chemopreventive properties of sulforaphane, and its capacity to be selectively toxic to malignant cells and impart these effects through a number of mechanisms, provide rationale to completely elucidate and evaluate its potential as an anti-cancer compound alone, and in combination with clinically relevant therapeutic and management strategies.

\section{Acknowledgments}

The support of the Australian Institute of Nuclear Science and Engineering (AINSE) is acknowledged. TCK was the recipient of AINSE awards. TCK was supported by an Australian Research Council Future Fellowship, and the Epigenomic Medicine Laboratory was supported by McCord Research. This study was supported in part by the Victorian Government's Operational Infrastructure Support Program.

\section{Author Disclosure Statement}

Epigenomic Medicine Laboratory (TCK) receives funding from McCord Research, which has a commercial interest in sulforaphane. Stephanie Tortorella, Simon G Royce, and Paul V Licciardi have no conflict of interest.

\section{References}

1. Abel EL, Boulware S, Fields T, McIvor E, Powell KL, DiGiovanni J, Vasquez KM, and MacLeod MC. Sulforaphane induces phase II detoxication enzymes in mouse skin and prevents mutagenesis induced by a mustard gas analog. Toxicol Appl Pharmacol 266: 439-442, 2013.

2. Abercrombie JM, Farnham MW, and Rushing JW. Genetic combining ability of glucoraphanin level and other horticultural traits of broccoli. Euphytica 143: 145-151, 2005.

3. Adam L, Zhong M, Choi W, Qi W, Nicoloso M, Arora A, Calin G, Wang H, Siefker-Radtke A, McConkey D, BarEli M, and Dinney C. miR-200 expression regulates epithelial-to-mesenchymal transition in bladder cancer cells and reverses resistance to epidermal growth factor receptor therapy. Clin Cancer Res 15: 5060-5072, 2009.

4. Agyeman AS, Chaerkady R, Shaw PG, Davidson NE, Visvanathan K, Pandey A, and Kensler TW. Tran- scriptomic and proteomic profiling of KEAP1 disrupted and sulforaphane-treated human breast epithelial cells reveals common expression profiles. Breast Cancer Res Treat 132: 175-187, 2012.

5. Aires A, Rosa E, and Carvalho R. Effect of nitrogen and sulfur fertilization on glucosinolates in the leaves and roots of broccoli sprouts (Brassica oleracea var. italica). $J$ Sci Food Agric 86: 1512-1516, 2006.

6. Al-Shehbaz I, Navarro E, and Cano A. Aschersoniodoxa peruviana (Brassicaceae), a remarkable new species from Peru and a synopsis of the genus. Kew Bull 67: 483, 2012.

7. Ambrosone CB, McCann SE, Freudenheim JL, Marshall JR, Zhang Y, and Shields PG. Breast cancer risk in premenopausal women is inversely associated with consumption of broccoli, a source of isothiocyanates, but is not modified by GST genotype. J Nutr 134: 1134-1138, 2004.

8. Annema N, Heyworth JS, McNaughton SA, Iacopetta B, and Fritschi L. Fruit and vegetable consumption and the risk of proximal colon, distal colon, and rectal cancers in a case-control study in Western Australia. J Am Diet Assoc 111: 1479-1490, 2011.

9. Araki R, Hasumi A, Nishizawa OI, Sasaki K, Kuwahara A, Sawada Y, Totoki Y, Toyoda A, Sakaki Y, Li Y, Saito $\mathrm{K}$, Ogawa T, and Hirai MY. Novel bioresources for studies of Brassica oleracea: identification of a kale MYB transcription factor responsible for glucosinolate production. Plant Biotechnol J 11: 1017-1027, 2013.

10. Armstrong RN. Glutathione S-transferases: reaction mechanism, structure, and function. Chem Res Toxicol 4: 131-140, 1991.

11. Bacon JR, Williamson G, Garner RC, Lappin G, Langouët $\mathrm{S}$, and Bao Y. Sulforaphane and quercetin modulate PhIPDNA adduct formation in human HepG2 cells and hepatocytes. Carcinogenesis 24: 1903-1911, 2003.

12. Bahadoran Z, Mirmiran P, Hosseinpanah F, Hedayati M, Hosseinpour-Niazi S, and Azizi F. Broccoli sprouts reduce oxidative stress in type 2 diabetes: a randomized doubleblind clinical trial. Eur J Clin Nutr 65: 972-977, 2011.

13. Baik HY, Juvik J, Jeffery E, Wallig M, Kushad M, and Klein B. Relating glucosinolate content and flavor of broccoli cultivars. J Food Sci 68: 1043-1050, 2003.

14. Bailey CD, Koch MA, Mayer M, Mummenhoff K, O'Kane Jr SL, Warwick SI, Windham MD, and AlShehbaz IA. Toward a global phylogeny of the brassicaceae. Mol Biol Evol 23: 2142, 2006.

15. Barcelo S, Gardiner JM, Gescher A, and Chipman JK. CYP2E1-mediated mechanism of anti-genotoxicity of the broccoli constituent sulforaphane. Carcinogenesis 17: 277-282, 1996.

16. Barrera LN, Johnson IT, Bao Y, Cassidy A, and Belshaw NJ. Colorectal cancer cells Caco-2 and HCT116 resist epigenetic effects of isothiocyanates and selenium in vitro. Eur J Nutr 52: 1327-1341, 2013.

17. Baylin SB and Jones PA. A decade of exploring the cancer epigenome - biological and translational implications. Nat Rev Cancer 11: 726-734, 2011.

18. This reference has been deleted.

19. Beilstein MA, Al-Shehbaz IA, and Kellogg EA. Brassicaceae phylogeny and trichome evolution. Am J Bot 93: 607-619, 2006.

20. Benedict AL, Knatko EV, and Dinkova-Kostova AT. The indirect antioxidant sulforaphane protects against thiopurinemediated photooxidative stress. Carcinogenesis 33: 24572466, 2012. 
21. Benito E, Obrador A, Stiggelbout A, Bosch FX, Mulet M, Munoz N, and Kaldor J. A population-based case-control study of colorectal cancer in Majorca. I. Dietary factors. Int J Cancer 45: 69-76, 1990.

22. Billin AN, Thirlwell H, and Ayer DE. $\beta$-Catenin-Histone deacetylase interactions regulate the transition of LEF1 from a transcriptional repressor to an activator. Mol Cell Biol 20: 6882-6890, 2000.

23. Bonnet D and Dick JE. Human acute myeloid leukemia is organized as a hierarchy that originates from a primitive hematopoietic cell. Nat Med 3: 730-737, 1997.

24. Bosetti C, Filomeno M, Riso P, Polesel J, Levi F, Talamini R, Montella M, Negri E, Franceschi S, and La Vecchia C. Cruciferous vegetables and cancer risk in a network of case-control studies. Ann Oncol 23: 2198-2203, 2012.

25. Brown AF, Yousef GG, Jeffery EH, Klein BP, Wallig MA, Kushad MM, and Juvik JA. Glucosinolate profiles in broccoli: variation in levels and implications in breeding for cancer chemoprotection. J Am Soc Horticultural Sci 127: 807-813, 2002.

26. Brüsewitz G, Cameron BD, Chasseaud LF, Görler K, Hawkins DR, Koch H, and Mennicke WH. The metabolism of benzyl isothiocyanate and its cysteine conjugate. Biochem J 162: 99-107, 1977.

27. Busch A, Horn S, Muhlhausen A, Mummenhoff K, and Zachgo S. Corolla monosymmetry: evolution of a morphological novelty in the Brassicaceae family. Mol Biol Evol 29: 1241-1254, 2012.

28. Caamano J, Zhang SY, Rosvold EA, Bauer B, and KleinSzanto AJP. p53 Alterations in human squamous cell carcinomas and carcinoma cell lines. Am J Pathol 142: 1131-1139, 1993.

29. Calin GA and Croce CM. MicroRNA signatures in human cancers. Nat Rev Cancer 6: 857-866, 2006.

30. Castilla MA, Moreno-Bueno G, Romero-Perez L, Van De Vijver K, Biscuola M, Lopez-Garcia MA, Prat J, MatiasGuiu X, Cano A, Oliva E, and Palacios J. Micro-RNA signature of the epithelial-mesenchymal transition in endometrial carcinosarcoma. J Pathol 223: 72-80, 2011.

31. Chang CC, Hung CM, Yang YR, Lee MJ, and Hsu YC. Sulforaphane induced cell cycle arrest in the G2/M phase via the blockade of cyclin B1/CDC2 in human ovarian cancer cells. J Ovarian Res 6: 1757-2215, 2013.

32. Charron CS, Saxton AM, and Sams CE. Relationship of climate and genotype to seasonal variation in the glucosinolate-myrosinase system. I. Glucosinolate content in ten cultivars of Brassica oleracea grown in fall and spring seasons. J Sci Food Agric 85: 671-681, 2005.

33. Chaudhuri D, Orsulic S, and Ashok BT. Antiproliferative activity of sulforaphane in Akt-overexpressing ovarian cancer cells. Mol Cancer Ther 6: 334-345, 2007.

34. Chen L, Kasai T, Li Y, Sugii Y, Jin G, Okada M, Vaidyanath A, Mizutani A, Satoh A, Kudoh T, Hendrix MJ, Salomon DS, Fu L, and Seno M. A model of cancer stem cells derived from mouse induced pluripotent stem cells. PLoS One 7: 12, 2012.

35. Chen Y, Shertzer HG, Schneider SN, Nebert DW, and Dalton TP. Glutamate Cysteine ligase catalysis dependence on ATP and modifier subunit for regulation of tissue glutathione levels. J Biol Chem 280: 33766-33774, 2005.

36. Cheung KL and Kong AN. Molecular targets of dietary phenethyl isothiocyanate and sulforaphane for cancer chemoprevention. Aaps J 12: 87-97, 2010.
37. Chiao JW, Chung FL, Kancherla R, Ahmed T, Mittelman A, and Conaway CC. Sulforaphane and its metabolite mediate growth arrest and apoptosis in human prostate cancer cells. Int J Oncol 20: 631-636, 2002.

38. Cho S-D, Li G, Hu H, Jiang C, Kang K-S, Lee Y-S, Kim $\mathrm{S}-\mathrm{H}$, and Lu J. Involvement of c-Jun N-terminal kinase in G2/M arrest and caspase-mediated apoptosis induced by sulforaphane in DU145 prostate cancer cells. Nutr Cancer 52: 213-224, 2005.

39. Choi S, Lew KL, Xiao H, Herman-Antosiewicz A, Xiao D, Brown CK, and Singh SV. D, L-Sulforaphane-induced cell death in human prostate cancer cells is regulated by inhibitor of apoptosis family proteins and Apaf-1. Carcinogenesis 28: 151-162, 2007.

40. Ciska E, Martyniak-Przybyszewska B, and Kozlowska H. Content of glucosinolates in cruciferous vegetables grown at the same site for two years under different climatic conditions. J Agric Food Chem 48: 2862-2867, 2000.

41. Clarke JD, Dashwood RH, and Ho E. Multi-targeted prevention of cancer by sulforaphane. Cancer Lett 269: 291-304, 2008.

42. Clarke JD, Hsu A, Riedl K, Bella D, Schwartz SJ, Stevens JF, and Ho E. Bioavailability and inter-conversion of sulforaphane and erucin in human subjects consuming broccoli sprouts or broccoli supplement in a cross-over study design. Pharmacol Res 64: 456-463, 2011.

43. Clarke JD, Hsu A, Yu Z, Dashwood RH, and Ho E. Differential effects of sulforaphane on histone deacetylases, cell cycle arrest and apoptosis in normal prostate cells versus hyperplastic and cancerous prostate cells. Mol Nutr Food Res 55: 999-1009, 2011.

44. Clarke JD, Riedl K, Bella D, Schwartz SJ, Stevens JF, and Ho E. Comparison of isothiocyanate metabolite levels and histone deacetylase activity in human subjects consuming broccoli sprouts or broccoli supplement. J Agric Food Chem 59: 10955-10963, 2011.

45. Clossais-Besnard N and Larher F. Physiological role of glucosinolates in Brassica napus. Concentration and distribution pattern of glucosinolates among plant organs during a complete life cycle. J Sci Food Agric 56: 25-38, 1991.

46. Cohen JH, Kristal AR, and Stanford JL. Fruit and vegetable intakes and prostate cancer risk. $J$ Natl Cancer Inst 92: 61-68, 2000.

47. Conaway CC, Getahun SM, Liebes LL, Pusateri DJ, Topham DKW, Botero-Omary M, and Chung F-L. Disposition of glucosinolates and sulforaphane in humans after ingestion of steamed and fresh Broccoli. Nutr Cancer 38: 168-178, 2000.

48. Conaway CC, Krzeminski J, Amin S, and Chung F-L. Decomposition rates of isothiocyanate conjugates determine their activity as inhibitors of cytochrome P450 enzymes†. Chem Res Toxicol 14: 1170-1176, 2001.

49. Conaway CC, Wang CX, Pittman B, Yang YM, Schwartz JE, Tian D, McIntee EJ, Hecht SS, and Chung FL. Phenethyl isothiocyanate and sulforaphane and their $\mathrm{N}$-acetylcysteine conjugates inhibit malignant progression of lung adenomas induced by tobacco carcinogens in $\mathrm{A} / \mathrm{J}$ mice. Cancer Res 65: 8548-8557, 2005.

50. Constantinescu S, Hecht K, Sobotzki N, Erzinger MM, Bovet C, Shay JW, Wollscheid B, Sturla SJ, Marra G, and Beerenwinkel N. Transcriptomic Responses of Cancerous and Noncancerous Human Colon Cells to Sulforaphane and Selenium. Chem Res Toxicol 13: 13, 2014. 
51. Cornblatt BS, Ye L, Dinkova-Kostova AT, Erb M, Fahey JW, Singh NK, Chen MS, Stierer T, Garrett-Mayer E, Argani P, Davidson NE, Talalay P, Kensler TW, and Visvanathan K. Preclinical and clinical evaluation of sulforaphane for chemoprevention in the breast. Carcinogenesis 28: 1485-1490, 2007.

52. Cornelis MC, El-Sohemy A, and Campos H. GSTT1 genotype modifies the association between cruciferous vegetable intake and the risk of myocardial infarction. $A m$ J Clin Nutr 86: 752-758, 2007.

53. Cotton SC, Sharp L, Little J, and Brockton N. Glutathione S-Transferase Polymorphisms and Colorectal Cancer: a HuGE Review. Am J Epidemiol 151: 7-32, 2000.

54. Cramer JM and Jeffery EH. Sulforaphane Absorption and Excretion Following Ingestion of a Semi-Purified Broccoli Powder Rich in Glucoraphanin and Broccoli Sprouts in Healthy Men. Nutr Cancer 63: 196-201, 2011.

55. Cramer JM, Teran-Garcia M, and Jeffery EH. Enhancing sulforaphane absorption and excretion in healthy men through the combined consumption of fresh broccoli sprouts and a glucoraphanin-rich powder. Br J Nutr 13: 1-6, 2011.

56. Dashwood RH and Ho E. Dietary histone deacetylase inhibitors: from cells to mice to man. Semin Cancer Biol 17: 363-369, 2007.

57. Dashwood RH, Myzak MC, and Ho E. Dietary HDAC inhibitors: time to rethink weak ligands in cancer chemoprevention? Carcinogenesis 27: 344-349, 2006.

58. de Quiros HC, Magrath R, McCallum D, Kroymann J, Scnabelrauch D, Mitchell-Olds T, and Mithen R. $\alpha$-Keto acid elongation and glucosinolate biosynthesis in Arabidopsis thaliana. Theor Appl Genet 101: 429-437, 2000.

59. Dekant W and Vamvakas S. Glutathione-dependent bioactivation of xenobiotics. Xenobiotica 23: 873-887, 1993.

60. Ding Y, Paonessa JD, Randall KL, Argoti D, Chen L, Vouros P, and Zhang Y. Sulforaphane inhibits 4-aminobiphenyl-induced DNA damage in bladder cells and tissues. Carcinogenesis 31: 1999-2003, 2010.

61. Dinkova-Kostova AT, Fahey JW, Wade KL, Jenkins SN, Shapiro TA, Fuchs EJ, Kerns ML, and Talalay P. Induction of the phase 2 response in mouse and human skin by sulforaphane-containing broccoli sprout extracts. Cancer Epidemiol Biomarkers Prev 16: 847-851, 2007.

62. Dinkova-Kostova AT, Holtzclaw WD, Cole RN, Itoh K, Wakabayashi N, Katoh Y, Yamamoto M, and Talalay P. Direct evidence that sulfhydryl groups of Keap1 are the sensors regulating induction of phase 2 enzymes that protect against carcinogens and oxidants. Proc Natil Acad Sci U S A 99: 11908-11913, 2002.

63. Dontu G, Al-Hajj M, Abdallah WM, Clarke MF, and Wicha MS. Stem cells in normal breast development and breast cancer. Cell Prolif 1: 59-72, 2003.

64. Dosz EB and Jeffery EH. Commercially produced frozen broccoli lacks the ability to form sulforaphane. J Funct Foods 5: 987-990, 2013.

65. Doudican NA, Bowling B, and Orlow SJ. Enhancement of arsenic trioxide cytotoxicity by dietary isothiocyanates in human leukemic cells via a reactive oxygen speciesdependent mechanism. Leuk Res 34: 229-234, 2010.

66. Doudican NA, Wen SY, Mazumder A, and Orlow SJ. Sulforaphane synergistically enhances the cytotoxicity of arsenic trioxide in multiple myeloma cells via stressmediated pathways. Oncol Rep 28: 1851-1858, 2012.

67. Egner PA, Chen JG, Wang JB, Wu Y, Sun Y, Lu JH, Zhu J, Zhang YH, Chen YS, Friesen MD, Jacobson LP,
Munoz A, Ng D, Qian GS, Zhu YR, Chen TY, Botting NP, Zhang Q, Fahey JW, Talalay P, Groopman JD, and Kensler TW. Bioavailability of Sulforaphane from two broccoli sprout beverages: results of a short-term, crossover clinical trial in Qidong, China. Cancer Prev Res 4: 384-395, 2011.

68. Ellis L, Atadja PW, and Johnstone RW. Epigenetics in cancer: targeting chromatin modifications. Mol Cancer Ther 8: 1409-1420, 2009.

69. Etoh T, Kanai Y, Ushijima S, Nakagawa T, Nakanishi Y, Sasako M, Kitano S, and Hirohashi S. Increased DNA methyltransferase 1 (DNMT1) protein expression correlates significantly with poorer tumor differentiation and frequent DNA hypermethylation of multiple $\mathrm{CpG}$ islands in gastric cancers. Am J Pathol 164: 689-699, 2004.

70. Fahey J, Stephenson Katherine K, and Talalay P. Glucosinolates, Myrosinase, and Isothiocyanates: three Reasons for Eating Brassica Vegetables. In: Functional Foods for Disease Prevention I. Symposium sponsored by the division of Agricultural and Food Chemistry at the 213th National Meeting of the American Chemical Society, San Francisco, CA, April 13-17, 1997, 1998. pp. 16-22.

71. Fahey JW, Haristoy X, Dolan PM, Kensler TW, Scholtus I, Stephenson KK, Talalay P, and Lozniewski A. Sulforaphane inhibits extracellular, intracellular, and antibioticresistant strains of Helicobacter pylori and prevents benzo[a]pyrene-induced stomach tumors. Proc Natl Acad Sci U S A 99: 7610-7615, 2002.

72. Fahey JW, Wehage SL, Holtzclaw WD, Kensler TW, Egner PA, Shapiro TA, and Talalay P. Protection of Humans by Plant Glucosinolates: efficiency of Conversion of Glucosinolates to Isothiocyanates by the Gastrointestinal Microflora. Cancer Prev Res 5: 603-611, 2012.

73. Fahey JW, Zhang Y, and Talalay P. Broccoli sprouts: an exceptionally rich source of inducers of enzymes that protect against chemical carcinogens. Proc Natl Acad Sci U S A 94: 10367-10372, 1997.

74. Farnham M, Wilson P, Stephenson K, and Fahey J. Genetic and environmental effects on glucosinolate content and chemoprotective potency of broccoli. Plant Breeding 123: 60-65, 2004.

75. Feskanich D, Ziegler RG, Michaud DS, Giovannucci EL, Speizer FE, Willett WC, and Colditz GA. Prospective study of fruit and vegetable consumption and risk of lung cancer among men and women. J Natl Cancer Inst 92: 1812-1823, 2000.

76. Field B, Cardon G, Traka M, Botterman J, Vancanneyt G, and Mithen R. Glucosinolate and Amino Acid Biosynthesis in Arabidopsis. Plant Physiol 135: 828-839, 2004.

77. Fimognari C, Lenzi M, and Hrelia P. Interaction of the isothiocyanate sulforaphane with drug disposition and metabolism: pharmacological and toxicological implications. Curr Drug Metabol 9: 668-678, 2008.

78. Fimognari C, Lenzi M, Sciuscio D, Cantelli-Forti G, and Hrelia P. Cell-cycle specificity of sulforaphane-mediated apoptosis in Jurkat T-leukemia cells. In Vivo 21: 377-380, 2007.

79. Fimognari C, Lenzi M, Sciuscio D, Cantelli-Forti G, and Hrelia P. Combination of doxorubicin and sulforaphane for reversing doxorubicin-resistant phenotype in mouse fibroblasts with p53Ser220 mutation. Ann N Y Acad Sci: 62-69, 2007.

80. Fimognari C, Nusse M, Lenzi M, Sciuscio D, CantelliForti G, and Hrelia P. Sulforaphane increases the efficacy 
of doxorubicin in mouse fibroblasts characterized by p53 mutations. Mutat Res 601: 92-101, 2006.

81. Fowke JH, Chung FL, Jin F, Qi D, Cai Q, Conaway C, Cheng JR, Shu XO, Gao YT, and Zheng W. Urinary isothiocyanate levels, brassica, and human breast cancer. Cancer Res 63: 3980-3986, 2003.

82. Franzke A, Lysak MA, Al-Shehbaz IA, Koch MA, and Mummenhoff K. Cabbage family affairs: the evolutionary history of Brassicaceae. Trends Plant Sci 16: 108-116, 2011.

83. Fresno Vara JA, Casado E, de Castro J, Cejas P, BeldaIniesta C, and Gonzalez-Baron M. PI3K/Akt signalling pathway and cancer. Cancer Treat Rev 30: 193-204, 2004.

84. Gamet-Payrastre L, Li P, Lumeau S, Cassar G, Dupont M-A, Chevolleau S, Gasc N, Tulliez J, and Tercé F. Sulforaphane, a naturally occurring isothiocyanate, induces cell cycle arrest and apoptosis in HT29 human colon cancer cells. Cancer Res 60: 1426-1433, 2000.

85. Gasper AV, Al-janobi A, Smith JA, Bacon JR, Fortun P, Atherton C, Taylor MA, Hawkey CJ, Barrett DA, and Mithen RF. Glutathione S-transferase M1 polymorphism and metabolism of sulforaphane from standard and highglucosinolate broccoli. Am J Clin Nutr 82: 1283-1291, 2005.

86. Gasper AV, Traka M, Bacon JR, Smith JA, Taylor MA, Hawkey CJ, Barrett DA, and Mithen RF. Consuming broccoli does not induce genes associated with xenobiotic metabolism and cell cycle control in human gastric mucosa. J Nutr 137: 1718-1724, 2007.

87. Geisler S, Lønning PE, Aas T, Johnsen H, Fluge $\varnothing$, Haugen DF, Lillehaug JR, Akslen LA, and Børresen-Dale AL. Influence of TP53 gene alterations and c-erbB-2 expression on the response to treatment with doxorubicin in locally advanced breast cancer. Cancer Res 61: 25052512, 2001.

88. German DA and Al-Shehbaz IA. Nomenclatural novelties in miscellaneous Asian Brassicaceae (Cruciferae). Nord J Bot 28: 646-651, 2010.

89. Gibbs A, Schwartzman J, Deng V, and Alumkal J. Sulforaphane destabilizes the androgen receptor in prostate cancer cells by inactivating histone deacetylase 6. Proc Natl Acad Sci U S A 106: 16663-16668, 2009.

90. Gigolashvili T, Engqvist M, Yatusevich R, Müller C, and Flügge U-I. HAG2/MYB76 and HAG3/MYB29 exert a specific and coordinated control on the regulation of aliphatic glucosinolate biosynthesis in Arabidopsis thaliana. New Phytologist 177: 627-642, 2008.

91. Gigolashvili T, Yatusevich R, Berger B, Müller C, and Flügge U-I. The R2R3-MYB transcription factor HAG1/ MYB28 is a regulator of methionine-derived glucosinolate biosynthesis in Arabidopsis thaliana. Plant J 51: 247-261, 2007.

92. Gills JJ, Jeffery EH, Matusheski NV, Moon RC, Lantvit DD, and Pezzuto JM. Sulforaphane prevents mouse skin tumorigenesis during the stage of promotion. Cancer Lett 236: 72-79, 2006.

93. Giovannucci E, Rimm EB, Liu Y, Stampfer MJ, and Willett WC. A prospective study of cruciferous vegetables and prostate cancer. Cancer Epidemiol Biomarkers Prev 12: 1403-1409, 2003.

94. Graham S, Dayal H, Swanson M, Mittelman A, and Wilkinson G. Diet in the epidemiology of cancer of the colon and rectum. J Natl Cancer Inst 61: 709-714, 1978.

95. Grandhi BK, Thakkar A, Wang J, and Prabhu S. A novel combinatorial nanotechnology-based oral chemopreven- tive regimen demonstrates significant suppression of pancreatic cancer neoplastic lesions. Cancer Prev Res 6: 1015-1025, 2013.

96. Gross-Steinmeyer K, Stapleton PL, Tracy JH, Bammler TK, Strom SC, and Eaton DL. Sulforaphane-and phenethyl isothiocyanate-induced inhibition of aflatoxin B1-mediated genotoxicity in human hepatocytes: role of GSTM1 genotype and CYP3A4 gene expression. Toxicol Sci 116: 422-432, 2010.

97. Guengerich P. Metabolic activation of carcinogens. Pharmacol Ther 54: 17-61, 1992.

98. Hall C, McCallum D, Prescott A, and Mithen R. Biochemical genetics of glucosinolate modification in Arabidopsis and Brassica. Theor Appl Genet 102: 369-374, 2001.

99. Hansen BG, Kliebenstein DJ, and Halkier BA. Identification of a flavin-monooxygenase as the S-oxygenating enzyme in aliphatic glucosinolate biosynthesis in Arabidopsis. Plant J 50: 902-910, 2007.

100. Haston E, Richardson JE, Stevens PF, Chase MW, and Harris DJ. The Linear Angiosperm Phylogeny Group (LAPG) III: a linear sequence of the families in APG III. Botanical J Linnean Soc 161: 128-131, 2009.

101. Hayes JD and Strange RC. Glutathione S-Transferase Polymorphisms and Their Biological Consequences. Pharmacology 61: 154-166, 2000.

102. He H, Fingerling G, and Schnitzler WH. Glucosinolate contents and patterns in different organs of Chinese cabbages, Chinese kale (Brassica alboglabra bailey) and choy sum (Brassica campestris L. ssp chinensis var. utilis Tsen et Lee). J Appl Bot Angew Botanik 74: 21-25, 2000.

103. Heiss E and Gerhauser C. Time-dependent modulation of thioredoxin reductase activity might contribute to sulforaphane-mediated inhibition of NF-kappaB binding to DNA. Antioxid Redox Signal 7: 1601-1611, 2005.

104. Heiss E, Herhaus C, Klimo K, Bartsch H, and Gerhauser C. Nuclear factor kappa B is a molecular target for sulforaphane-mediated anti-inflammatory mechanisms. J Biol Chem 276: 32008-32015, 2001.

105. Herman-Antosiewicz A, Johnson DE, and Singh SV. Sulforaphane causes autophagy to inhibit release of cytochrome $\mathrm{C}$ and apoptosis in human prostate cancer cells. Cancer Res 66: 5828-5835, 2006.

106. This reference has been deleted.

107. Herman-Antosiewicz A, Xiao H, Lew KL, and Singh SV. Induction of p21 protein protects against sulforaphaneinduced mitotic arrest in $\mathrm{LNCaP}$ human prostate cancer cell line. Mol Cancer Ther 6: 1673-1681, 2007.

108. Herr I and Büchler MW. Dietary constituents of broccoli and other cruciferous vegetables: implications for prevention and therapy of cancer. Cancer Treat Rev 36: 377383, 2010.

109. Hirai MY, Sugiyama K, Sawada Y, Tohge T, Obayashi T, Suzuki A, Araki R, Sakurai N, Suzuki H, Aoki K, Goda H, Nishizawa OI, Shibata D, and Saito K. Omics-based identification of Arabidopsis Myb transcription factors regulating aliphatic glucosinolate biosynthesis. Proc Natl Acad Sci U S A 104: 6478-6483, 2007.

110. Hong F, Freeman ML, and Liebler DC. Identification of sensor cysteines in human Keap1 modified by the cancer chemopreventive agent sulforaphane. Chem Res Toxicol 18: 1917-1926, 2005.

111. Houghton CA, Fassett RG, and Coombes JS. Sulforaphane: translational research from laboratory bench to clinic. Nutr Rev 71: 709-726, 2013. 
112. Hsing AW, McLaughlin JK, Schuman LM, Bjelke E, Gridley G, Wacholder S, Chien HT, and Blot WJ. Diet, tobacco use, and fatal prostate cancer: results from the Lutheran Brotherhood Cohort Study. Cancer Res 50: 6836-6840, 1990.

113. Hsu A, Wong CP, Yu Z, Williams DE, Dashwood RH, and Ho E. Promoter de-methylation of cyclin D2 by sulforaphane in prostate cancer cells. Clin Epigenetics 3: 1868-7083, 2011.

114. Hu R, Hebbar V, Kim B-R, Chen C, Winnik B, Buckley B, Soteropoulos P, Tolias P, Hart RP, and Kong A-NT. In vivo pharmacokinetics and regulation of gene expression profiles by isothiocyanate sulforaphane in the rat. J Pharmacol Exp Ther 310: 263-271, 2004.

115. Hu R, Khor TO, Shen G, Jeong W-S, Hebbar V, Chen C, Xu C, Reddy B, Chada K, and Kong A-NT. Cancer chemoprevention of intestinal polyposis in ApcMin/ + mice by sulforaphane, a natural product derived from cruciferous vegetable. Carcinogenesis 27: 2038-2046, 2006.

116. Hussain A, Mohsin J, Prabhu SA, Begum S, Nusri Qel A, Harish G, Javed E, Khan MA, and Sharma C. Sulforaphane inhibits growth of human breast cancer cells and augments the therapeutic index of the chemotherapeutic drug, gemcitabine. Asian Pac J Cancer Prev 14: 58555860, 2013.

117. Itoh K, Wakabayashi N, Katoh Y, Ishii T, O’Connor T, and Yamamoto M. Keap1 regulates both cytoplasmicnuclear shuttling and degradation of Nrf2 in response to electrophiles. Genes Cells 8: 379-391, 2003.

118. Iwatsuki M, Mimori K, Yokobori T, Ishi H, Beppu T, Nakamori S, Baba H, and Mori M. Epithelial-mesenchymal transition in cancer development and its clinical significance. Cancer Sci 101: 293-299, 2010.

119. Jain MG, Hislop GT, Howe GR, and Ghadirian P. Plant foods, antioxidants, and prostate cancer risk: findings from case-control studies in Canada. Nutr Cancer 34: 173-184, 1999.

120. Jakubíková J, Sedlák J, Mithen R, and Bao Y. Role of $\mathrm{PI} 3 \mathrm{~K} / \mathrm{Akt}$ and MEK/ERK signaling pathways in sulforaphane-and erucin-induced phase II enzymes and MRP2 transcription, $\mathrm{G}_{2} / \mathrm{M}$ arrest and cell death in Caco- 2 cells. Biochem Pharmacol 69: 1543-1552, 2005.

121. Janobi AAA, Mithen RF, Gasper AV, Shaw PN, Middleton RJ, Ortori CA, and Barrett DA. Quantitative measurement of sulforaphane, iberin and their mercapturic acid pathway metabolites in human plasma and urine using liquid chromatography-tandem electrospray ionisation mass spectrometry. J Chromatogr B 844: 223234, 2006

122. Jeffery EH and Keck AS. Translating knowledge generated by epidemiological and in vitro studies into dietary cancer prevention. Mol Nutr Food Res 52: S7-S17, 2008.

123. Jeong J-K, Moon M-H, Seo J-S, Seol J-W, Lee Y-J, and Park S-Y. Sulforaphane blocks hypoxia-mediated resistance to TRAIL-induced tumor cell death. Mol Med Rep 4: 325-330, 2011.

124. Jeong W-S, Kim I-W, Hu R, and Kong A-NT. Modulation of AP-1 by natural chemopreventive compounds in human colon HT-29 cancer cell line. Pharm Res 21: 649-660, 2004.

125. Jeong WS, Kim IW, Hu R, and Kong AN. Modulatory properties of various natural chemopreventive agents on the activation of NF-kappaB signaling pathway. Pharm Res 21: 661-670, 2004.
126. Jiang H, Shang X, Wu H, Huang G, Wang Y, Al-Holou S, Gautam SC, and Chopp M. Combination treatment with resveratrol and sulforaphane induces apoptosis in human U251 glioma cells. Neurochem Res 35: 152-161, 2010.

127. Jones R, Frisina C, Winkler S, Imsic M, and Tomkins R. Cooking method significantly effects glucosinolate content and sulforaphane production in broccoli florets. Food Chem 123: 237-242, 2010.

128. Jones SB and Brooks JD. Modest induction of phase 2 enzyme activity in the F-344 rat prostate. BMC Cancer 6: 62, 2006.

129. Joseph MA, Moysich KB, Freudenheim JL, Shields PG, Bowman ED, Zhang Y, Marshall JR, and Ambrosone CB. Cruciferous vegetables, genetic polymorphisms in glutathione S-transferases M1 and T1, and prostate cancer risk. Nutr Cancer 50: 206-213, 2004.

130. Joshipura KJ, Ascherio A, Manson JE, Stampfer MJ, Rimm EB, Speizer FE, Hennekens CH, Spiegelman D, and Willett WC. Fruit and vegetable intake in relation to risk of ischemic stroke. Jama 282: 1233-1239, 1999.

131. Juge N, Mithen RF, and Traka M. Molecular basis for chemoprevention by sulforaphane: a comprehensive review. Cell Mol Life Sci 64: 1105-1127, 2007.

132. Kallifatidis G, Labsch S, Rausch V, Mattern J, Gladkich J, Moldenhauer G, Buchler MW, Salnikov AV, and Herr I. Sulforaphane increases drug-mediated cytotoxicity toward cancer stem-like cells of pancreas and prostate. Mol Ther 19: 188-195, 2011.

133. Kallifatidis G, Rausch V, Baumann B, Apel A, Beckermann BM, Groth A, Mattern J, Li Z, Kolb A, Moldenhauer G, Altevogt P, Wirth T, Werner J, Schemmer P, Büchler MW, Salnikov AV, and Herr I. Sulforaphane targets pancreatic tumour-initiating cells by NF- $\kappa \mathrm{B}$ induced antiapoptotic signalling. Gut 58: 949-963, 2009.

134. Kalpana Deepa Priya D, Gayathri R, Gunassekaran GR, Murugan S, and Sakthisekaran D. Apoptotic role of natural isothiocyanate from broccoli (Brassica oleracea italica) in experimental chemical lung carcinogenesis. Pharm Biol 51: 621-628, 2013.

135. Kaminski BM, Weigert A, Brune B, Schumacher M, Wenzel U, Steinhilber D, Stein J, and Ulrich S. Sulforaphane potentiates oxaliplatin-induced cell growth inhibition in colorectal cancer cells via induction of different modes of cell death. Cancer Chemother Pharmacol 67: 1167-1178, 2011.

136. Kanematsu S, Uehara N, Miki H, Yoshizawa K, Kawanaka A, Yuri T, and Tsubura A. Autophagy inhibition enhances sulforaphane-induced apoptosis in human breast cancer cells. Anticancer Res 30: 3381-3390, 2010.

137. Karin M. NF-kappaB and cancer: mechanisms and targets. Mol Carcinog 45: 355-361, 2006.

138. Kensler TW. Chemoprevention by inducers of carcinogen detoxication enzymes. Environ Health Perspect 105: 965, 1997.

139. Kensler TW, Chen JG, Egner PA, Fahey JW, Jacobson LP, Stephenson KK, Ye L, Coady JL, Wang JB, Wu Y, Sun Y, Zhang QN, Zhang BC, Zhu YR, Qian GS, Carmella SG, Hecht SS, Benning L, Gange SJ, Groopman JD, and Talalay P. Effects of glucosinolate-rich broccoli sprouts on urinary levels of aflatoxin-DNA adducts and phenanthrene tetraols in a randomized clinical trial in He Zuo township, Qidong, People's Republic of China. Cancer Epidemiol Biomarkers Prev 14: 2605-2613, 2005. 
140. Kensler TW, Ng D, Carmella SG, Chen M, Jacobson LP, Muñoz A, Egner PA, Chen JG, Qian GS, and Chen TY. Modulation of the metabolism of airborne pollutants by glucoraphanin-rich and sulforaphane-rich broccoli sprout beverages in Qidong, China. Carcinogenesis 33: 101-107, 2012.

141. Key TJ, Allen N, Appleby P, Overvad K, Tjonneland A, Miller A, Boeing H, Karalis D, Psaltopoulou T, Berrino F, Palli D, Panico S, Tumino R, Vineis $\mathrm{P}$, BuenoDe-Mesquita HB, Kiemeney L, Peeters PH, Martinez C, Dorronsoro M, Gonzalez CA, Chirlaque MD, Quiros JR, Ardanaz E, Berglund G, Egevad L, Hallmans G, Stattin P, Bingham S, Day N, Gann P, Kaaks R, Ferrari P, and Riboli E. Fruits and vegetables and prostate cancer: no association among 1104 cases in a prospective study of 130544 men in the European Prospective Investigation into Cancer and Nutrition (EPIC). Int J Cancer 109: 119124, 2004.

142. Khor TO, Hu R, Shen G, Jeong WS, Hebbar V, Chen C, Xu C, Nair S, Reddy B, and Chada K. Pharmacogenomics of cancer chemopreventive isothiocyanate compound sulforaphane in the intestinal polyps of ApcMin/ + mice. Biopharm Drug Dispos 27: 407-420, 2006.

143. Kim H, Kim EH, Eom YW, Kim WH, Kwon TK, Lee SJ, and Choi KS. Sulforaphane sensitizes tumor necrosis factor-related apoptosis-inducing ligand (TRAIL)-resistant hepatoma cells to TRAIL-induced apoptosis through reactive oxygen species-mediated up-regulation of DR5. Cancer Res 66: 1740-1750, 2006.

144. Kim S-J and Ishii G. Glucosinolate profiles in the seeds, leaves and roots of rocket salad (Eruca sativa Mill.) and anti-oxidative activities of intact plant powder and purified 4-methoxyglucobrassicin. Soil Sci Plant Nutr 52: 394-400, 2006.

145. Kim SJ, Kang SY, Shin HH, and Choi HS. Sulforaphane inhibits osteoclastogenesis by inhibiting nuclear factorkappaB. Mol Cells 20: 364-370, 2005.

146. Kirsh VA, Peters U, Mayne ST, Subar AF, Chatterjee N, Johnson CC, and Hayes RB. Prospective study of fruit and vegetable intake and risk of prostate cancer. J Natl Cancer Inst 99: 1200-1209, 2007.

147. Kobayashi H, Boelte KC, and Lin PC. Endothelial cell adhesion molecules and cancer progression. Curr Med Chem 14: 377-386, 2007.

148. Kobayashi M and Yamamoto M. Molecular mechanisms activating the Nrf2-Keap1 pathway of antioxidant gene regulation. Antioxid Redox Signal 7: 385-394, 2005.

149. Kobayashi T, Nakamura E, Shimizu Y, Terada N, Maeno A, Kobori G, Kamba T, Kamoto T, Ogawa O, and Inoue T. Restoration of cyclin D2 has an inhibitory potential on the proliferation of LNCaP cells. Biochem Biophys Res Commun 387: 196-201, 2009.

150. Koch MA, Dobeš C, Kiefer C, Schmickl R, Klimeš L, and Lysak MA. Supernetwork Identifies Multiple Events of Plastid trnF(GAA) Pseudogene Evolution in the Brassicaceae. Mol Biol Evol 24: 63-73, 2007.

151. Kolm RH, Danielson UH, Zhang Y, Talalay P, and Mannervik B. Isothiocyanates as substrates for human glutathione transferases: structure-activity studies. Biochem J 311: 453-459, 1995.

152. Kolonel LN, Hankin JH, Whittemore AS, Wu AH, Gallagher RP, Wilkens LR, John EM, Howe GR, Dreon DM, West DW, and Paffenbarger RS, Jr. Vegetables, fruits, legumes and prostate cancer: a multiethnic case-control study. Cancer Epidemiol Biomarkers Prev 9: 795-804, 2000.

153. Koo JE, Park Z-Y, Kim ND, and Lee JY. Sulforaphane inhibits the engagement of LPS with TLR4/MD2 complex by preferential binding to Cys133 in MD2. Biochem Biophys Res Commun 434: 600-605, 2013.

154. This reference has been deleted.

155. Korkaya $\mathrm{H}$ and Wicha MS. HER-2, notch, and breast cancer stem cells: targeting an axis of evil. Clin Cancer Res 15: 1845-1847, 2009.

156. Kristal AR and Lampe JW. Brassica vegetables and prostate cancer risk: a review of the epidemiological evidence. Nutr Cancer 42: 1-9, 2002.

157. Kushad MM, Brown AF, Kurilich AC, Juvik JA, Klein BP, Wallig MA, and Jeffery EH. Variation of Glucosinolates in Vegetable Crops of Brassica oleracea. J Agric Food Chem 47: 1541-1548, 1999.

158. La Marca M, Beffy P, Della Croce C, Gervasi PG, Iori R, Puccinelli E, and Longo V. Structural influence of isothiocyanates on expression of cytochrome P450, phase II enzymes, and activation of Nrf2 in primary rat hepatocytes. Food Chem Toxicol 50: 2822-2830, 2012.

159. Lam TK, Gallicchio L, Lindsley K, Shiels M, Hammond E, Tao XG, Chen L, Robinson KA, Caulfield LE, Herman JG, Guallar E, and Alberg AJ. Cruciferous vegetable consumption and lung cancer risk: a systematic review. Cancer Epidemiol Biomarkers Prev 18: 184-195, 2009.

160. Larsson SC, Hakansson N, Naslund I, Bergkvist L, and Wolk A. Fruit and vegetable consumption in relation to pancreatic cancer risk: a prospective study. Cancer Epidemiol Biomarkers Prev 15: 301-305, 2006.

161. Lee SA, Fowke JH, Lu W, Ye C, Zheng Y, Cai Q, Gu K, Gao YT, Shu XO, and Zheng W. Cruciferous vegetables, the GSTP1 Ile105Val genetic polymorphism, and breast cancer risk. Am J Clin Nutr 87: 753-760, 2008.

162. Lee YR, Noh EM, Han JH, Kim JM, Hwang BM, Kim BS, Lee SH, Jung SH, Youn HJ, Chung EY, and Kim JS. Sulforaphane controls TPA-induced MMP-9 expression through the NF-kappaB signaling pathway, but not AP-1, in MCF-7 breast cancer cells. BMB Rep 46: 201-206, 2013.

163. Levi MS, Borne RF, and Williamson JS. A Review of Cancer Chemopreventive Agents. Curr Med Chem 8: 1349-1362, 2001.

164. Li G and Quiros CF. Sequence-related amplified polymorphism (SRAP), a new marker system based on a simple PCR reaction: its application to mapping and gene tagging in Brassica. Theor Appl Genet 103: 455-461, 2001.

165. Li Q, Eades G, Yao Y, Zhang Y, and Zhou Q. Characterization of a Stem-like Subpopulation in Basal-like Ductal Carcinoma in Situ (DCIS) Lesions. J Biol Chem 289: 1303-1312, 2014.

166. Li Q, Yao Y, Eades G, Liu Z, Zhang Y, and Zhou Q. Downregulation of miR-140 promotes cancer stem cell formation in basal-like early stage breast cancer. Oncogene 10: 226, 2013.

167. Li SH, Fu J, Watkins DN, Srivastava RK, and Shankar S. Sulforaphane regulates self-renewal of pancreatic cancer stem cells through the modulation of Sonic hedgehog-GLI pathway. Mol Cell Biochem 373: 217-227, 2013.

168. Li Y and Zhang T. Targeting cancer stem cells with sulforaphane, a dietary component from broccoli and broccoli sprouts. Future Oncol 9: 1097-1103, 2013.

169. Li Y, Zhang T, Korkaya H, Liu S, Lee HF, Newman B, Yu Y, Clouthier SG, Schwartz SJ, Wicha MS, and Sun D. 
Sulforaphane, a dietary component of broccoli/broccoli sprouts, inhibits breast cancer stem cells. Clin Cancer Res 16: 2580-2590, 2010.

170. Lin HJ, Probst-Hensch NM, Louie AD, Kau IH, Witte JS, Ingles SA, Frankl HD, Lee ER, and Haile RW. Glutathione transferase null genotype, broccoli, and lower prevalence of colorectal adenomas. Cancer Epidemiol Biomarkers Prev 7: 647-652, 1998.

171. Lin LC, Yeh CT, Kuo CC, Lee CM, Yen GC, Wang LS, $\mathrm{Wu} \mathrm{CH}$, Yang WC, and Wu AT. Sulforaphane potentiates the efficacy of imatinib against chronic leukemia cancer stem cells through enhanced abrogation of Wnt/ beta-catenin function. J Agric Food Chem 60: 70317039, 2012.

172. Lin RK, Wu CY, Chang JW, Juan LJ, Hsu HS, Chen CY, Lu YY, Tang YA, Yang YC, Yang PC, and Wang YC. Dysregulation of p53/Sp1 control leads to DNA methyltransferase-1 overexpression in lung cancer. Cancer Res 70: 5807-5817, 2010.

173. Lin Y-S, Hung S-C, Wei Y-H, and Tarng D-C. GST M1 Polymorphism Associates with DNA Oxidative Damage and Mortality among Hemodialysis Patients. J Am Soc Nephrol 20: 405-415, 2009.

174. Liu B, Mao Q, Cao M, and Xie L. Cruciferous vegetables intake and risk of prostate cancer: a meta-analysis. Int $J$ Urol 19: 134-141, 2012.

175. Liu X and Lv K. Cruciferous vegetables intake is inversely associated with risk of breast cancer: a metaanalysis. Breast 22: 309-313, 2013.

176. Lock EA and Reed CJ. Xenobiotic Metabolizing Enzymes of the Kidney. Toxicol Pathol 26: 18-25, 1998.

177. Lorico A and Rappa G. Phenotypic heterogeneity of breast cancer stem cells. J Oncol 135039: 17, 2011.

178. Lyons A and Jones J. Cell adhesion molecules, the extracellular matrix and oral squamous carcinoma. Int J Oral Maxillofac Surg 36: 671-679, 2007.

179. MacLeod AK, McMahon M, Plummer SM, Higgins LG, Penning TM, Igarashi K, and Hayes JD. Characterization of the cancer chemopreventive NRF2-dependent gene battery in human keratinocytes: demonstration that the KEAP1-NRF2 pathway, and not the BACH1-NRF2 pathway, controls cytoprotection against electrophiles as well as redox-cycling compounds. Carcinogenesis 30: 1571-1580, 2009.

180. Magallon S, Crane PR, and Herendeen PS. Phylogenetic pattern, diversity, and diversification of eudicots. Ann Missouri Bot Gard 86: 297-372, 1999.

181. Mahéo K, Morel F, Langouët S, Kramer H, Le Ferrec E, Ketterer B, and Guillouzo A. Inhibition of cytochromes P450 and induction of glutathione S-transferases by sulforaphane in primary human and rat hepatocytes. Cancer Res 57: 3649-3652, 1997.

182. Matsui TA, Sowa Y, Yoshida T, Murata H, Horinaka M, Wakada M, Nakanishi R, Sakabe T, Kubo T, and Sakai T. Sulforaphane enhances TRAIL-induced apoptosis through the induction of DR5 expression in human osteosarcoma cells. Carcinogenesis 27: 1768-1777, 2006.

183. Matusheski NV and Jeffery EH. Comparison of the bioactivity of two glucoraphanin hydrolysis products found in broccoli, sulforaphane and sulforaphane nitrile. J Agric Food Chem 49: 5743-5749, 2001.

184. McCullough ML, Robertson AS, Chao A, Jacobs EJ, Stampfer MJ, Jacobs DR, Diver WR, Calle EE, and Thun MJ. A prospective study of whole grains, fruits, vegeta- bles and colon cancer risk. Cancer Causes Control 14: 959-970, 2003.

185. Meeran SM, Patel SN, Li Y, Shukla S, and Tollefsbol TO. Bioactive dietary supplements reactivate ER expression in ER-negative breast cancer cells by active chromatin modifications. PLoS One 7: 25, 2012.

186. Meeran SM, Patel SN, and Tollefsbol TO. Sulforaphane causes epigenetic repression of hTERT expression in human breast cancer cell lines. PLoS One 5: 0011457, 2010.

187. Michels KB, Edward G, Joshipura KJ, Rosner BA, Stampfer MJ, Fuchs CS, Colditz GA, Speizer FE, and Willett WC. Prospective study of fruit and vegetable consumption and incidence of colon and rectal cancers. J Natl Cancer Inst 92: 1740-1752, 2000.

188. Miller AB, Altenburg HP, Bueno-de-Mesquita B, Boshuizen HC, Agudo A, Berrino F, Gram IT, Janson L, Linseisen J, Overvad K, Rasmuson T, Vineis P, Lukanova A, Allen N, Amiano P, Barricarte A, Berglund G, Boeing H, Clavel-Chapelon F, Day NE, Hallmans G, Lund E, Martinez C, Navarro C, Palli D, Panico S, Peeters PH, Quiros JR, Tjonneland A, Tumino R, Trichopoulou A, Trichopoulos D, Slimani N, and Riboli E. Fruits and vegetables and lung cancer: findings from the European Prospective Investigation into Cancer and Nutrition. Int $J$ Cancer 108: 269-276, 2004.

189. Mirmiran P, Noori N, Zavareh MB, and Azizi F. Fruit and vegetable consumption and risk factors for cardiovascular disease. Metab Clin Exp 58: 460-468, 2009.

190. Mithen R, Bennett R, and Marquez J. Glucosinolate biochemical diversity and innovation in the Brassicales. Phytochemistry 71: 2074-2086, 2010.

191. Mithen R and Campos H. Genetic variation of aliphatic glucosinolates in Arabidopsis thaliana and prospects for map based gene cloning. Entomol Exp Appl 80: 202-205, 1996.

192. Mithen R, Raybould AF, and Giamoustaris A. Divergent selection for secondary metabolites between wild populations of Brassica oleracea and its implications for plantherbivore interactions. Heredity 75: 472, 1995.

193. Mizuno S, Chijiwa T, Okamura T, Akashi K, Fukumaki Y, Niho Y, and Sasaki H. Expression of DNA methyltransferases DNMT1, 3A, and 3B in normal hematopoiesis and in acute and chronic myelogenous leukemia. Blood 97: 1172-1179, 2001

194. Moon D-O, Kim M-O, Kang S-H, Choi YH, and Kim GY. Sulforaphane suppresses TNF- $\alpha$-mediated activation of $\mathrm{NF}-\kappa \mathrm{B}$ and induces apoptosis through activation of reactive oxygen species-dependent caspase-3. Cancer Lett 274: 132-142, 2009.

195. Morey Kinney SR, Smiraglia DJ, James SR, Moser MT, Foster BA, and Karpf AR. Stage-specific alterations of DNA methyltransferase expression, DNA hypermethylation, and DNA hypomethylation during prostate cancer progression in the transgenic adenocarcinoma of mouse prostate model. Mol Cancer Res 6: 1365-1374, 2008.

196. Mummaneni $\mathrm{P}$ and Shord SS. Epigenetics and oncology. Pharmacotherapy 34: 495-505, 2014.

197. Munday R and Munday CM. Induction of phase II detoxification enzymes in rats by plant-derived isothiocyanates: comparison of allyl isothiocyanate with sulforaphane and related compounds. J Agric Food Chem 52: 1867-1871, 2004.

198. Myzak MC, Dashwood WM, Orner GA, Ho E, and Dashwood RH. Sulforaphane inhibits histone deacetylase 
in vivo and suppresses tumorigenesis in Apc-minus mice. Faseb J 20: 506-508, 2006.

199. Myzak MC, Hardin K, Wang R, Dashwood RH, and Ho E. Sulforaphane inhibits histone deacetylase activity in $\mathrm{BPH}-$ 1, LnCaP and PC-3 prostate epithelial cells. Carcinogenesis 27: 811-819, 2006.

200. Myzak MC, Karplus PA, Chung FL, and Dashwood RH. A novel mechanism of chemoprotection by sulforaphane: inhibition of histone deacetylase. Cancer Res 64: 57675774, 2004.

201. Myzak MC, Tong P, Dashwood WM, Dashwood RH, and Ho E. Sulforaphane retards the growth of human PC-3 xenografts and inhibits HDAC activity in human subjects. Exp Biol Med 232: 227-234, 2007.

202. Nair S, Hebbar V, Shen G, Gopalakrishnan A, Khor TO, Yu $\mathrm{S}, \mathrm{Xu} \mathrm{C}$, and Kong AN. Synergistic effects of a combination of dietary factors sulforaphane and (-) epigallocatechin3-gallate in HT-29 AP-1 human colon carcinoma cells. Pharm Res 25: 387-399, 2008.

203. Nakashima H, Nakamura M, Yamaguchi H, Yamanaka N, Akiyoshi T, Koga K, Yamaguchi K, Tsuneyoshi M, Tanaka M, and Katano M. Nuclear factor-kappaB contributes to hedgehog signaling pathway activation through sonic hedgehog induction in pancreatic cancer. Cancer Res 66: 7041-7049, 2006.

204. Naumann P, Fortunato F, Zentgraf H, Buchler MW, Herr $\mathrm{I}$, and Werner J. Autophagy and cell death signaling following dietary sulforaphane act independently of each other and require oxidative stress in pancreatic cancer. Int J Oncol 39: 101-109, 2011.

205. Neuhouser ML, Patterson RE, Thornquist MD, Omenn GS, King IB, and Goodman GE. Fruits and vegetables are associated with lower lung cancer risk only in the placebo arm of the beta-carotene and retinol efficacy trial (CARET). Cancer Epidemiol Biomarkers Prev 12: 350-358, 2003.

206. Nguyen T, Nioi P, and Pickett CB. The Nrf2-antioxidant response element signaling pathway and its activation by oxidative stress. J Biol Chem 284: 13291-13295, 2009.

207. Nishikawa T, Tsuno NH, Okaji Y, Shuno Y, Sasaki K, Hongo K, Sunami E, Kitayama J, Takahashi K, and Nagawa $\mathrm{H}$. Inhibition of autophagy potentiates sulforaphaneinduced apoptosis in human colon cancer cells. Ann Surg Oncol 17: 592-602, 2010.

208. Nothlings U, Wilkens LR, Murphy SP, Hankin JH, Henderson BE, and Kolonel LN. Vegetable intake and pancreatic cancer risk: the multiethnic cohort study. Am J Epidemiol 165: 138-147, 2007.

209. O'Brien CA, Pollett A, Gallinger S, and Dick JE. A human colon cancer cell capable of initiating tumour growth in immunodeficient mice. Nature 445: 106-110, 2007.

210. Padilla G, Cartea ME, Velasco P, de Haro A, and Ordás A. Variation of glucosinolates in vegetable crops of Brassica rapa. Phytochemistry 68: 536-545, 2007.

211. Pappa G, Bartsch H, and Gerhauser C. Biphasic modulation of cell proliferation by sulforaphane at physiologically relevant exposure times in a human colon cancer cell line. Mol Nutr Food Res 51: 977-984, 2007.

212. Pappa G, Lichtenberg M, Iori R, Barillari J, Bartsch H, and Gerhäuser C. Comparison of growth inhibition profiles and mechanisms of apoptosis induction in human colon cancer cell lines by isothiocyanates and indoles from Brassicaceae. Mutat Res 599: 76-87, 2006.

213. Pappa G, Strathmann J, Lowinger M, Bartsch H, and Gerhauser C. Quantitative combination effects between sulforaphane and 3,3'-diindolylmethane on proliferation of human colon cancer cells in vitro. Carcinogenesis 28: 1471-1477, 2007.

214. Park HS, Han MH, Kim G-Y, Moon S-K, Kim W-J, Hwang HJ, Park KY, and Choi YH. Sulforaphane induces reactive oxygen species-mediated mitotic arrest and subsequent apoptosis in human bladder cancer 5637 cells. Food Chem Toxicol 64: 157-165, 2014.

215. Park SY, Kim GY, Bae S-J, Yoo YH, and Choi YH. Induction of apoptosis by isothiocyanate sulforaphane in human cervical carcinoma HeLa and hepatocarcinoma HepG2 cells through activation of caspase-3. Oncol Rep 18: 181-187, 2007.

216. Parnaud G, Li P, Cassar G, Rouimi P, Tulliez J, Combaret L, and Gamet-Payrastre L. Mechanism of sulforaphaneinduced cell cycle arrest and apoptosis in human colon cancer cells. Nutr Cancer 48: 198-206, 2004.

217. Pereira FMV, Rosa E, Fahey JW, Stephenson KK, Carvalho R, and Aires A. Influence of temperature and ontogeny on the levels of glucosinolates in broccoli (Brassica oleracea var. italica) sprouts and their effect on the induction of mammalian phase 2 enzymes. J Agric Food Chem 50: 6239-6244, 2002.

218. Petri N, Tannergren C, Holst B, Mellon FA, Bao Y, Plumb GW, Bacon J, O'Leary KA, Kroon PA, Knutson L, Forsell P, Eriksson T, Lennernas H, and Williamson G. Absorption/Metabolism of sulforaphane and quercetin, and regulation of phase II enzymes, in human jejunum in vivo. Drug Metab Dispos 31: 805-813, 2003.

219. Pledgie-Tracy A, Sobolewski MD, and Davidson NE. Sulforaphane induces cell type-specific apoptosis in human breast cancer cell lines. Mol Cancer Ther 6: 10131021, 2007.

220. Portela A and Esteller M. Epigenetic modifications and human disease. Nat Biotechnol 28: 1057-1068, 2010.

221. Pradhan SJ, Mishra R, Sharma P, and Kundu GC. Quercetin and sulforaphane in combination suppress the progression of melanoma through the down-regulation of matrix metalloproteinase-9. Exp Ther Med 1: 915-920, 2010.

222. Qiu D, Gao M, Li G, and Quiros C. Comparative sequence analysis for Brassica oleracea with similar sequences in B. rapa and Arabidopsis thaliana. Plant Cell Rep 28: 649661, 2009.

223. Rajendran P, Delage B, Dashwood WM, Yu TW, Wuth B, Williams DE, Ho E, and Dashwood RH. Histone deacetylase turnover and recovery in sulforaphane-treated colon cancer cells: competing actions of 14-3-3 and Pin1 in HDAC3/SMRT corepressor complex dissociation/ reassembly. Mol Cancer 10: 1476-4598, 2011.

224. Rajendran P, Kidane AI, Yu TW, Dashwood WM, Bisson WH, Lohr CV, Ho E, Williams DE, and Dashwood RH. HDAC turnover, CtIP acetylation and dysregulated DNA damage signaling in colon cancer cells treated with sulforaphane and related dietary isothiocyanates. Epigenetics 8: 612-623, 2013.

225. Ramirez MC and Singletary K. Regulation of estrogen receptor alpha expression in human breast cancer cells by sulforaphane. J Nutr Biochem 20: 195-201, 2009.

226. Rask L, Andreasson E, Ekbom B, Eriksson S, Pontoppidan B, and Meijer J. Myrosinase: gene family evolution and herbivore defense in Brassicaceae. Plant Mol Biol 42: 93-113, 2000.

227. Rausch V, Liu L, Kallifatidis G, Baumann B, Mattern J, Gladkich J, Wirth T, Schemmer P, Buchler MW, Zoller 
M, Salnikov AV, and Herr I. Synergistic activity of sorafenib and sulforaphane abolishes pancreatic cancer stem cell characteristics. Cancer Res 70: 5004-5013, 2010.

228. Rebbeck TR. Molecular epidemiology of the human glutathione S-transferase genotypes GSTM1 and GSTT1 in cancer susceptibility. Cancer Epidemiol Biomarkers Prev 6: 733-743, 1997.

229. Reed JC. Apoptosis-targeted therapies for cancer. Cancer cell 3: 17-22, 2003.

230. Reya T, Morrison SJ, Clarke MF, and Weissman IL. Stem cells, cancer, and cancer stem cells. Nature 414: 105-111, 2001.

231. Riedl MA, Saxon A, and Diaz-Sanchez D. Oral sulforaphane increases Phase II antioxidant enzymes in the human upper airway. Clin Immunol 130: 244-251, 2009.

232. Ritz SA, Wan J, and Diaz-Sanchez D. Sulforaphanestimulated phase II enzyme induction inhibits cytokine production by airway epithelial cells stimulated with diesel extract. Am J Physiol Lung Cell Mol Physiol 292: 11, 2007.

233. Rodova M, Fu J, Watkins DN, Srivastava RK, and Shankar S. Sonic hedgehog signaling inhibition provides opportunities for targeted therapy by sulforaphane in regulating pancreatic cancer stem cell self-renewal. PLoS One 7: 28, 2012.

234. Rodríguez-Hernández MC, Medina S, Gil-Izquierdo A, Martínez-Ballesta MC, and Moreno DA. Broccoli isothiocyanate content and in vitro availability according to variety and origin. Macedonian J Chem Chem Eng 32, 2013.

235. Rodriquez M, Aquino M, Bruno I, De Martino G, Taddei M, and Gomez-Paloma L. Chemistry and biology of chromatin remodeling agents: state of art and future perspectives of HDAC inhibitors. Curr Med Chem 13: 11191139, 2006.

236. Rosa EA and Rodrigues AS. Total and individual glucosinolate content in 11 broccoli cultivars grown in early and late seasons. Hortscience 36: 56-59, 2001.

237. Roy SK, Srivastava RK, and Shankar S. Inhibition of PI3K/AKT and MAPK/ERK pathways causes activation of FOXO transcription factor, leading to cell cycle arrest and apoptosis in pancreatic cancer. J Mol Signal 5: 17502187, 2010.

238. Rudolf E, Andělová H, and Červinka M. Activation of several concurrent proapoptic pathways by sulforaphane in human colon cancer cells SW620. Food Chem Toxicol 47: 2366-2373, 2009.

239. Rungapamestry V, Duncan AJ, Fuller Z, and Ratcliffe B. Effect of cooking brassica vegetables on the subsequent hydrolysis and metabolic fate of glucosinolates. Proc Nutr Soc 66: 69-81, 2007.

240. Saha S, Hollands W, Teucher B, Needs PW, Narbad A, Ortori CA, Barrett DA, Rossiter JT, Mithen RF, and Kroon PA. Isothiocyanate concentrations and interconversion of sulforaphane to erucin in human subjects after consumption of commercial frozen broccoli compared to fresh broccoli. Mol Nutr Food Res 56: 1906-1916, 2012.

241. Salvi A, Sabelli C, Moncini S, Venturin M, Arici B, Riva P, Portolani N, Giulini SM, De Petro G, and Barlati S. MicroRNA-23b mediates urokinase and c-met downmodulation and a decreased migration of human hepatocellular carcinoma cells. Febs J 276: 2966-2982, 2009.

242. Sarikamis G, Marquez J, Maccormack R, Bennett R, Roberts J, and Mithen R. High glucosinolate broccoli: a delivery system for sulforaphane. Mol Breeding 18: 219228, 2006.
243. Schonhof I, Krumbein A, and Brückner B. Genotypic effects on glucosinolates and sensory properties of broccoli and cauliflower. Food/Nahrung 48: 25-33, 2004.

244. Schuurman AG, Goldbohm RA, Dorant E, and van den Brandt PA. Vegetable and fruit consumption and prostate cancer risk: a cohort study in The Netherlands. Cancer Epidemiol Biomarkers Prev 7: 673-680, 1998.

245. Seow A, Shi CY, Chung FL, Jiao D, Hankin JH, Lee HP, Coetzee GA, and $\mathrm{Yu}$ MC. Urinary total isothiocyanate (ITC) in a population-based sample of middle-aged and older Chinese in Singapore: relationship with dietary total ITC and glutathione S-transferase M1/T1/P1 genotypes. Cancer Epidemiol Biomarkers Prev 7: 775-781, 1998.

246. Shan Y, Lin N, Yang X, Tan J, Zhao R, Dong S, and Wang S. Sulphoraphane inhibited the expressions of intercellular adhesion molecule-1 and vascular cell adhesion molecule-1 through MyD88-dependent toll-like receptor-4 pathway in cultured endothelial cells. Nutr Metab Cardiovasc Dis 22: 215-222, 2012.

247. Shan Y, Wang X, Wang W, He C, and Bao Y. p38 MAPK plays a distinct role in sulforaphane-induced up-regulation of ARE-dependent enzymes and down-regulation of COX-2 in human bladder cancer cells. Oncol Rep 23: 1133-1138, 2010.

248. Shan Y, Zhang L, Bao Y, Li B, He C, Gao M, Feng X, Xu W, Zhang X, and Wang S. Epithelial-mesenchymal transition, a novel target of sulforaphane via COX-2/MMP2, 9/ Snail, ZEB1 and miR-200c/ZEB1 pathways in human bladder cancer cells. J Nutr Biochem 24: 1062-1069, 2013.

249. This reference has been deleted.

250. Shapiro TA, Fahey JW, Dinkova-Kostova AT, Holtzclaw WD, Stephenson KK, Wade KL, Ye L, and Talalay P. Safety, Tolerance, and Metabolism of Broccoli Sprout Glucosinolates and Isothiocyanates: a Clinical Phase I Study. Nutr Cancer 55: 53-62, 2006.

251. Shapiro TA, Fahey JW, Wade KL, Stephenson KK, and Talalay P. Human metabolism and excretion of cancer chemoprotective glucosinolates and isothiocyanates of cruciferous vegetables. Cancer Epidemiol Biomarkers Prev 7: 1091-1100, 1998.

252. Shapiro TA, Fahey JW, Wade KL, Stephenson KK, and Talalay P. Chemoprotective Glucosinolates and Isothiocyanates of Broccoli Sprouts: metabolism and Excretion in Humans. Cancer Epidemiol Biomarkers Prev 10: 501-508, 2001.

253. Shen G, Khor TO, Hu R, Yu S, Nair S, Ho CT, Reddy BS, Huang MT, Newmark HL, and Kong AN. Chemoprevention of familial adenomatous polyposis by natural dietary compounds sulforaphane and dibenzoylmethane alone and in combination in ApcMin/ + mouse. Cancer Res 67: 9937-9944, 2007.

254. Shen G, Xu C, Chen C, Hebbar V, and Kong A-NT. p53independent $\mathrm{G} 1$ cell cycle arrest of human colon carcinoma cells HT-29 by sulforaphane is associated with induction of p21CIP1 and inhibition of expression of cyclin D1. Cancer Chemother Pharmacol 57: 317-327, 2006.

255. Silverman DT, Swanson CA, Gridley G, Wacholder S, Greenberg RS, Brown LM, Hayes RB, Swanson GM, Schoenberg JB, Pottern LM, Schwartz AG, Fraumeni JF, Jr., and Hoover RN. Dietary and nutritional factors and pancreatic cancer: a case-control study based on direct interviews. J Natl Cancer Inst 90: 1710-1719, 1998.

256. Singh SK, Clarke ID, Terasaki M, Bonn VE, Hawkins C, Squire J, and Dirks PB. Identification of a cancer stem 
cell in human brain tumors. Cancer Res 63: 5821-5828, 2003.

257. Singh SV, Herman-Antosiewicz A, Singh AV, Lew KL, Srivastava SK, Kamath R, Brown KD, Zhang L, and Baskaran R. Sulforaphane-induced G2/M phase cell cycle arrest involves checkpoint kinase 2-mediated phosphorylation of cell division cycle 25C. J Biol Chem 279: 2581325822, 2004.

258. Singh SV, Srivastava SK, Choi S, Lew KL, Antosiewicz J, Xiao D, Zeng Y, Watkins SC, Johnson CS, and Trump DL. Sulforaphane-induced cell death in human prostate cancer cells is initiated by reactive oxygen species. $J$ Biol Chem 280: 19911-19924, 2005.

259. Singletary K and MacDonald C. Inhibition of benzo[a]pyrene- and 1,6-dinitropyrene-DNA adduct formation in human mammary epithelial cells bydibenzoylmethane and sulforaphane. Cancer Lett 155: 47-54, 2000.

260. Slaby O, Sachlova M, Brezkova V, Hezova R, Kovarikova A, Bischofová S, Sevcikova S, Bienertova-Vasku J, Vasku A, Svoboda M, and Vyzula R. Identification of MicroRNAs regulated by isothiocyanates and association of polymorphisms inside their target sites with risk of sporadic colorectal cancer. Nutr Cancer 65: 247-254, 2013.

261. Slaby O, Svoboda M, Michalek J, and Vyzula R. MicroRNAs in colorectal cancer: translation of molecular biology into clinical application. Mol Cancer 8: 1476-4598, 2009.

262. Smith-Warner SA, Spiegelman D, Yaun SS, Adami HO, Beeson WL, and van den Brandt PA, Folsom AR, Fraser GE, Freudenheim JL, Goldbohm RA, Graham S, Miller AB, Potter JD, Rohan TE, Speizer FE, Toniolo P, Willett WC, Wolk A, Zeleniuch-Jacquotte A, and Hunter DJ. Intake of fruits and vegetables and risk of breast cancer: a pooled analysis of cohort studies. Jama 285: 769-776, 2001.

263. Smith-Warner SA, Spiegelman D, Yaun SS, Albanes D, Beeson WL, van den Brandt PA, Feskanich D, Folsom AR, Fraser GE, Freudenheim JL, Giovannucci E, Goldbohm RA, Graham S, Kushi LH, Miller AB, Pietinen P, Rohan TE, Speizer FE, Willett WC, and Hunter DJ. Fruits, vegetables and lung cancer: a pooled analysis of cohort studies. Int J Cancer 107: 1001-1011, 2003.

264. Sønderby IE, Burow M, Rowe HC, Kliebenstein DJ, and Halkier BA. A Complex Interplay of Three R2R3 MYB Transcription Factors Determines the Profile of Aliphatic Glucosinolates in Arabidopsis. Plant Physiol 153: 348363, 2010.

265. Speizer FE, Colditz GA, Hunter DJ, Rosner B, and Hennekens C. Prospective study of smoking, antioxidant intake, and lung cancer in middle-aged women (USA). Cancer Causes Control 10: 475-482, 1999.

266. Spitz MR, Duphorne CM, Detry MA, Pillow PC, Amos CI, Lei L, Andrade Md, Gu X, Hong WK, and Wu X. Dietary Intake of Isothiocyanates: evidence of a Joint Effect with Glutathione S-Transferase Polymorphisms in Lung Cancer Risk. Cancer Epidemiol Biomarkers Prev 9: 1017-1020, 2000.

267. Srivastava RK, Tang SN, Zhu W, Meeker D, and Shankar S. Sulforaphane synergizes with quercetin to inhibit selfrenewal capacity of pancreatic cancer stem cells. Front Biosci 3: 515-528, 2011.

268. Steck SE, Gaudet MM, Britton JA, Teitelbaum SL, Terry MB, Neugut AI, Santella RM, and Gammon MD. Interactions among GSTM1, GSTT1 and GSTP1 polymorphisms, cruciferous vegetable intake and breast cancer risk. Carcinogenesis 28: 1954-1959, 2007.
269. Steinbrecher A, Nimptsch K, Husing A, Rohrmann S, and Linseisen J. Dietary glucosinolate intake and risk of prostate cancer in the EPIC-Heidelberg cohort study. Int $J$ Cancer 125: 2179-2186, 2009.

270. Steinmetz KA, Kushi LH, Bostick RM, Folsom AR, and Potter JD. Vegetables, fruit, and colon cancer in the Iowa Women's Health Study. Am J Epidemiol 139: 1-15, 1994.

271. Steinmetz KA, Potter JD, and Folsom AR. Vegetables, fruit, and lung cancer in the Iowa Women's Health Study. Cancer Res 53: 536-543, 1993.

272. Strange RC, Spiteri MA, Ramachandran S, and Fryer AA. Glutathione-S-transferase family of enzymes. Mutat Res 482: 21-26, 2001.

273. Su Z-Y, Zhang C, Lee JH, Shu L, Wu T-Y, Khor TO, Conney AH, Lu Y-P, and Kong A-NT. Requirement and Epigenetics Reprogramming of Nrf2 in Suppression of Tumor Promoter TPA-Induced Mouse Skin Cell Transformation by Sulforaphane. Cancer Prev Res 7: 319-329, 2014.

274. Suppipat K, Park CS, Shen Y, Zhu X, and Lacorazza HD. Sulforaphane induces cell cycle arrest and apoptosis in acute lymphoblastic leukemia cells. PLoS One 7: 12, 2012.

275. Svehlikova V, Wang S, Jakubikova J, Williamson G, Mithen R, and Bao Y. Interactions between sulforaphane and apigenin in the induction of UGT1A1 and GSTA1 in CaCo-2 cells. Carcinogenesis 25: 1629-1637, 2004.

276. Takai M, Suido H, Tanaka T, Kotani M, Fujita A, Takeuchi A, Makino T, Sumikawa K, Origasa H, Tsuji K, and Nakashima M. [LDL-cholesterol-lowering effect of a mixed green vegetable and fruit beverage containing broccoli and cabbage in hypercholesterolemic subjects]. Rinsho Byori 51: 1073-1083, 2003.

277. Terry P, Wolk A, Persson I, and Magnusson C. Brassica vegetables and breast cancer risk. JAMA 285: 2975-2977, 2001.

278. The Angiosperm Phylogeny G. An update of the Angiosperm Phylogeny Group classification for the orders and families of flowering plants: APG III. Botanical $J$ Linn Soc 161: 105-121, 2009.

279. Thimmulappa RK, Mai KH, Srisuma S, and Kensler TW, Yamamoto M, and Biswal S. Identification of Nrf2regulated genes induced by the chemopreventive agent sulforaphane by oligonucleotide microarray. Cancer Res 62: 5196-5203, 2002.

280. Tili E, Croce CM, and Michaille JJ. miR-155: on the crosstalk between inflammation and cancer. Int Rev Immunol 28: 264-284, 2009.

281. Toneatto F, Hauser TP, Nielsen JK, and Ørgaard M. Genetic diversity and similarity in the Barbarea vulgaris complex (Brassicaceae). Nordic J Bot 30: 506-512, 2012.

282. Traka M, Gasper AV, Smith JA, Hawkey CJ, Bao Y, and Mithen RF. Transcriptome analysis of human colon Caco-2 cells exposed to sulforaphane. J Nutr 135: 1865-1872, 2005.

283. Vallejo F, Tomás-Barberán F, and García-Viguera C. Glucosinolates and vitamin $\mathrm{C}$ content in edible parts of broccoli florets after domestic cooking. Eur Food Res Technol 215: 310-316, 2002.

284. Veeranki OL, Bhattacharya A, Marshall JR, and Zhang Y. Organ-specific exposure and response to sulforaphane, a key chemopreventive ingredient in broccoli: implications for cancer prevention. Br J Nutr 109: 25-32, 2013.

285. Verhoeven DT, Goldbohm RA, van Poppel G, Verhagen $\mathrm{H}$, and van den Brandt PA. Epidemiological studies on 
brassica vegetables and cancer risk. Cancer Epidemiol Biomarkers Prev 5: 733-748, 1996.

286. Verkerk R, Schreiner M, Krumbein A, Ciska E, Holst B, Rowland I, De Schrijver R, Hansen M, Gerhäuser C, Mithen R, and Dekker M. Glucosinolates in Brassica vegetables: the influence of the food supply chain on intake, bioavailability and human health. Mol Nutr Food Res 53: S219-S219, 2009.

287. Vermeulen M, Klöpping-Ketelaars IWAA, van den Berg $\mathrm{R}$, and Vaes WHJ. Bioavailability and Kinetics of Sulforaphane in Humans after Consumption of Cooked versus Raw Broccoli. J Agric Food Chem 56: 10505-10509, 2008.

288. Voorrips LE, Goldbohm RA, van Poppel G, Sturmans F, Hermus RJ, and van den Brandt PA. Vegetable and fruit consumption and risks of colon and rectal cancer in a prospective cohort study: the Netherlands Cohort Study on Diet and Cancer. Am J Epidemiol 152: 1081-1092, 2000.

289. Voorrips LE, Goldbohm RA, Verhoeven DT, van Poppel GA, Sturmans F, Hermus RJ, and van den Brandt PA. Vegetable and fruit consumption and lung cancer risk in the Netherlands Cohort Study on diet and cancer. Cancer Causes Control 11: 101-115, 2000.

290. Vyas AR, Hahm E-R, Arlotti JA, Watkins S, Stolz DB, Desai D, Amin S, and Singh SV. Chemoprevention of Prostate Cancer by d,l-Sulforaphane Is Augmented by Pharmacological Inhibition of Autophagy. Cancer Res 73: 5985-5995, 2013.

291. Wang GC, Farnham M, and Jeffery EH. Impact of thermal processing on sulforaphane yield from broccoli (Brassica oleracea L. ssp. italica). J Agric Food Chem 60: 67436748, 2012.

292. Wang L, Giovannucci E, Hunter D, Neuberg D, Su L, and Christiani D. Dietary intake of Cruciferous vegetables, Glutathione S-transferase (GST) polymorphisms and lung cancer risk in a Caucasian population. Cancer Causes Control 15: 977-985, 2004.

293. Wang L, Liu D, Ahmed T, Chung FL, Conaway C, and Chiao JW. Targeting cell cycle machinery as a molecular mechanism of sulforaphane in prostate cancer prevention. Int J Oncol 24: 187-192, 2004.

294. Wang XF, Wu DM, Li BX, Lu YJ, and Yang BF. Synergistic inhibitory effect of sulforaphane and 5-fluorouracil in high and low metastasis cell lines of salivary gland adenoid cystic carcinoma. Phytother Res 23: 303-307, 2009.

295. Warwick SI, Sauder CA, and Al-Shehbaz IA. Phylogenetic relationships in the tribe Alysseae (Brassicaceae) based on nuclear ribosomal ITS DNA sequences. Botany 86: 315-336, 2008.

296. West DW, Slattery ML, Robison LM, Schuman KL, Ford MH, Mahoney AW, Lyon JL, and Sorensen AW. Dietary intake and colon cancer: sex- and anatomic site-specific associations. Am J Epidemiol 130: 883-894, 1989.

297. Wogan GN, Hecht SS, Felton JS, Conney AH, and Loeb LA. Environmental and chemical carcinogenesis. Semin Cancer Biol 14: 473-486, 2004.

298. Wong CP, Hsu A, Buchanan A, Palomera-Sanchez Z, Beaver LM, Houseman EA, Williams DE, Dashwood RH, and Ho E. Effects of sulforaphane and 3,3'-diindolylmethane on genome-wide promoter methylation in normal prostate epithelial cells and prostate cancer cells. PLoS One 9, e86787, 2014.

299. Woo KJ and Kwon TK. Sulforaphane suppresses lipopolysaccharide-induced cyclooxygenase-2 (COX-2) ex- pression through the modulation of multiple targets in COX-2 gene promoter. Int Immunopharmacol 7: 17761783, 2007.

300. Wu L, Noyan Ashraf MH, Facci M, Wang R, Paterson PG, Ferrie A, and Juurlink BH. Dietary approach to attenuate oxidative stress, hypertension, and inflammation in the cardiovascular system. Proc Natl Acad Sci U S A 101: 7094-7099, 2004.

301. Wu QJ, Yang Y, Vogtmann E, Wang J, Han LH, Li HL, and Xiang YB. Cruciferous vegetables intake and the risk of colorectal cancer: a meta-analysis of observational studies. Ann Oncol 24: 1079-1087, 2013.

302. Xu C, Shen G, Chen C, Gelinas C, and Kong AN. Suppression of NF-kappaB and NF-kappaB-regulated gene expression by sulforaphane and PEITC through IkappaBalpha, IKK pathway in human prostate cancer PC-3 cells. Oncogene 24: 4486-4495, 2005.

303. Xu C, Yuan X, Pan Z, Shen G, Kim J-H, Yu S, Khor TO, Li W, Ma J, and Kong A-NT. Mechanism of action of isothiocyanates: the induction of ARE-regulated genes is associated with activation of ERK and JNK and the phosphorylation and nuclear translocation of Nrf2. Mol Cancer Ther 5: 1918-1926, 2006.

304. Yang H, Wei W, Menconi M, and Hasselgren PO. Dexamethasone-induced protein degradation in cultured myotubes is p300/HAT dependent. Am J Physiol Regul Integr Comp Physiol 292: 14, 2007.

305. Ye L, Dinkova-Kostova AT, Wade KL, Zhang Y, Shapiro TA, and Talalay P. Quantitative determination of dithiocarbamates in human plasma, serum, erythrocytes and urine: pharmacokinetics of broccoli sprout isothiocyanates in humans. Clin Chim Acta 316: 43-53, 2002.

306. Ye L, Yu T, Li Y, Chen B, Zhang J, Wen Z, Zhang B, Zhou X, Li X, Li F, Cao W, and Huang Z. Sulforaphane enhances the ability of human retinal pigment epithelial cell against oxidative stress, and its effect on gene expression profile evaluated by microarray analysis. Oxid Med Cell Longev 413024: 25, 2013.

307. Youn HS, Kim YS, Park ZY, Kim SY, Choi NY, Joung SM, Seo JA, Lim KM, Kwak MK, Hwang DH, and Lee JY. Sulforaphane suppresses oligomerization of TLR4 in a thiol-dependent manner. J Immunol 184: 411-419, 2010.

308. Young TB and Wolf DA. Case-control study of proximal and distal colon cancer and diet in Wisconsin. Int $J$ Cancer 42: 167-175, 1988.

309. Yu S, Khor TO, Cheung K-L, Li W, Wu T-Y, Huang Y, Foster BA, Kan YW, and Kong A-N. Nrf2 Expression Is Regulated by Epigenetic Mechanisms in Prostate Cancer of TRAMP Mice. PLoS One 5: e8579, 2010.

310. Zhang C, Su Z-Y, Khor TO, Shu L, and Kong A-NT. Sulforaphane enhances Nrf2 expression in prostate cancer TRAMP C1 cells through epigenetic regulation. Biochem Pharmacol 85: 1398-1404, 2013.

311. Zhang H, Hao Y, Yang J, Zhou Y, Li J, Yin S, Sun C, Ma $\mathrm{M}$, Huang $\mathrm{Y}$, and $\mathrm{Xi}$ JJ. Genome-wide functional screening of miR-23b as a pleiotropic modulator suppressing cancer metastasis. Nat Commun 2: 554, 2011.

312. Zhang Y, Kensler TW, Cho CG, Posner GH, and Talalay P. Anticarcinogenic activities of sulforaphane and structurally related synthetic norbornyl isothiocyanates. Proc Natl Acad Sci U S A 91: 3147-3150, 1994.

313. Zhang $\mathrm{Y}$ and Talalay P. Anticarcinogenic Activities of Organic Isothiocyanates: chemistry and Mechanisms. Cancer Res 54: 1976s-1981s, 1994. 
314. Zhang Y, Talalay P, Cho CG, and Posner GH. A major inducer of anticarcinogenic protective enzymes from broccoli: isolation and elucidation of structure. Proc Natl Acad Sci U S A 89: 2399-2403, 1992.

315. Zhang YS, Kolm RH, Mannervik B, and Talalay P. Reversible Conjugation of Isothiocyanates with Glutathione Catalyzed by Human Glutathione Transferases. Biochem Biophys Res Commun 206: 748-755, 1995.

316. Zhong S, Wyllie AH, Barnes D, Wolf CR, and Spurr NK. Relationship between the GSTM1 genetic polymorphism and susceptibility to bladder, breast and colon cancer. Carcinogenesis 14: 1821-1824, 1993.

317. Zhou BB, Zhang H, Damelin M, Geles KG, Grindley JC, and Dirks PB. Tumour-initiating cells: challenges and opportunities for anticancer drug discovery. Nat Rev Drug Discov 8: 806-823, 2009.

318. Zhou C, Poulton EJ, Grün F, Bammler TK, Blumberg B, Thummel KE, and Eaton DL. The dietary isothiocyanate sulforaphane is an antagonist of the human steroid and xenobiotic nuclear receptor. Mol Pharmacol 71: 220-229, 2007.

319. Zhou W, Kallifatidis G, Baumann B, Rausch V, Mattern J, Gladkich J, Giese N, Moldenhauer G, Wirth T, Buchler MW, Salnikov AV, and Herr I. Dietary polyphenol quercetin targets pancreatic cancer stem cells. Int J Oncol 37: 551-561, 2010.

320. Zhu J, Ghosh A, Coyle EM, Lee J, Hahm E-R, Singh SV, and Sarkar SN. Differential Effects of Phenethyl Isothiocyanate and D,L-Sulforaphane on TLR3 Signaling. $J$ Immunol 190: 4400-4407, 2013.

Address correspondence to: Dr. Tom C. Karagiannis Epigenomic Medicine

Baker IDI Heart and Diabetes Institute The Alfred Medical Research and Education Precinct 75 Commercial Road Melbourne 3004

Australia

E-mail: tom.karagiannis@bakeridi.edu.au

Date of first submission to ARS Central, October 17, 2014; date of acceptance, November 3, 2014.

\section{Abbreviations Used}

$\mathrm{ADH}=$ aldehyde dehydrogenase

$\mathrm{AKR}=$ aldo-keto reductase

AP-1 = activator protein-1

$\mathrm{APG}=$ angiosperm phylogeny group

$\mathrm{APL}=$ acute promyelocytic leukemia

$\mathrm{AR}=$ androgen receptor

$\mathrm{ARE}=$ antioxidant response element

$\mathrm{BPH}-1=$ benign prostatic hyperplasia

$\mathrm{BQD}=\mathrm{p}$-benzoquinone dioxime

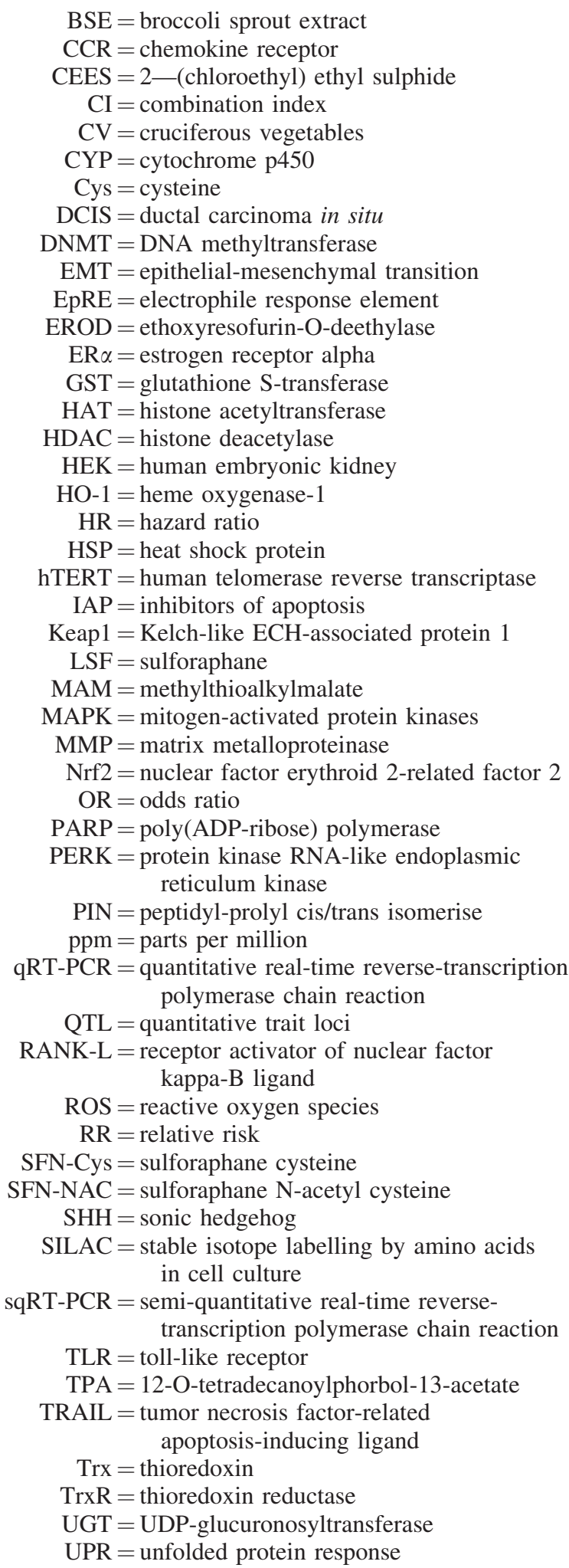

